E International

\title{
Measurement of National-Level Logistics Costs and Performance
}

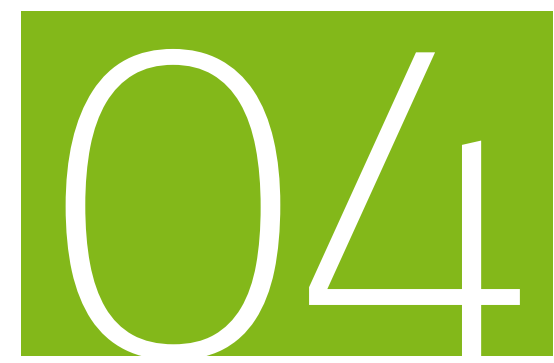

Discussion Paper 2012 • 04

Karri Rantasila* and Lauri Ojala

Turku School of Economics

at the University of Turku, Finland

* also affiliated to VTT,

Technical Research Centre of Finland 
This document was produced as a Background Paper for the 2012 Summit of the International Transport Forum, on Seamless Transport: Making Connections, held from 2-4 May 2012 in Leipzig, Germany. The views expressed in this document do not necessarily reflect those of the member countries of the International Transport Forum.

Further information about the International Transport Forum is available at www.internationaltransportforum.org 


\title{
MEASUREMENT OF NATIONAL-LEVEL \\ LOGISTICS COSTS AND PERFORMANCE
}

Discussion Paper No. 2012-4

\author{
Mr. Karri RANTASILA* \\ Professor Lauri OJALA \\ Turku School of Economics at the University of Turku, \\ Finland \\ * also affiliated to VTT, Technical Research Centre Finland \\ karri.rantasila@utu.fi \\ lauri.ojala@utu.fi
}

April 2012 



\section{INTERNATIONAL TRANSPORT FORUM}

The International Transport Forum at the OECD is an intergovernmental organisation with 53 member countries. It acts as a strategic think tank with the objective of helping shape the transport policy agenda on a global level and ensuring that it contributes to economic growth, environmental protection, social inclusion and the preservation of human life and well-being. The International Transport Forum organizes an annual summit of Ministers along with leading representatives from industry, civil society and academia.

The International Transport Forum was created under a Declaration issued by the Council of Ministers of the ECMT (European Conference of Ministers of Transport) at its Ministerial Session in May 2006 under the legal authority of the Protocol of the ECMT, signed in Brussels on 17 October 1953, and legal instruments of the OECD.

The members of the Forum are: Albania, Armenia, Australia, Austria, Azerbaijan, Belarus, Belgium, Bosnia-Herzegovina, Bulgaria, Canada, Chile, China, Croatia, the Czech Republic, Denmark, Estonia, Finland, France, FYROM, Georgia, Germany, Greece, Hungary, Iceland, India, Ireland, Italy, Japan, Korea, Latvia, Liechtenstein, Lithuania, Luxembourg, Malta, Mexico, Moldova, Montenegro, Netherlands, New Zealand, Norway, Poland, Portugal, Romania, Russia, Serbia, Slovakia, Slovenia, Spain, Sweden, Switzerland, Turkey, Ukraine, the United Kingdom and the United States.

The International Transport Forum's Research Centre gathers statistics and conducts cooperative research programmes addressing all modes of transport. Its findings are widely disseminated and support policymaking in member countries as well as contributing to the annual Summit.

\section{DISCUSSION PAPERS}

The International Transport Forum's Discussion Paper Series makes economic research, commissioned or carried out at its Research Centre, available to researchers and practitioners. The aim is to contribute to the understanding of the transport sector and to provide inputs to transport policy design. The Discussion Papers are not edited by the International Transport Forum and they reflect the author's opinions alone.

The Discussion Papers can be downloaded from:

www.internationaltransportforum.org/jtrc/DiscussionPapers/jtrcpapers.html

The International Transport Forum's website is at: www.internationaltransportforum.org or for further information on the Discussion Papers, please email: itf.contact@oecd.org 
Table of Contents

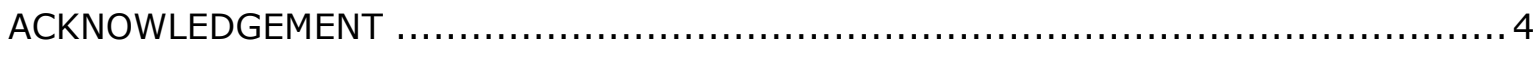

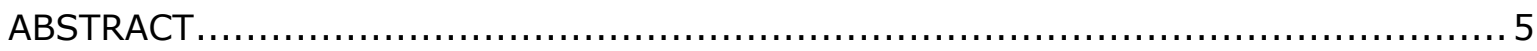

6

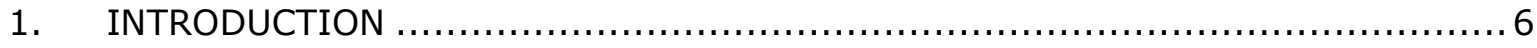

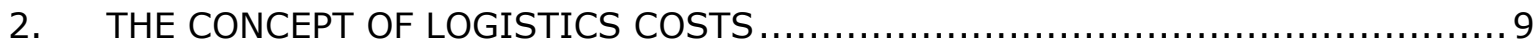

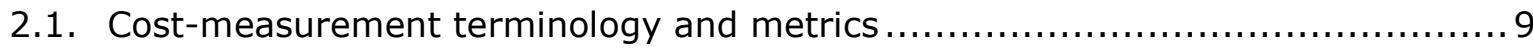

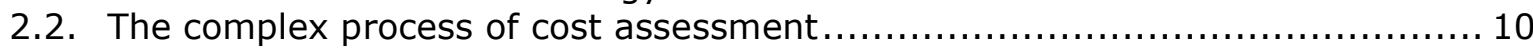

2.3. Methods of assessing logistics costs on the macro level........................... 12

2.4. Potential approaches to identifying logistics costs ................................ 13

2.5. The structure of logistics costs in the literature and in academic publications ... 14

3. AN OVERVIEW OF NATIONAL-LEVEL COST STUDIES......................... 16

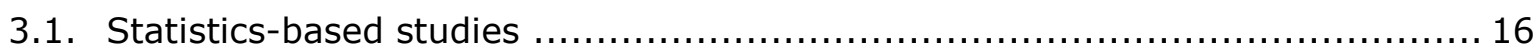

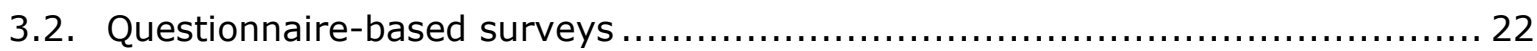

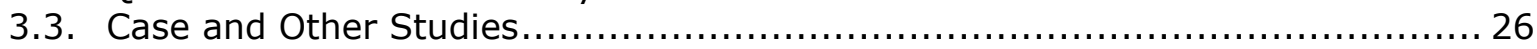

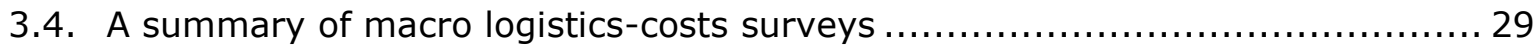

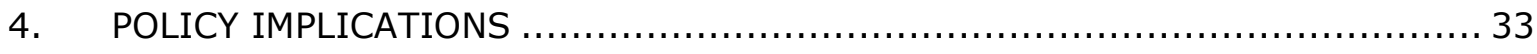

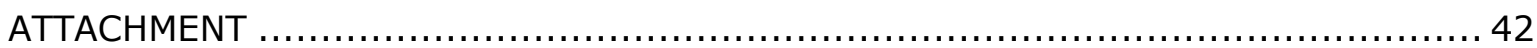




\section{ACKNOWLEDGEMENT}

This work is primarily based on research conducted at the Turku School of Economics. The research team led by Professor Ojala conducted four large national logistics surveys in 2006-2012 for the Ministry of Transport and Communications Finland, with up to 2,750 respondents in each. This line of research has been expanded in cooperation with The World Bank with a view to establishing a network of researchers and research institutions dealing with national-level logistics cost and performance measurement. This network-in-the-making is called the Logistics Performance International Observatory (LPIO). However, the conclusions in this Discussion Paper are solely those of the authors. 


\begin{abstract}
It is necessary to understand logistics performance at the country level in order to better evaluate and target Trade and Transport Facilitation (TTF) policy efforts over time and across countries. Lower costs for logistics reduce the cost of delivering products, thereby encouraging sales, increasing trade, opening new markets and generally encouraging business. Performance evaluation also helps to improve the efficiency of supply chains and the functioning of related infrastructures, services, procedures and regulation.

A sound and comprehensive set of national-level performance indicators is critical for high-level policy dialogue, preparation and implementation. Policymakers need a better understanding of:

i) The level of logistics costs in absolute terms and relative to other costs;

ii) The main drivers of logistics costs;

iii) How costs and deficiencies in performance affect certain sectors in the economy.

Existing cross-country comparisons - such as the World Bank's Logistics Performance Index - meet this demand only in part. Separate national surveys aimed at filling this knowledge gap have been carried out in High Income Countries such as Germany, France, Switzerland and Finland. Attempts to aggregate logistics costs using national accounts data have also been made in the United States, Canada, Sweden and Norway, for example, as well as in Brazil, Thailand and South Africa. There have been only sporadic efforts in Low Income Countries, mainly coordinated by the World Bank. Thus far these activities have proceeded in isolation, making it difficult to compare the findings. Hence, there is an obvious need to take stock of the existing studies and the methods applied in order to better understand the nature of the data they provide.

National-level surveys often cover also other facets of logistics in addition to costs, such as development needs, level of outsourcing, and some other Key Performance Indicators (KPI's). However, the treatment of logistics costs tends to lack coherent terminology and methodology in the data collection and analysis. Existing nationalaccounts-based models are still mostly "black boxes", making replication and the adoption of best practices difficult in other settings, let alone in developing countries. The qualitative approach is predominant in TTF case studies conducted in Low Income and Least Developed Countries.
\end{abstract}

This Discussion Paper presents and categorizes available national-level assessments of logistics costs, including the methods applied and comprising:

(1) Survey instruments based on primary data, and their results;

(2) Models of logistics costs based on national accounts and other relevant data. 


\section{INTRODUCTION}

Logistics plays a vital role in economic systems and in everyday life. Given the significant cut back in manufacturing and labour costs, reducing logistics costs has become an increasingly important task for managers. On account of the complex supply chains and globalization, the cost of logistics operations could comprise as much as half the value of general commodities. However, technological development offers new costcutting opportunities. (Dianwei 2006, 591)

According to Bowersox, Rodrigues \& Calantone (2005), global logistics costs in the year 2002 were estimated at USD 6,732 billion, and corresponded to 13.8 per cent of the world's GDP in 2002. (Bowersox et al. 2005, 9-10)

The level of logistics costs is heavily dependent on the industry, but in general tends to be high in logistics-intensive operations such as food, metal, chemical and paper manufacturing (Memedovic et al. 2008; Farahani, Asgari \& Davarzani 2009, 59).

The importance of lowering logistics costs has also been acknowledged on national, regional and global levels. These costs are significant and affect the competitiveness of nations (UN ESCAP 2002), as well as national-level policymaking, infrastructure development and other investments (Farahani et. al 2009, 58).

Several regional studies have also identified logistics costs as one of the major drivers affecting competitiveness; see, for example, Guasch and Kogan (2006). Examples on Latin America include Barbero (2010) and Guerrero, Lucenti and Galarza (2010).

Relying partly on findings from national logistics surveys conducted since 1990, the Finnish Government, for example, has included the goals of improving logistics competitiveness and reducing the costs in its programme (Finnish Governmental Programme 2007, 38).

Despite their significance, logistics costs are not directly included in any of the indicators developed for ranking countries on a global scale (Farahani et al. 2009, 60). The closest attempts include the Global Competitiveness Index (GCI) and the Logistics Performance Index (LPI). The GCI is under development at the World Economic Forum, and ranks countries' competitiveness based on 12 categories including infrastructure and technology, for example (Schwab 2011, 4-8). The widely used LPI, published by the World Bank Group, measures the current logistics environment in six areas: customs, infrastructure, international shipments, logistics quality and competence, tracking \& tracing and timeliness (see Figure 9). (Arvis, Mustra, Panzer, Ojala \& Naula 2007; Hollweg \& Wong 2009, 26; Behar, Manners \& Nelson 2011, 8; Arvis et al. 2010)

There is a relationship between a country's LPI ranking and its level of logistics costs: countries with a low LPI score tend to have high costs. In particular, socalled induced costs (related to non-delivery or the avoidance of non-delivery and 
storage) tend to be low in countries with a high LPI score, and direct costs (freight and other shipment-related costs) tend to decrease until the LPI score reaches a value of around 3.3 (Figure 1).

Figure 1. The Relationship between the LPI and the Level of Logistics Costs

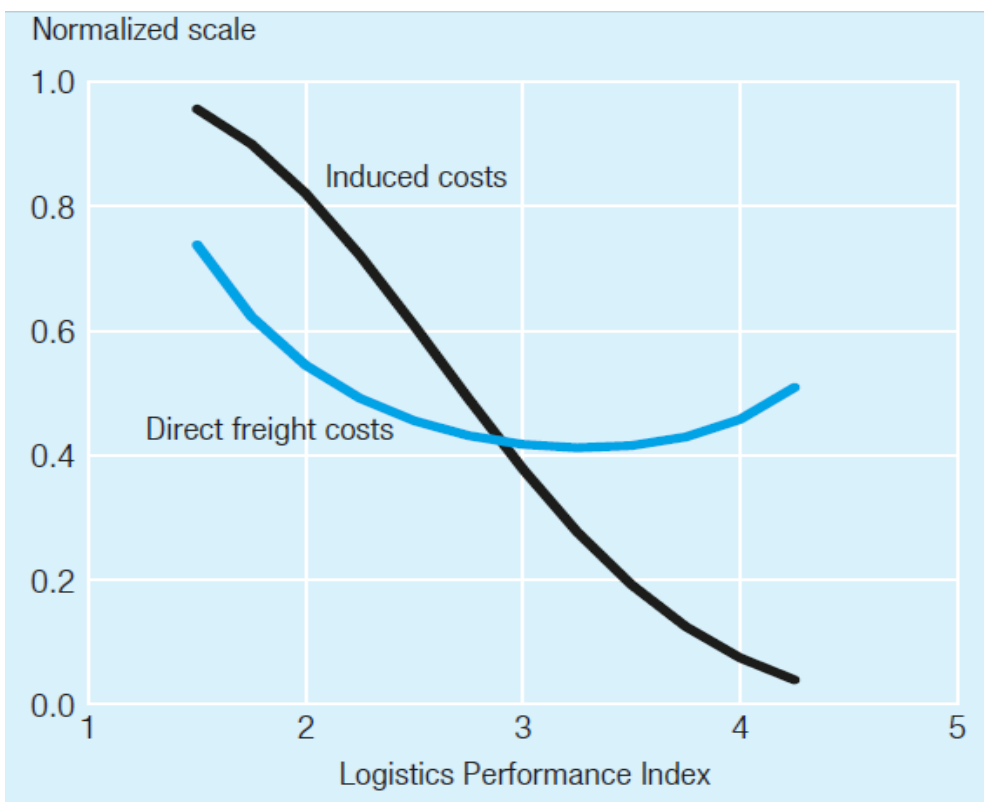

Source: Arvis, Mustra, Panzer, Ojala \& Naula 2007

Complementing the work of global organizations, many countries and research institutions conduct macro-level studies on logistics costs. One major challenge prevails with the results of these studies, however: neither the definitions nor the research methods are unified, thus the results are not comparable. If a unified and reliable method of measuring costs on the macro level could be developed, the results would provide a proper indicator for evaluating and monitoring logistics performance on the global, national and industry level.

The purpose of this discussion paper is to give an overview of the current state of research on the macro level, which is an issue that has not been covered adequately in the literature or the academic discussion.

Several authors point out that, despite its high importance, the question of national logistics costs is not properly addressed in the literature, and the definition remains incoherent (Farahani et al. 2009, 60 and Dianwei 2006, 592).

Furthermore, Straube \& Pfohl (2008) conclude that the cost components are not sufficiently standardized, both in the real world and on the scientific front. They also point to the conspicuous fact that some logistics professionals cannot even name all the relevant cost components. (Straube \& Pfohl 2008, 48-49)

Havenga $(2010,476)$ also states, given that a more efficient logistics system is the key to sustainable economic growth, it is a macroeconomic imperative to track the major cost components. 
The lack of comprehensive data on logistics costs, except in case studies of individual firms or shipments, was also cited by Brewer, Button \& Hensher $(2001,510)$. In view of the lack of an inventory of previously conducted research on national-level logistics costs, the aim of this paper is to provide information on what has been done and by whom, where and on what methodological basis, and what results have been arrived at.

There are many qualitative performance indicators that are important both at micro and macro level. Indeed, logistics management in firms is essentially managing multiple trade-offs between cost, time and service quality. However, the discussion of these goes beyond the scope of this paper. For a comprehensive review of performance indicators in logistics service provision, see for example: Krauth, Moonen, Popova and Schut (2005).

Chapter 2 discusses the concept of logistics costs and performance, and their measurement. Chapter 3 presents three main approaches to measuring macro costs (statistics-based, surveys and case/other studies), and briefly introduces previous studies on the subject: the results of the studies are presented in the attachment. Chapter 4 delves into the policy implications. 


\section{THE CONCEPT OF LOGISTICS COSTS}

\subsection{Cost-measurement terminology and metrics}

In general, the metrics and methods used for measuring logistics costs in firms (on the micro level) do not necessarily provide sufficient information for macro- or nationallevel estimation. The main reason for this is that firms collect information primarily to serve internal (e.g., cost accounting and process development) and external (e.g., bookkeeping and taxation) accounting needs.

Logistics Cost Survey 2006, conducted by Supply Chain Digest, canvassed the opinions of 247 respondents concerning the primary metric of logistics costs. Around 40 per cent of them used the percentage of sales, 25 per cent preferred absolute costs, and the remaining 35 per cent based their measurement on weight, sales unit or activity (SCD - Logistics Cost Survey 2006). However, these results concern the metrics utilized in firms, and cannot be directly applied to a macro context. Three types of metric stand out when costs are measured on the macro level (Rantasila 2010):

- Percentage of (aggregated) sales or turnover;

- Percentage comparison with the GDP level;

- Absolute costs ${ }^{1}$.

Some studies disclose logistics costs as a percentage of sales or turnover. As defined by the Organisation for Economic Co-operation and Development (OECD), both carry the same meaning, except for some minor differences concerning the inclusion or exclusion of value added tax (VAT). Turnover is defined as the total amount invoiced by the observation unit during the reference period, whereas sales comprise operating revenues less rebates, discount, returns and sales taxes on consumers (OECD Statistics 1; OECD Statistics 2).

Many studies express logistics costs as a percentage of the gross domestic product (GDP), which measures the value of all final goods and services as well as of exports generated in a certain area during the observation period. Regardless of its explanatory competence, GDP can be combined in three different ways (e.g., by summing the final uses of goods and services) (OECD Economics Department). In terms of measuring national logistics costs, it seems that regional costs are usually compared to the level of (regional) GDP (Feng \& Guijun 2008, 626; Li \& Tang 2010, 61).

1. The currency exchange rates referred to in this paper are derived from the European Central Bank database, indicating the exchange rate on the first weekday of January 
The third practice is to use the level of absolute costs. The challenge here lies in the lack of magnitude comparability between countries. If ratios are preferred, the question remains whether there is a difference between the percentage of turnover and the percentage of GDP. The difference between the two metrics relates to whether or not the value of exports is included. GDP excludes exports, but it can be assumed that firms include them in their turnover when assessing their logistics costs as a percentage of this figure. Given the complexity of converting these metrics into a commensurable form, this paper primarily presents results as a percentage of GDP, and if that is not possible, as a percentage of turnover. This is acceptable given that there are very limited possibilities of converting these into the same form, and the anticipated difference in results would be relatively minor. (International Monetary Fund, World Economic Outlook)

Three main approaches to measuring macro logistics costs have been identified (Rantasila 2010):

i) Statistics based;

ii) Survey based;

iii) Case studies.

These are discussed in more detail in Chapter 2.3 and Chapter 3.

\subsection{The complex process of cost assessment}

The calculation of logistics costs is complex even on the micro level, and in the national context very few attempts have been made. The issue has also received scant coverage in the research literature, and authors who do discuss it typically refer to the complexity (Wajszczuk \& Wielicki 2004, 196; Dianwei 2006, 592; Straube \& Pfohl 2008, 48-49; Farahani et al. 2009, 60; Havenga 2010, 476;).

Logistics activities are, indeed, complex and comprise many different processes. Additional challenges include difficulties related to collecting transparent information about these processes, and calculating the depreciation of all the property and equipment involved in the activities. (Farahani et al. 2009,60)

Micro-level aspects such as the firm's strategies and operational choices further complicate the measuring of macro-level logistics costs. These choices may create inhibitors to cost transparency, which could lead to deficient information, too narrow a view of cost management, or differences in allocations of overhead costs, for example. (Pohlen, Klammer \& Cokins 2009, 22-23; 30)

One choice firms make that significantly affects the perceived cost of logistics is whether or not to outsource the operations or to keep them in-house. The outsourcing of logistics functions is becoming increasingly prevalent, the current outsourcing rate of domestic transportation in Europe, for example, being 85 per cent, whereas for international transportation and warehousing it is 81 and 71 per cent, respectively. (Langley 2008, 13) In terms of measuring logistics costs, it is a matter of some importance whether or not the costs of outsourcing are perceived as being attributable to logistics. Furthermore, if the outsourcing contract bundles several functions, the cost of each one may be hard to assess. 
Another essential question concerns how the focal company arranges its inbound and outbound logistics, which defines the functions the costs of which are covered by the company. One way of identifying the company's share of the costs is to scrutinize the terms of delivery (incoterms). For example, if the company purchases its raw material ex works (EXW) and delivers its products duty paid (DDP) it may seem to incur higher logistics costs than a company that arranges its deliveries differently. Figure 2 illustrates the effect of the outsourcing level and terms of delivery on the probability of including all relevant logistics costs in the measurements.

Figure 2. The Impact of Incoterms on Logistics Costs

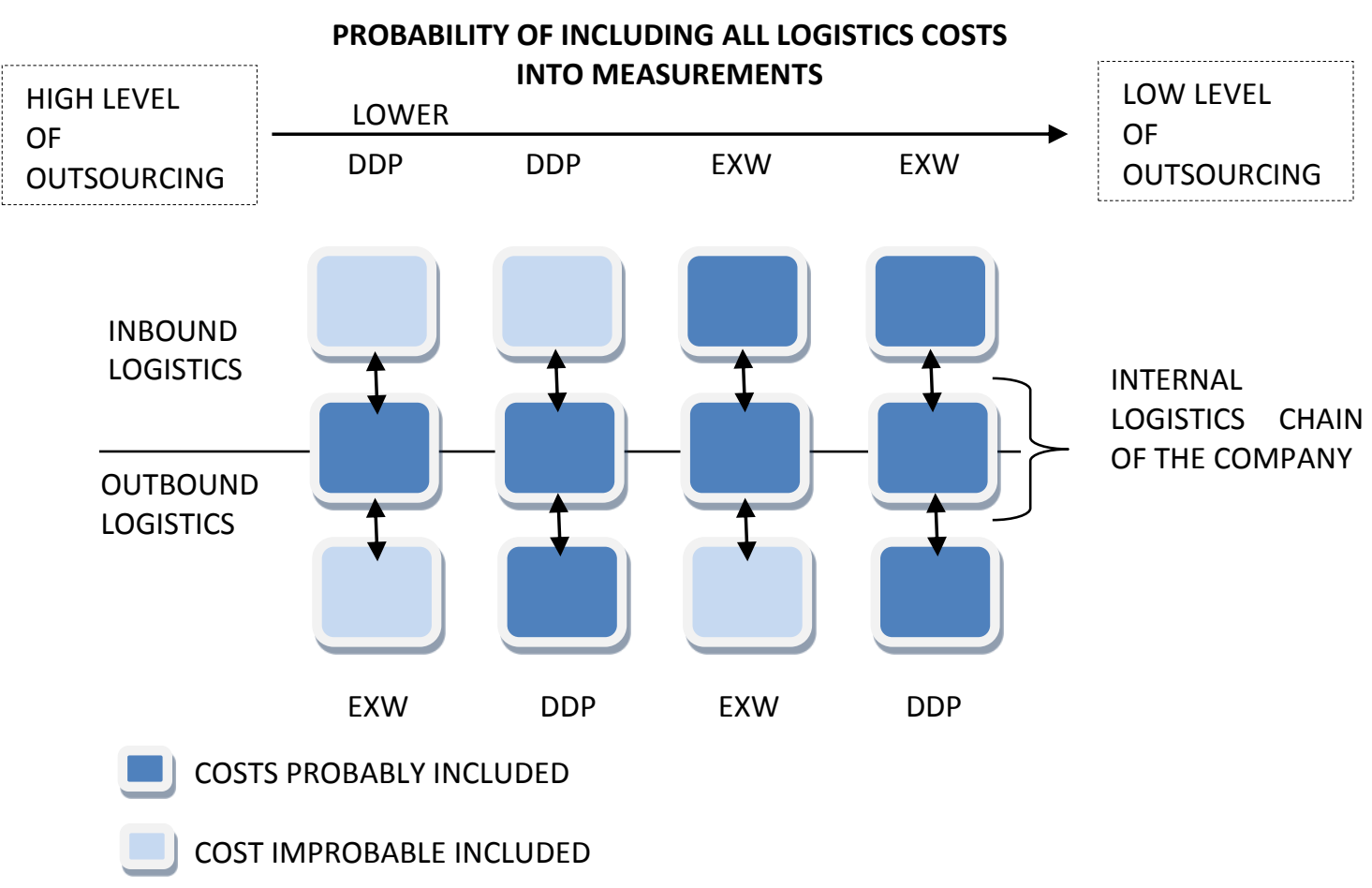

Source: partly adapted from Pohlen et al. 2009, 14; 29

The lower the level of outsourcing, the higher is the probability that all relevant logistics costs will be counted in. The same applies to different combinations of Incoterms, of which only extremity combinations are presented in the figure. Even if the problems of measuring logistics costs in the micro and macro contexts vary rather significantly, there is a strong connection between the two. Given the considerable differences in costing tools and methods (Pohlen et al. 2009, 12; 18-20), it could be assumed that this also affects the results of macro-level cost assessments based on survey methods.

A further complication with macro-level cost measurements relates to the availability and reliability of data. There are certain specific problems with all methods (statistics-based, survey-based and case studies) used in macro-level assessments. Generally, statistics play a vital role, especially when the cost estimates are based on modelling or case-based methods. In the case of surveys, the reliability is reflected in the sample size, the sampling techniques and the clarity of the questionnaire. 


\subsection{Methods of assessing logistics costs on the macro level}

Macro-level studies utilize various methods and tools depending on data availability and the reliability of statistical sources (e.g., macroeconomic statistics), among other things. If the appropriate statistical data is not available direct sampling can be used and information gathered in questionnaires and interviews, for example.

Three dominant methodological approaches to the study of logistics costs have been identified. The first is to collect empirical data directly from respondents, usually via questionnaires: these studies are referred to as surveys here.

The second is to combine existing data from different statistical sources (referred to as statistics-based studies here): Ojala $(1992,17)$ identifies three alternatives econometric modelling, analytic modelling and simulation.

When measuring logistics costs, national-level surveys rely almost exclusively on self-reported data collected from shippers, or logistics users. As exemplified in Figure 3, the statistics-based studies tend to rely on (statistical) data from the transport sector, or logistics providers. In addition to the choice of method, also the differing sources of data complicate the comparability of results across studies.

Figure 3. Examples of national-level studies on logistics costs using questionnaire-based or statistics-based approaches, and the type of data used in these.

\begin{tabular}{|c|c|c|}
\cline { 2 - 3 } $\begin{array}{l}\text { Questionnaire- } \\
\text { based survey } \\
\text { (Ch. 3.2.) }\end{array}$ & $\begin{array}{c}\text { Finland } \\
\text { Germany (BVL) } \\
\text { Switzerland } \\
\text { Thailand }\end{array}$ \\
\cline { 2 - 3 } $\begin{array}{l}\text { Statistics-based } \\
\text { Studies (Ch. 3.1.) }\end{array}$ & $\begin{array}{c}\text { U.S. State of Logistics } \\
\text { South Africa } \\
\text { Brazil } \\
\text { Norway } \\
\text { Europe Top 100 }\end{array}$ & Sweden \\
\cline { 2 - 3 } & $\begin{array}{c}\text { Supply-side data } \\
\text { Logistics providers }\end{array}$ & $\begin{array}{c}\text { Demand side data } \\
\text { Logistics users }\end{array}$
\end{tabular}

Thirdly there is the case-study method (referred to as case studies in this paper), which is also used in a considerable amount of research on supply chain management (Seuring 2008, 135). Hansen \& Hovi (2008, I), for example, suggest similar classifications (national-accounting-based, opinion/question-based surveys and studies based on estimating costs). The qualitative approach is predominant in TTF case studies conducted in Low Income and Least Developed Countries, most of which have been prepared by The World Bank.

Even the measurement of costs on the macro level is multidimensional and complex. Heskett, Glaskowsky and Nicholas documented the first model for tackling this problem in 1973 (Farahani et al. 2009, 67; Bowersox, Calantone and Rodrigues 2003, 21). They projected total logistics costs as the sum of four types of activities: transportation, 
inventories, warehousing and order processing. The model has fostered the evolution of research on the measurement of logistics costs, the results of which include Delaney's model, which is used in CSCMP's Annual State of Logistics Reports, and the estimation method of measuring global logistics costs developed by Bowersox et al. between 1992 and 2003.

The Bowersox model is based on four pillars: total GDP, government-sector production, industrial-sector production and the total trade ratio. The first and fourth components are included in order to measure the size of individual economies. Calculation of the total trade ratio involves summing the imports and exports, and then dividing the result by the GDP of the respective country. Government-sector and industrial-sector production facilitate the calculation of expenditure on logistics activities such as transportation, inventories and warehousing. Bowersox and Calantone refined the method and introduced the Artificial Neural Network (ANN) model, which is based on collections of mathematical models that emulate biological nervous systems. The ANN input variables include geographical location, economic factors, income level, transport and country size. (Bowersox et al. 2003, 21-28; Farahani et al. 2009, 68-69)

\subsection{Potential approaches to identifying logistics costs}

In general, cost components directly related to the physical flow of goods are easily perceived as a part of total logistics costs, and are thus referred to in this paper as direct costs. Logistics processes also generate functional costs such as for administration, which is not confined to logistics activities. Identifying and measuring these costs is considerably more difficult than measuring direct costs.

Although the most appropriate method for determining costs varies depending on the type of industry, there are still some rather well established general identification techniques (Bhattacharyya 2005, 34). One option is to position them in a fourfold table according to certain dimensions: direct vs. indirect costs, and overhead costs vs. activityrelated costs (see Figure 10). This approach has been adopted, for example, in Finland's State of Logistics 2006, 2009, 2010 and 2012 surveys and in the 2000 study on the State of Logistics in the Baltic Sea Region (Naula et al. 2006, 17; Solakivi et al. 2009; 2010; and 2012; Ojala et al. 2007, 36; Harrison \& van Hoek 2002, 56).

Another way of systemizing logistics costs is through Transaction Cost Analysis (TCA). Transaction costs occur in any exchange of commodities or services, including transactions taking place within or between firms. In general, the concept refers to the costs of transacting under uncertainty and managing the risk of dependence and spillover in an inter-firm context (Visser 2007, 216). In the context of supply chain management, Williamson emphasizes the encompassing character of previous literature (Williamson 2008, 14).

Transaction costs fall into three main groups: information costs, negotiation costs and enforcement costs (Williamson 1981, 552-553; Hobbs 1996, 17). TCA is further based on four key factors affecting the costs of the entity: uncertainty (or informational asymmetry), bounded rationality, opportunism and asset specificity. Ojala, for example, used TCA to classify logistics costs $(1995,38-40)$ in analysing Finnish foreign trade firms' operations. The applicability of TCA to the systematization of logistics costs is one example of how well established economic theories can be applied to current problems. 


\subsection{The structure of logistics costs in the literature and in academic publications}

In order to compare and illustrate the overall level of logistics costs it is necessary to identify the main components of logistics activities. There is no exhaustive definition or standard covering the cost components (Farahani et al. 2009, 60; Hansen \& Hovi 2008, I).

Hansen \& Hovi made a serious effort to identify the components in their 2008 review of previous studies. The problem with this review was the restricted source material, which was mainly collected in Scandinavia (Hansen \& Hovi 2008, 25).

Smith \& Huber $(2005,14)$ took a different approach in their study of 1,068 Irish companies, in which they surveyed the components included in supply chain costs.

Most textbooks consider logistics costs from a cost-accounting perspective, which differs from the macro context. Many of them refer to the concept of total costs developed by Lambert, Grant, Stock and Ellram. Six main cost groups are identified: customer service (including customer service, parts/service support and return-goods handling), transport costs and warehousing (including warehousing, storage, plant and warehouse site selection), inventory-carrying costs (including inventory management, packaging and reverse logistics), lot-quantity costs (including materials handling and procurement), and order-processing and information-systems costs (including order processing, logistics communication, demand forecasting and planning). (Lambert, Grant, Stock \& Ellram 2006, 11-21)

The literature suggests several levels on which the components of logistics costs can be broken down, ranging from three broad levels to very narrow component ranges. Sople, for example, identified three levels: transportation, storage and inventories (Sople 2007, 8), whereas Rushton, Croucher and Baker include four cost components: transportation, inventory-carrying, storage/warehousing and administration costs. Herbert W Davis \& Company used this classification in 2005, for example, and ELA in 2004 (Rushton, Croucher \& Baker 2006, 10-13).

Ayers (2006) ended up with five components: purchased materials and the associated labour, transportation, warehousing, inventories, and packaging (Ayers 2006, 63). Examples of more detailed cost breakdowns include Bidgoli's seven components and Kivinen and Lukka's 12 (Kivinen \& Lukka 2004).

Scientific publications offer more information than text books regarding the level of logistics costs. Although many articles concentrate on specific issues such as measuring costs in a certain industry, the cost dimension is frequently discussed. The following academic publications engage in discussion about cost components:

- $\quad$ Banomyong \& Supatn 2011, 21-26: nine cost dimensions with a sample of 43 Thai SMEs;

- Creazza, Dallari \& Melacini 2010, 157: four categories of logistics costs; no data;

- Choi \& Lee2009, 83-87: three cost components with Chinese data; 
- Hansen \& Hovi 2008, 2-4: five cost components with data from other studies;

- Jensen 2007, 2-4: six cost components with no data;

- Dianwei 2006, 591-592: six components of logistics costs identified with data from earlier studies;

- Bowersox et al. 2005, 9: the ANN model with empirical evidences from 24 countries in five continents;

- $\quad$ Zeng and Rossetti 2003, 785-793: six cost components.

Comprehensive summaries of the cost-component breakdowns used in the literature are given in the Attachment (Table 4 and Table 5). 


\section{AN OVERVIEW OF NATIONAL-LEVEL COST STUDIES}

The primary classification used in this chapter distinguishes studies employing different research methods. The three main categories identified are statistics-based studies, surveys, and case and other studies. Statistics-based studies utilize statistical data, models and methods in deriving the level of logistics costs. Statistics may include national accounting figures, for example. The distinctive difference between case studies (which also may utilize statistics) and statistics-based studies is that in the former the model is well established and verified. Surveys utilize questionnaires to collect data from respondents. There is one significant difference in approach between statistics-based studies and surveys from the supply-chain perspective: whereas the approach to the problem in the former is usually from the supply side of the chain, surveys tend to be conducted among demand-side actors. Finally, case and other studies represent investigations based on case-study methodology and studies that cannot be categorized as statistics-based or surveys. Case studies tend to be used when sufficient statistics are not available and it is not possible to conduct a survey. Other studies include those employing mixed methods, and also those that do not clearly disclose the methods used. Some examples are provided for each category.

\subsection{Statistics-based studies}

\subsubsection{Applied trade policy study by Shepherd (2011)}

Shepherd's paper (2011) is perhaps the most recent cross-country study in this field. He examined the issue of measuring logistics costs from an applied trade policy research perspective, as well as identifying logistics-intensive sectors. He focuses on currently available data at the macro- and firm-levels. Data sources include national accounts, national input-output tables, the International Comparison Project, firm-level data, and production and trade data. Although the data exhibit a number of weaknesses compared with "custom" logistics costs data-notably in terms of sectoral definition-they nonetheless make it possible to conduct some preliminary empirical analysis that can inform future measurement efforts.

First, the paper finds that there is little systematic evidence of a link between the size of the logistics sector and economic outcomes, such as trade openness. Second, the relationship between the size of the logistics sector and logistics performance is nonmonotonic. Third, the size of the logistics sector only increases in per capita income up to a certain point, before the relationship turns negative.

These findings suggest that measures of sectoral size-such as logistics costs relative to GDP-may be of limited use to researchers and policymakers because they do not have an unambiguous interpretation in terms of performance or economic outcomes. Fourth, however, direct indicators of price and performance are more clearly related to economic outcomes, and have a more straightforward relation with per capita income. 
The emphasis going forward should therefore be on compiling data that capture logistics performance most accurately, rather than sector size.

Finally, the paper uses input-output data to identify logistics-intensive sectors, and finds suggestive evidence that improvements in logistics performance could lead to sectoral reallocations in favour of relatively heavy industries in developing countries, which is consistent with the goal of export diversification.

\subsubsection{Top 100 in European Transport and Logistics Services}

Klaus \& Kille $(2007,42)$ measured the total costs of the European business logistics system, and estimated that the total annual expenditure on logistics services in the European economy was EUR 930 bn. in 2010. This includes all freight transportation, storage, trans-shipment and order picking, all inventory-maintenance expenditure, order processing, planning, management and administration expenditure, covering both inhouse and outsourced logistics services.

Two partly overlapping methods were applied: 1 ) extrapolation based on roadtransport volumes, distances and freight types in Germany and 2) the calculation of logistics costs from national economic data on value-creating activities. An example of the latest results is provided in Figure 11. (Klaus \& Kille 2007, 42-46; Klaus, Kille \& Schwemmer 2011, 1)

\subsubsection{The CSCMP's Annual State of Logistics Report (USA)}

The Council of Supply Chain Management Professionals (CSCMP) publishes the Annual State of Logistics Report, which defines the current state of business logistics costs and the outlook for business logistics in the United States. The methodology used remains the same from year to year, making the results comparable.

The study presents logistics costs in three main components: inventory carrying, transportation and logistics administration (4\% of the total). There was an increase in logistics costs in 2010 from 7.8 per cent of GDP (USD 1,100 billion) in 2009 to 8.3 per cent (USD 1,211 billion). This was mainly attributable to a rise in transport and inventory-carrying costs. Figure 12 illustrates the development of absolute costs compared to costs as a percentage of GDP. (CSCMP's 20th Annual State of Logistics Report 2009, 1; Wilson 2011, 12-13)

The level of logistics costs has decreased fairly steadily as a percentage of the GDP, even if the absolute value has increased. This means that the economy has grown more quickly than logistics costs have increased, which also means that the development has been positive, at least from a logistics perspective.

\subsubsection{Canada/United States logistics analyses}

The methodology used in the reports is based on an in-house developed model giving a three-level breakdown of logistics costs classified as follows: internal costs, outsourced costs and inventory-carrying costs. This method is not completely unambiguous and differs from activity-based grouping, which is employed in many other studies. (Industry Canada - Logistics Cost and Agility Assessment Tool, 4-5; State of 
Logistics: The Canadian Report 2008, 2; SCM and KPI Analysis - A Canada / United States Perspective 2006, 24).

\subsubsection{State of Logistics Surveys for South Africa}

The Council for Scientific and Industrial Research (CSIR) has been publishing the Annual State of Logistics Survey for South Africa annually since 2004. All the editions employ the same modelling technique, starting with the computation of total logistics costs from product-specific data covering transportation mode, transported and stored tonnage, transportation distances and costs, transit times and the opportunity cost of time during the transport. (State of Logistics Survey for South Africa 2004, 4-9)

The model (Logistics Cost Model - LCM) reflects a bottom-up approach to computing the costs by aggregating the primary input elements (number of commodities produced) and the costs of carrying out additional activities (transport, storage and handling). (State of Logistics Survey for South Africa 2007, 14-15; State of Logistics Survey for South Africa 2010, 9). The model used in the South African study is based on the work of Jan Havenga (see e.g. Havenga 2007 and 2010).

Logistics costs for South Africa in 2010 totalled ZAR 323 bn., or 13.5 per cent of GDP. There was a decrease from 2007 and 2008, when total costs were 15.9 (2007) and 14.7 (2008) per cent, respectively. Figure 13 gives the level of each cost component (transportation, inventory carrying, storage \& ports, and management \& administration). (State of Logistics Survey for South Africa 2010, 18-19)

\subsubsection{Logistics Cost Statistics of the CFLP}

The China Federation of Logistics and Purchasing publishes the figures for China's logistics industry on a yearly basis based on data from the National Bureau of Statistics. The latest available figures give the situation in 2010, when total logistics costs increased by 16.7 per cent to 7.1 trillion Yuan (EUR 805 bn.). Nevertheless, the costs-to-GDP-ratio declined by 0.3 per cent to 17.8 per cent. Transportation ( 3.8 trillion Yuan) accounted for 54 per cent of the total costs, followed by storage costs of 2.4 trillion Yuan (33.9 per cent of the total). The last component, management costs ( 0.9 trillion Yuan), accounted for 12.1 per cent of the total. (CFLP 2010) The development of logistics costs in China is depicted in Figure 14.

\subsubsection{Studies of logistics markets in Switzerland}

According to a study conducted by St. Gallen University, the volume of Switzerland's logistics markets in 2009 was approximately CHF 34.4 bn., or 6.5 per cent of GDP (Figure 15). Four main cost components are identified in the latest study: transportation, handling, warehousing and other logistics costs. (Factsheet zur Logistikmarktstudie 2011: Volumen Logistikmarkt Schweiz; Stölzle, Hoffmann \& Gebert 2009, 146-149)

\subsubsection{The Logistical Strength of the Netherlands Study}

De logistieke kracht van Nederland 2009 was published for the second time in 2009, when total logistics costs were slightly over EUR 46 billion. The total costs are divided into five groups: transportation, warehousing, inventory-carrying, administrative and management/planning costs. (De Logistieke Kracht van Nederland 2009, 22-23) 
Transportation costs accounted for the biggest share of total costs at EUR 20.5 billion, or 43 per cent, followed by warehousing (EUR 11.5 bn.) and inventory-carrying (EUR 9.7 bn.) costs. The total expenditure on administrative and management/planning costs was close to five billion euro. (De Logistieke Kracht van Nederland 2009, 23)

\subsubsection{Logistics Report Thailand}

The Office of the National Economic and Social Development Board (NESDB) in Thailand has developed a model and database that has given an official account of Thailand's logistics since 2003. According to the latest report, published in 2009, the value of total logistics costs in 2008 was equivalent to 18.6 per cent of GDP (1.7 trillion Baht). Three cost components are identified: transportation, inventory holding and logistics administration. The development of costs per component is depicted in Figure 16 (Logistics Report 2007 Thailand, 1; Thailand Logistics Report 2008, 5)

\subsubsection{Macroeconomic logistics costs in the Republic of Korea}

The Korea Transport Institute (KOTI) estimates macroeconomic logistics costs in the Republic of Korea in terms of the following factors: transportation, inventory holding, packaging, stevedoring, information and administration. (KOTI 2010, 88-94) Figure 18 gives a more detailed description of the components and data sources.

The latest report, published in 2010, estimates the total logistics costs for the Republic of Korea in 2008 at 128.3 trillion Won (approximately EUR 69.6 bn.), which accounted for 12.5 per cent of the year's GDP (KOTI 2010, 34). Figure 17 depicts the development of logistics costs in Korea as a percentage of DGP with the respective cost structure.

\subsubsection{Logistics and trade competitiveness in Morocco}

La Logistique du Commerce et la Compétitivité du Maroc 2006 was a result of the cooperation between The World Bank and the Ministry of Transportation in Morocco. The study is based on previous research results, national statistics, national accounts, and discussions with actors in various industries, governmental bodies and both export and import organizations. An analysis was conducted in industries that are important for Morocco's economy, namely the automotive, electronics, textile and fruit/grocery industries. (La Logistique du Commerce et la Compétitivité du Maroc 2006, 5-6; 111)

The total logistics costs in Morocco were approximately 20 per cent of GDP. The cost components are categorized in accordance with the fourfold table discussed in Chapter 2.4, which differentiates between direct and indirect costs, as well as between production and overhead costs. (La Logistique du Commerce et la Compétitivité du Maroc 2006, 5; 19-20)

\subsubsection{Macro-level logistics in Sweden}

The aim of this study was to create a tool for measuring macro-level logistics based on national statistics. (Elger, Lundquist and Olander 2008, 7-9) The cost components are grouped in four categories: direct transportation, warehousing, inventory carrying and administration. Direct transportation costs comprise the summed costs of internally produced and bought (external) activities. Inventory-carrying costs, on the other hand, 
include interest of 25 per cent of the inventory value combined with warehousing costs, meaning the costs of warehousing premises and other costs related to them.

Administration costs comprise personnel and other overhead costs related to logistics activities. (Elger et al. 2008, 17; 19-23)

The absolute cost of logistics in 2005 was SEK 233.3 bn. (EUR 25.7 bn.), of which inventory-carrying costs accounted for the major share (Table 6). Transportation costs increased most between the years 1997 and 2005, reaching SEK 85.5 bn. in 2005.

\subsubsection{Summary}

Figure 4 shows the results of selected statistics-based studies. The geographical coverage of the study in question, as well as the year to which the data applies is indicated in each case.

Figure 4. Levels of Logistics Costs in Statistics-based Studies as a Percentage of GDP ( $* \%$ of sales)

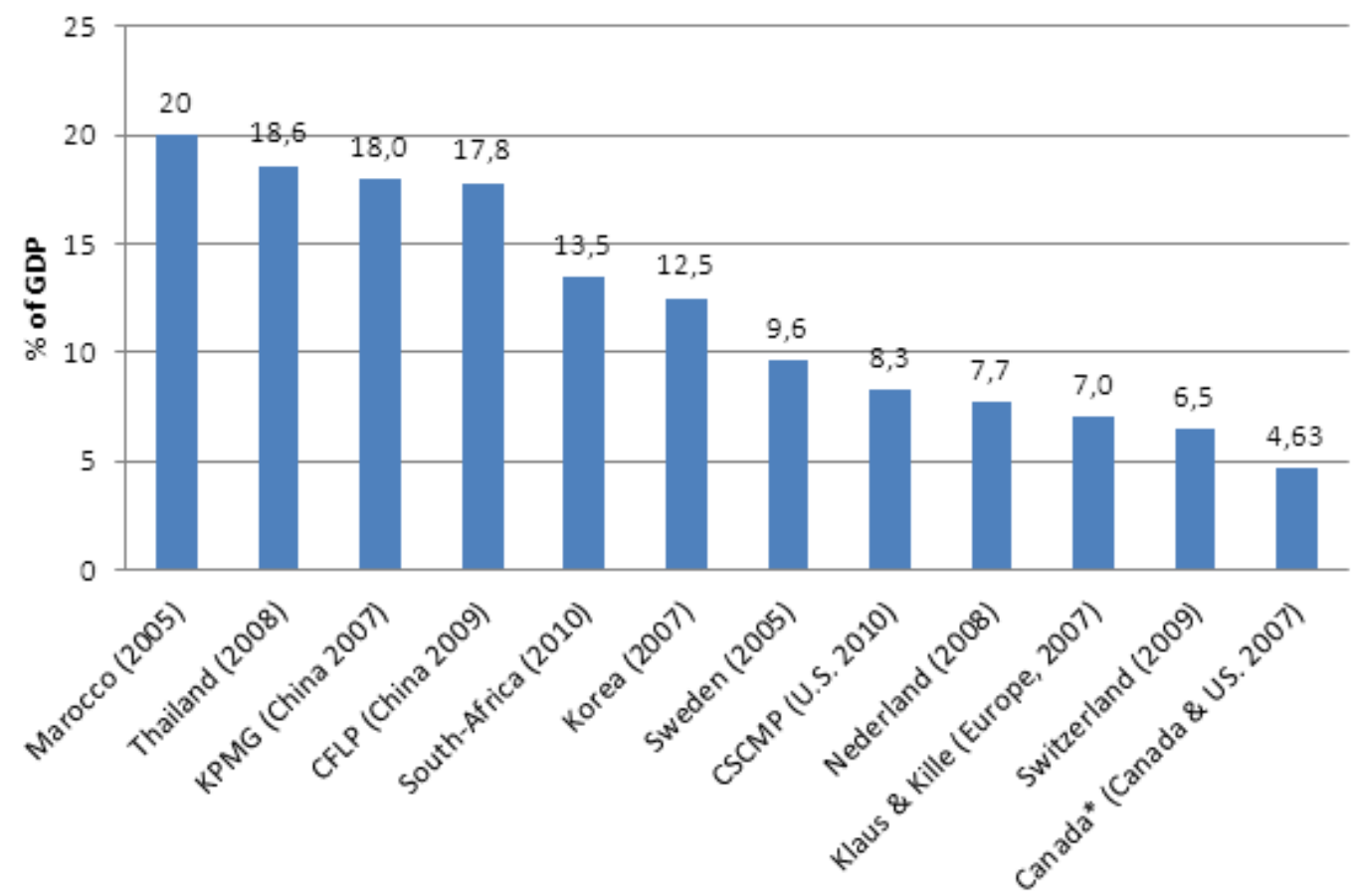

Sources: for references, see the Bibliography

As Figure 4 illustrates, the level of logistics costs varies rather widely among the studies conducted in different geographical areas. There also seems to be, as expected, a gap between Western economies and developing countries.

Table 1 specifies the cost components used in each study, and highlights some other aspects of logistics costs that came to light during the literature review. The results are presented in order of the year of publication. 
The table indicates whether the coverage is sole country (S) or multi-country (M), whether the cost components are broken down, and the year of the study. Furthermore, the level of logistics costs (also indicated with respect to the industry if possible), and the measurement scale (percentage of turnover or sales, or percentage of GDP) are quoted. The company-size classification applied and the areas covered are indicated at the bottom of the table.

Table 1. A Summary of Statistics-based Logistics Studies

\begin{tabular}{|c|c|c|c|c|c|c|c|c|c|c|c|c|c|}
\hline $\begin{array}{r}\text { Study } \\
\text { (year of publication) }\end{array}$ & 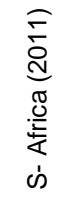 & $\begin{array}{l}\widehat{\bar{C}} \\
\hat{i} \\
\sum_{0}^{0} \\
0\end{array}$ & 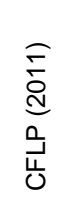 & 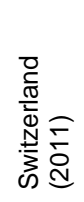 & 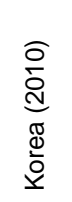 & 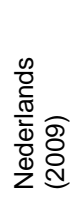 & 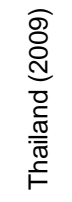 & 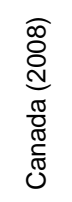 & 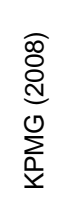 & 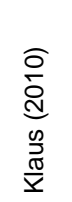 & 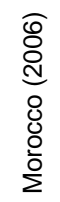 & 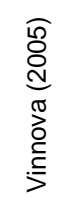 & 々 \\
\hline $\begin{array}{l}\text { Scope (Multi/Single } \\
\text { country) }\end{array}$ & $S$ & S & S & $S$ & S & $S$ & S & M & S & M & $S$ & $S$ & ర్ \\
\hline \multicolumn{14}{|c|}{ Cost components } \\
\hline Transportation & $\checkmark$ & $\checkmark$ & $\sqrt{9}$ & 9 & 9 & 9 & $\sqrt{ }$ & & $\checkmark$ & $\sqrt{ }$ & $\sqrt{7}$ & 9 & 11 \\
\hline Administration & 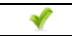 & $\checkmark$ & $\mathscr{q}$ & & $\checkmark$ & 9 & $\checkmark$ & & $\checkmark$ & 9 & 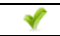 & 9 & 10 \\
\hline Inventory carrying & $\checkmark$ & $\sqrt{ }$ & & & $\checkmark$ & 9 & 9 & 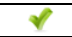 & & 9 & 9 & 9 & 9 \\
\hline Warehousing & 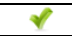 & & & $\checkmark$ & & 9 & & & $\checkmark$ & 9 & 9 & 9 & 7 \\
\hline Cargo handling & & & & $\checkmark$ & $\checkmark$ & & & & & & 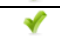 & & 3 \\
\hline Transport pack. & & & $\checkmark$ & & $\checkmark$ & & & & & & 9 & & 3 \\
\hline Communication & & & & & & & & & & & 9 & & 1 \\
\hline Customer service & & & & & & & & & & & 9 & & 1 \\
\hline Documentation & & & & & & & & & & & $\checkmark$ & & 1 \\
\hline Equipment & & & & & & & & & & & 9 & & 1 \\
\hline Information & & & & & $\checkmark$ & & & & & & & & 1 \\
\hline Insurance & & & & & & & & & & & 9 & & 1 \\
\hline Internal logistics costs & & & & & & & & $\checkmark$ & & & & & 1 \\
\hline Internal services & & & & & & & & & & & $\sqrt{9}$ & & 1 \\
\hline Obsolescence & & & & & & & & & & & 9 & & 1 \\
\hline $\begin{array}{l}\text { Outsourced logistics } \\
\text { costs }\end{array}$ & & & & & & & & $\checkmark$ & & & & & 1 \\
\hline Order processing & & & & & & & & & & 9 & & & 1 \\
\hline Other logistics & & & & $\checkmark$ & & & & & & & & & 1 \\
\hline Plan/management & & & & & & $\checkmark$ & & & & & & & 1 \\
\hline$R \& D$ & & & & & & & & & & & $\sqrt{9}$ & & 1 \\
\hline Shipper related & & $\checkmark$ & & & & & & & & & & & 1 \\
\hline \multicolumn{14}{|c|}{ Industry classification } \\
\hline Manufacturing & & & & & & & & 6.13 & & & & & \\
\hline Trade & & & & & & & & 3.13 & & & & & \\
\hline Total costs & $\checkmark$ & $\checkmark$ & $\checkmark$ & $\checkmark$ & $\checkmark$ & $\checkmark$ & $\checkmark$ & & $\checkmark$ & $\checkmark$ & 9 & $\checkmark$ & \\
\hline \multicolumn{14}{|c|}{ Time series (publications) } \\
\hline-1990 & & $\checkmark$ & & & & & & & & & & & \\
\hline 1991-1995 & & $\checkmark$ & & & & & & & & & & & \\
\hline $1996-2000$ & & $\checkmark$ & & & & & & & & & & & \\
\hline $2001-2005$ & $\checkmark$ & 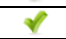 & & & & & & & & & & & \\
\hline 2006 & $\checkmark$ & $\checkmark$ & $\checkmark$ & & & & & $\checkmark$ & & & 9 & & \\
\hline 2007 & $\checkmark$ & $\checkmark$ & $\checkmark$ & & & $\checkmark$ & 9 & & & $\checkmark$ & & & \\
\hline 2008 & $\checkmark$ & $\checkmark$ & $\checkmark$ & & & & $\checkmark$ & $\checkmark$ & $\checkmark$ & & & $\checkmark$ & \\
\hline 2009 & $\checkmark$ & $\checkmark$ & $\checkmark$ & 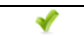 & & $\checkmark$ & 9 & & & & & & \\
\hline 2010 & $\checkmark$ & $\checkmark$ & $\checkmark$ & & $\checkmark$ & & & & & & & & \\
\hline 2011 & $\checkmark$ & $\checkmark$ & $\checkmark$ & $\checkmark$ & & & & & & $\checkmark$ & & & \\
\hline \multicolumn{14}{|c|}{ Scale of measurement and logistics cost in the most recent study } \\
\hline$\%$ of sales/turnover & & & & 3.6 & & & & $\checkmark$ & & & & & \\
\hline$\%$ of GDP & 13.5 & 8.3 & 17.8 & 6.5 & 12.5 & & 18.6 & & 18 & & 20 & 9.08 & \\
\hline $\begin{array}{l}\text { Absolute costs } \\
\text { (bn. euro) }\end{array}$ & 36.5 & 828 & 805 & 28.7 & 69.9 & 46 & 42.3 & & 370 & 930 & & 25.7 & \\
\hline
\end{tabular}




\subsection{Questionnaire-based surveys}

\subsubsection{The Davis Logistics Cost and Service Database}

The Davis Database is an on-going web-survey that allows firms to benchmark the levels of their logistics costs and services. Collecting data via an open web-based questionnaire may initially seem to be an unreliable method, but the questionnaire form is well structured, and the logistics cost components in particular are defined comprehensively. Respondents are asked to give the costs for primary and secondary transportation separately. Inventory-carrying costs are calculated by multiplying the average inventory of the previous fiscal year by 0.18 . However, even if the coverage of the survey is theoretically global, most respondents are located in developed countries, mainly the United States. (Davis Logistics Cost and Service Database; Davis Database Presentation 2009, 2; Davis Database Presentation 2010, 2)

The Davis Database reports costs as a percentage of sales, broken down on five levels. Total logistics costs of the average company in 2010 were 8.28 per cent of sales (8.48\% in 2009 and $9.28 \%$ in 2008). The five cost components are: transportation, warehousing, inventory carrying, customer service/order entry and administration. Figure 19 gives the average company costs per component in the three most recent studies. (Davis Database Presentation 2009, 6; Davis Database Presentation 2010, 9)

\subsubsection{GMA logistics surveys}

The latest logistics surveys conducted by the Grocery Manufacturers Association (GMA) are based on the opinions of logistics executives in member firms (i.e. firms in the grocery sector). The average total logistics costs declined from 6.9 per cent of sales in 2008 to 6.75 per cent in 2010. The components utilized include outbound customer transportation costs, intra-company transportation costs, distribution-centre costs, other logistics costs and management/overhead costs (Figure 20). (The GMA Logistics Study 2008, 5-11; The GMA 2010 Logistics Benchmark Report, 9-10)

\subsubsection{Surveys of the European Logistics Association}

The European Logistics Association (ELA) is a coalition of 30 national organizations covering most countries in Western and Central Europe (ELA homepage, About us). Logistics costs have decreased significantly from 12.1 per cent of sales (1987) to 7.3 per cent (2008). The decreasing trend seems to be stabilizing, and in recent years the cost of some components has even started to increase (Figure 21). (Supply-Chain-Excellence in der globalen Wirtschaftskrise 2009)

\subsubsection{Trends and Strategies in Logistics}

Straube and Pfohl (2008) collected data from 897 German-based and 155 EU-based firms for their book Trends and Strategies in Logistics. They identified six cost components: administration, value-added services, packaging, transport, inventory carrying and warehousing. (Straube \& Pfohl 2008, 46-49) 
Total logistics costs rose by 0.5 per cent (from $6.5 \%$ to $7.0 \%$ ) between 2005 and 2008 in the industrial sector, whereas in the trading sector they fell from 17.0 to 15.9 per cent (Figure 22). (Straube \& Pfohl 2008, 46-49)

\subsubsection{The State of Logistics in the Baltic Sea Region}

The State of Logistics in the Baltic Sea Region survey was part of the LogOn Baltic project, which was an initiative funded by the European Regional Development Fund. The total number of respondents in this survey-based study, published in 2007, was 1,234, which made it the largest available database in the region. (Ojala et al. 2007, 17-21)

Logistics costs were assessed for manufacturing and trading firms, broken down into five components: transportation, warehousing, inventory carrying, administration and all other logistics-related costs. Total costs, covering manufacturing and trading firms in all areas, varied from 16 (micro firms) to 11 (large firms) per cent of turnover (Figure 23). (Ojala et al. 2007, 35-37)

\subsubsection{The SCI Verkehr Logistikbarometer, Germany}

SCI Verkehr, an independent consultancy company focused on traffic economy and traffic engineering, publishes a monthly logistics barometer that analyses certain logistics indicators chosen by 200 managers in the transport and logistics sector (SCI Verkehr Logistikbarometer November 2009, 5; SCI Verkehr website). Even though the barometer does not directly identify the different elements or disclose the figures, it indicates the current trends in cost development (Figure 24).

\subsubsection{Finland State of Logistics surveys}

The Finland State of Logistics 2010 survey continues the series of Finnish surveys published in 1993, 1997, 2001, 2006 and 2009. With 1,812 respondents to the on-line questionnaire, this is the most comprehensive database in the world. (Solakivi et al. 2010, 3)

The six cost groups were derived from the fourfold systemization of logistics table: transportation, warehousing, inventory-carrying, administration, transport-packaging and other logistics-related costs. The latest edition, to be published in May 2012, includes packaging and transport costs. There was a decrease in total logistics costs in 2010 compared with previous reports (Figure 25). (Solakivi et al. 2010; 74)

\subsubsection{The Institute of Transport Economics, Norway survey}

The Institute of Transport Economics of Norway conducted a survey of logistics costs in Norwegian manufacturing and trade during the autumn of 2008, based on 525 responses. On average, logistics costs constituted 14.2 per cent of turnover in 2007, corresponding to 14.7 per cent of Norwegian mainland GDP. (Hovi \& Hansen 2010, i; Hansen \& Hovi 2010, 2) The seven-component cost distribution per industry employed in the study is presented in Figure 26. 


\subsubsection{The Norwegian Logistics Barometer}

Norsk Logistikkbarometer, as this survey is called in Norwegian, appeared for the first time in 2003, published by The Institute of Transport Economics (Transportøkonomisk institutt, TØI).

The reporting of the results varies depending on the year. The latest version categorizes costs in eight groups: depreciation, other indirect costs, packaging, obsolescence, administration, warehousing, transportation and tied capital. (Hansen \& Hovi 2008, 16; Norsk Logistikkbarometer results 2003; Norsk Logistikkbarometer 2009 results)

\subsubsection{The state of French logistics (ASLOG)}

The national logistics association ASLOG published the latest French logistics survey in 2010. The data is based on interviews in 346 French firms. Total logistics costs amounted to 11.9 per cent (2009) of turnover, which was higher than the 9.9 per cent in 2006 (Figure 27). The study classifies costs in three main groups: transportation, warehousing/inventory carrying and administration. The data for the 2010/2011 survey has been collected, but the results are not yet available on the association's website. (ASLOG - L'etat de l'art de la Logistique Française 2010)

\subsubsection{Colombia's National Logistics Survey}

The Latin America Logistics Center (LALC) published a Colombian logistics cost survey in 2008. The results, based on the figures provided by 322 participating firms, are given as a percentage of sales. (Rey 2008, 2-7)

According to the sample of 123 firms that provided the figures, total logistics costs in Colombia were equivalent to 12.48 per cent of sales in 2008 (median $9.41 \%$ ). The figures for the different industries are depicted in Figure 28. (Rey 2008, 93-94)

\subsubsection{The Japan Institute of Logistics Systems database}

The Japan Institute of Logistics Systems (JIL) has maintained a nationwide database tracing developments in transport and logistics since 1991. Logistics costs are divided among three components: transport, storage and other costs. In the latest available year (2007) total logistics costs reached 45,992 billion Yen (approximately EUR 279 bn.). Figure 29 depicts the development of Japanese logistics costs as a percentage of GDP. (JIL Database; JIL Database - Logistics Cost Data)

\subsubsection{Studies of the Federation of Norwegian Transport Users (TF)}

The Federation of Norwegian Transport Users (TF) has published two questionnairebased studies on the industry's logistics costs and resource utilization. The respective numbers of respondents were 127 (1999) and 430 (2003) (Natedal 2003, 2-5).

Logistics costs are broken down into five components, the biggest of which is transportation ( $67 \%$ of all costs). The other components are warehousing, inventory holding, administration and other costs. (Natedal 2003, 19) 


\subsubsection{Summary}

Figure 5 and Table 2 summarise the questionnaire-based surveys reviewed above. The numerical values in Figure 5 stand for total logistics costs as a percentage of sales or turnover in the different countries. The year quoted indicates the year of the data collection rather than the year of publication.

Figure 5. The Levels of Total Logistics Costs in Single-country Surveys as a percentage of GDP

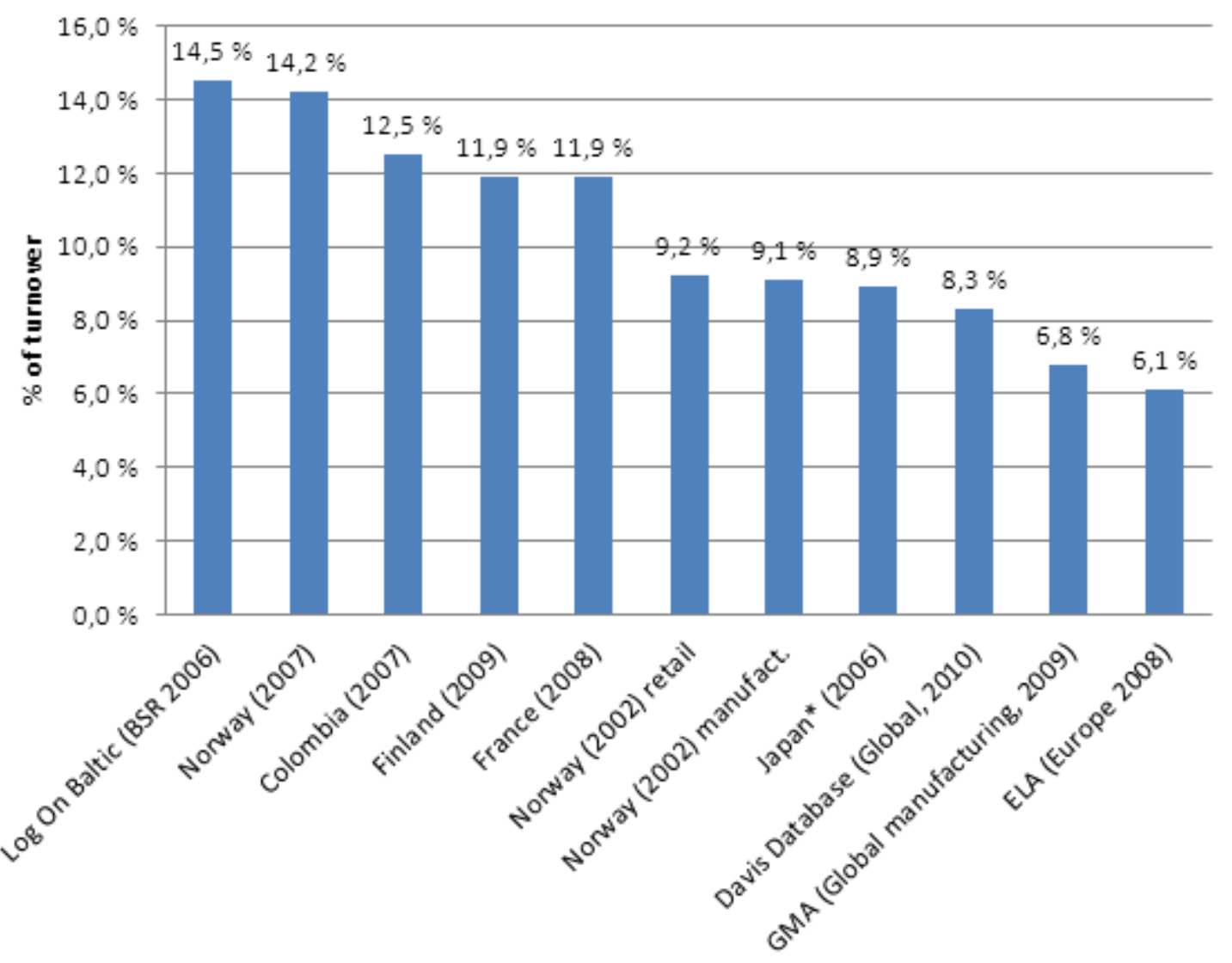

* as a percentage of sales

As the figure indicates, questionnaire-based surveys are very common in Western countries, and single-country studies seem to report higher levels of logistics costs than multi-country studies. 
Table 2. A Summary of Questionnaire-based Surveys

\begin{tabular}{|c|c|c|c|c|c|c|c|c|c|c|c|c|c|c|}
\hline $\begin{array}{r}\text { Study } \\
\text { (year of publication) }\end{array}$ & 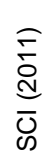 & 步 & 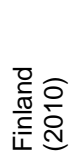 & $\frac{0}{0_{0}^{\circ}}$ & $\begin{array}{l}\widehat{O} \\
\stackrel{\circ}{\mathfrak{d}} \\
: \overline{0} \\
:\end{array}$ & 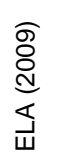 & 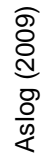 & 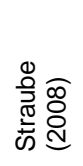 & 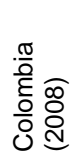 & 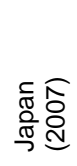 & 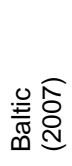 & 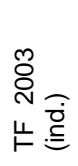 & 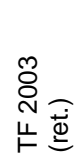 & 々 \\
\hline $\begin{array}{l}\text { Scope (Multi/Single } \\
\text { country) }\end{array}$ & $S$ & $\mathrm{M}$ & $S$ & M & $S$ & M & $S$ & M & $S$ & $S$ & M & $S$ & $\mathrm{~s}$ & O \\
\hline \multicolumn{15}{|c|}{ Cost components } \\
\hline Transportation & & $\sqrt{ }$ & $\checkmark$ & $\checkmark$ & 9 & 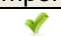 & $\checkmark$ & $\checkmark$ & & $\checkmark$ & $\checkmark$ & $\checkmark$ & $\checkmark$ & 12 \\
\hline Warehousing & & $\checkmark$ & $\checkmark$ & & $\checkmark$ & $\checkmark$ & $\checkmark$ & $\checkmark$ & & $\checkmark$ & $\checkmark$ & $\checkmark$ & $\checkmark$ & 12 \\
\hline Administration & & $\checkmark$ & $\checkmark$ & & $\sqrt{ }$ & $\checkmark$ & $\checkmark$ & $\checkmark$ & & & $\checkmark$ & $\checkmark$ & $\checkmark$ & 11 \\
\hline Inventory carrying & & $\checkmark$ & $\checkmark$ & & & $\checkmark$ & & $\checkmark$ & & & $\checkmark$ & $\checkmark$ & & 7 \\
\hline Other logistics & & & $\checkmark$ & $\checkmark$ & & & & & & $\checkmark$ & $\checkmark$ & $\checkmark$ & & 5 \\
\hline Transport pack. & & & $\checkmark$ & & $\checkmark$ & & & & & & & & & 3 \\
\hline Insurance & & & & & $\checkmark$ & & & & & & & & & 2 \\
\hline Obsolescence & & & & & $\checkmark$ & & & & & & & & & 2 \\
\hline $\begin{array}{l}\text { Customer serv./order } \\
\text { entry }\end{array}$ & & $\checkmark$ & & & & & & $\checkmark$ & & & & & & 2 \\
\hline Cost of capital & & & & & $\checkmark$ & & & & & & & & & 1 \\
\hline Distribution centres & & & & $\checkmark$ & & & & & & & & & & 1 \\
\hline Management/overhead & & & & $\checkmark$ & & & & & & & & & & 1 \\
\hline \multicolumn{15}{|c|}{ Industry classification } \\
\hline Manufacturing & & & $\checkmark$ & $\checkmark$ & $\checkmark$ & & & 7 & $\checkmark$ & & 15.3 & $\checkmark$ & $\checkmark$ & \\
\hline Trade & & & $\sqrt{7}$ & & $\checkmark$ & & & 15.9 & $\checkmark$ & & 13.7 & & & \\
\hline Total costs & $\checkmark$ & $\checkmark$ & $\checkmark$ & & $\checkmark$ & $\checkmark$ & $\checkmark$ & & $\checkmark$ & & 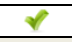 & & & \\
\hline \multicolumn{15}{|c|}{ Time series } \\
\hline-1990 & & $\checkmark$ & $\checkmark$ & & & & & & & & & & & \\
\hline 1991-1995 & & $\checkmark$ & $\checkmark$ & & & & & & & $\sqrt{ }$ & & & & \\
\hline $1996-2000$ & & $\checkmark$ & & & & & & & & $\checkmark$ & & & & \\
\hline $2001-2005$ & 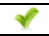 & $\checkmark$ & $\checkmark$ & $\sqrt{9}$ & & 9 & & & & $\checkmark$ & & $\checkmark$ & $\checkmark$ & \\
\hline 2006 & $\checkmark$ & $\sqrt{7}$ & $\checkmark$ & & & & $\checkmark$ & & & $\checkmark$ & & & & \\
\hline 2007 & $\checkmark$ & 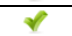 & & & & $\checkmark$ & & & & $\checkmark$ & $\checkmark$ & & & \\
\hline 2008 & 9 & $\checkmark$ & & 9 & & & & $\checkmark$ & 9 & & & & & \\
\hline 2009 & $\checkmark$ & 9 & $\checkmark$ & & & 9 & 9 & & & & & & & \\
\hline 2010 & $\checkmark$ & $\checkmark$ & $\checkmark$ & $\checkmark$ & $\checkmark$ & & & & & & & & & \\
\hline 2011 & $\checkmark$ & $\checkmark$ & & & & & & & & & & & & \\
\hline \multicolumn{15}{|c|}{ Scale of measurement and logistics cost in the most recent study } \\
\hline$\%$ of sales/turnover & & 8.3 & 11.9 & 6.75 & 14.2 & 6.1 & 11.9 & & 12.5 & & 14.5 & 9.1 & 9.2 & \\
\hline$\%$ of GDP & & & 8.7 & & 14.7 & & & $\checkmark$ & & 8.9 & & & & \\
\hline $\begin{array}{l}\text { Absolute costs (bn. } \\
\text { euro) }\end{array}$ & & & 25.4 & & 32 & & & & & 279 & & 28.8 & & \\
\hline
\end{tabular}

Table 2 shows some essential aspects of the reviewed questionnaire-based studies, such as the coverage (multi country / single country; M/S), the cost components and the year of publication. The table also indicates the level of logistics costs, the measurement scale, recent trends, future expectations and study area.

\subsection{Case and Other Studies}

This subchapter lists studies that apply a case-study approach and those in which the method is not disclosed. Case studies are primarily used in countries in which insufficient statistical data is available or the environment is otherwise unfavourable in terms of collecting data, which is often the case in low-income countries. These studies vary a great deal in relevance and comparability, therefore only some of them are discussed below. 
The World Bank publishes numerous case studies. Most World Bank reports on logistics group costs in three categories (see e.g., World Bank report 1/2006, 19; World Bank report 2/2007, 6; Gonzalez, Guasch, \& Serebrisky, 2008, 8):

1) Transaction costs (related to transport and trade, the processing of permits, customs and standards);

2) Financial costs (inventory, storage, security) and;

3) Non-financial costs (insurance).

Arvis, Raballand and Marteau (2007) propose a different grouping (transportation costs, other logistics costs and delay-hedging costs), mainly because their study examines logistics costs in landlocked countries (Arvis, Raballand \& Marteau 2007, 1516). The results of various World Bank studies are presented in Figure 30, Figure 31, and Table 7.

Other organizations that have conducted case studies on logistics costs include the following:

The Logistics Report 2011 UK was published by the Freight Transport Association (FTA) United Kingdom. The report employs data acquired from several different sources (e.g., the FTA Logistics Industry Survey 2010/11) and allocates costs to four key areas: wages, vehicle operation, warehousing and haulage. (The Logistics Report 2011 UK, 6-7)

\begin{abstract}
A case study conducted by the Ministry of Transport in New Zealand, according to which national logistics costs represent around 8.4 per cent of the total turnover in firms (weighted average). Total costs are categorised as direct transportation costs (international/domestic movements, mode interchanges), indirect transportation costs (port charges, customs/bio-security, insurance) and other costs (packaging, warehousing, inventory holding, stock wastage, administration and information systems). (Ministry of Transport in New Zealand 2010, 2-21)
\end{abstract}

Cambodian Institute for Cooperation and Peace surveyed logistics costs and time spent in 20 exporting firms. The findings indicate that costs are still very high. (Sotharith \& Vannarith 2010, 84)

SMEs in Mexico: Campos-Garcia et al. adopted a local SME perspective on logistics costs in their case study of 99 SMEs located in Queretaro, Mexico. According to the analysis, the mean percentage of total costs in the sample was 21.94. (Campos-Garcia, Garcia-Vidales \& Gonzalez-Gomez 2010, 1245-1250)

The Barometer of logistics costs in Catalonia, Spain, continuously measures developments in terms of the weighted average costs of 1) staff (including personnel, social costs, operations, administration and temporary employees), 2) storage (costs associated with running the warehouse), 3) transport (including outsourced activities) and 4) other costs (all logistics-related costs not otherwise mentioned). (Catalonia Logistics Barometer methodology, 1) 
Voice of the Customer study in 2009, conducted by Frost \& Sullivan, explores the state of logistics service providers in four ASEAN countries - Thailand, Malaysia, Indonesia and Singapore. According to the results, the cost of logistics as a percentage of total sales is lowest in Singapore (approximately $8 \%$ ) and highest in Indonesia (19\%). (Frost \& Sullivan 2009)

Logistics costs in the ASEAN region (Brunei, Cambodia, Indonesia, Lao PDR, Malaysia, Myanmar, the Philippines, Singapore, Thailand and Vietnam: Banomyong, Cook \& Kent (2008, 360-362). The study is based on seven questionnaires related to logistics activities in customs, ports and maritime transport, rail-, inland waterway- and air transport as well as logistics services.

The Pakistan Logistics Cost Study was conducted in 2006, and reports a decrease in average costs from 11.01 (1996) to 6.11 per cent of turnover. (Pakistan Logistics Cost Study 2006, 2)

Ireland's National Institute for Transport and Logistics conducted a small survey on logistics costs among Irish firms. From the sample of 20 company representatives, 58 per cent reported that they did not know their total supplychain costs. However, those who had made the calculations suggested an average 34 per cent of turnover (warehousing costs were, on average, 5.1\%). (Smith \& Huber 2005, 15-19)

Logistics costs in the Wielkopolska region of Poland in 2003 was the subject of a study conducted by Wajszczuk \& Wielicki (2004) among four local enterprises consisting of three-to-five-unit farms. The authors delineate three main cost categories: the physical flow of material, inventory costs and the cost of information processing, all quoted as absolute costs per hectare. (Wajszczuk \& Wielicki 2004, 196-200)

Ghana Ministry of Health estimated logistics costs in their system for 1999. The data was based on interviews, as well as inventory records and accounting reports. The costs were divided among three functions: procurement $(7 \%)$, storage $(73 \%)$ and transportation (20\%). (Huff-Rouselle, Raja 2002, 5-6)

Indian Logistics Industry Insight (2007) reports Indian logistics costs in 20052006 as RMB 4,226 billion (approximately EUR 443 bn.), which represents 13 per cent of its GDP. Six cost components are identified in the study: transportation (35\% of total costs), inventories (25\%), losses (14\%), packaging $(11 \%)$, handling and warehousing $(9 \%)$ and customers' shopping (6\%). (Indian Logistics Industry Insight - Aviation 2007, 14)

Logistics indicators were in focus in research conducted by Hausman, Lee, and Subramanian (2005), who used global indicators from 80 economies to create a three-stage estimation process in order to develop a single logistics index. The model includes four cost components: transportation (shipping), trade-related costs (processing, customs clearance, and port operations and the like), in-transit inventory-holding costs, and safety-stock inventory-holding costs. (Hausman et. al. $2005,1-4 ; 19-21$ ) 


\subsection{A summary of macro logistics-costs surveys}

Figure 6 positions all the studies discussed in Chapter 3 along three dimensions: theme, methodology and coverage. The numbered order of the studies follows the order of publication in the respective methodological group. The figure summarises all the cost components identified in previous research.

As Figure 6 shows, logistics costs are usually studied in single countries (92.5\%). Moreover, more than half $(60 \%)$ of them are multi-theme studies. Around 30 per cent of the studies employed the survey method, 23 per cent are statistics-based, and 47 per cent adopt the case-study or some other approach. However, it should be noted that survey and statistics-based methods tend to be more reliable if they are applicable. Surveys usually address multiple themes, which is logical given that several different themes can be covered in the same survey with very little additional work. In conclusion, it could be said that the most popular macro-level type of logistics survey is the multitheme single-country study. Table 3 below lists the reviewed surveys and statistics-based studies according to the year of publication in order to give some idea of their frequency. Case and other studies are excluded at this point because they are conducted at one point in time.

Table 3. Timelines of questionnaire-based surveys and statistics-based studies (excluding case and other studies)

\begin{tabular}{|c|c|c|c|c|c|c|c|c|c|c|c|c|c|c|c|c|c|c|}
\hline \multirow{15}{*}{ 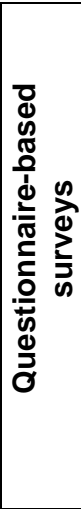 } & Study & 95 & 96 & 97 & 98 & 99 & 00 & 01 & 02 & 03 & 04 & 05 & 06 & 07 & 08 & 09 & 10 & 11 \\
\hline & Davis* & $\checkmark$ & $\checkmark$ & $\checkmark$ & $\checkmark$ & $\checkmark$ & $\checkmark$ & 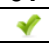 & $\checkmark$ & $\sqrt{9}$ & $\checkmark$ & $\checkmark$ & 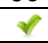 & 9 & 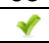 & $\checkmark$ & $\checkmark$ & 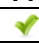 \\
\hline & Finland $^{*}$ & & & 9 & & & & 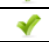 & & & & & 9 & & & $\checkmark$ & $\checkmark$ & \\
\hline & $\mathrm{SCl}$ & & & & & & & & & $\sqrt{9}$ & $\checkmark$ & $\checkmark$ & 9 & 9 & $\checkmark$ & $\checkmark$ & $\checkmark$ & 9 \\
\hline & GMA & & & & & & & & & & & 9 & & & 9 & & $\checkmark$ & \\
\hline & TÖl & & & & & & & & & & & & & & & & $\checkmark$ & \\
\hline & ELA & & & & & & & & & & $\vartheta$ & & & 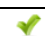 & & $\checkmark$ & & \\
\hline & Norway & & & & & & & & & 9 & & 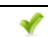 & & 9 & & $\checkmark$ & & \\
\hline & Aslog & & & & & & & & & & & & 9 & & & 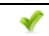 & & \\
\hline & Straube & & & & & & & & & & & & & & $\vartheta$ & & & \\
\hline & Colombia & & & & & & & & & & & & & & 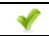 & & & \\
\hline & PwC & & & & & & & & & & & & & & 9 & & & \\
\hline & Japan & $\checkmark$ & $\checkmark$ & $\vartheta$ & $\checkmark$ & $\checkmark$ & 9 & 9 & $\vartheta$ & 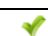 & $\checkmark$ & $\checkmark$ & $\checkmark$ & $\vartheta$ & & & & \\
\hline & $\mathrm{TF}$ & & & & & & & & & 9 & & & & & & & & \\
\hline & SUM & 2 & 2 & 3 & 2 & 2 & 2 & 3 & 2 & 5 & 4 & 5 & 5 & 5 & 6 & 6 & 5 & 2 \\
\hline \multirow{13}{*}{ 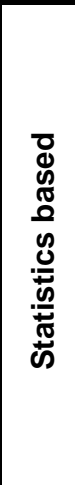 } & CSCMP* $^{*}$ & $\checkmark$ & $\checkmark$ & $\checkmark$ & 9 & $\checkmark$ & $\checkmark$ & $\checkmark$ & $\checkmark$ & $\checkmark$ & $\checkmark$ & $\checkmark$ & 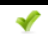 & $\checkmark$ & 9 & $\checkmark$ & $\checkmark$ & 9 \\
\hline & S-Africa & & & & & & & & & & 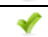 & 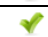 & 9 & $\checkmark$ & 9 & $\vartheta$ & 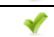 & $\vartheta$ \\
\hline & $\begin{array}{l}\text { Switzerlan } \\
\text { d }\end{array}$ & & & & & & & & & & & & & & & $\checkmark$ & & $\checkmark$ \\
\hline & CFLP & & & & & & & & & & & & $\checkmark$ & $\sqrt{ }$ & $\checkmark$ & $\checkmark$ & $\checkmark$ & $\checkmark$ \\
\hline & Nederland & & & & & & & & & & & & & 9 & & $\checkmark$ & & \\
\hline & Thailand & & & & & & & & & & & & & 9 & 9 & 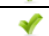 & & \\
\hline & Canada & & & & & & & & & & & & 9 & & 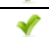 & & & \\
\hline & Korea & & & & & & & & & & & & & & & & 9 & \\
\hline & KPMG & & & & & & & & & & & & & & 9 & & & \\
\hline & Klaus & & & & & & & & & & & & & 9 & & & & $\checkmark$ \\
\hline & Morocco & & & & & & & & & & & & $\checkmark$ & & & & & \\
\hline & Vinnova & & & & & & & & & & & $\checkmark$ & & & & & & \\
\hline & SUM & 1 & 1 & 1 & 1 & 1 & 1 & 1 & 1 & 1 & 2 & 3 & 5 & 6 & 6 & 6 & 4 & 5 \\
\hline \multicolumn{2}{|c|}{ TOTAL SUM } & $m$ & $m$ & $\theta$ & $m$ & $m$ & $m$ & $\theta$ & $m$ & 0 & $\bullet$ & $\infty$ & 으 & $\mp$ & ฯ & $\stackrel{N}{\sim}$ & 0 & $\Lambda$ \\
\hline
\end{tabular}

* before 1995

Karri Rantasila \& Lauri Ojala - Discussion Paper 2012-4 - (c) OECD/ITF 2012 
Figure 6. Positioning Logistics Studies in Accordance with the Methodology, Coverage and Theme

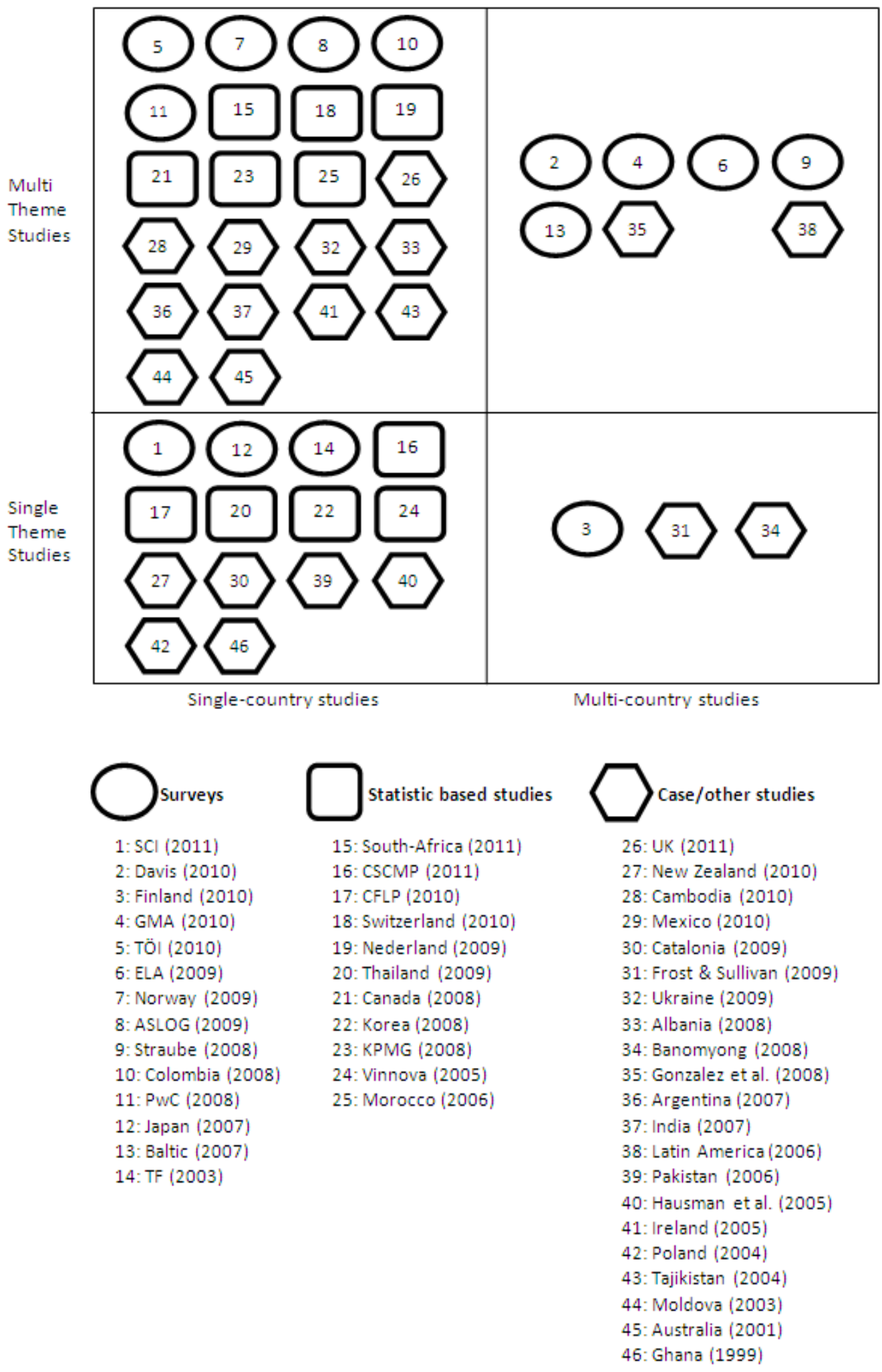


The table lists studies published after 1995, even though some (i.e. Davis Database, Finland State of Logistics survey, and the CSCMP State of Logistics study) predate 1995. The number of studies has increased significantly since that year, as illustrated in Figure 7.

The upward trend reflects the growing interest in macro logistics costs. According to the trend lines by the methodology applied, the number of statistics-based studies has increased more than that of case studies and surveys. Furthermore, the total number of published studies rose sharply between 2003 and 2008.

Figure 7. Numbers of Studies on Logistics Costs Published since 1990

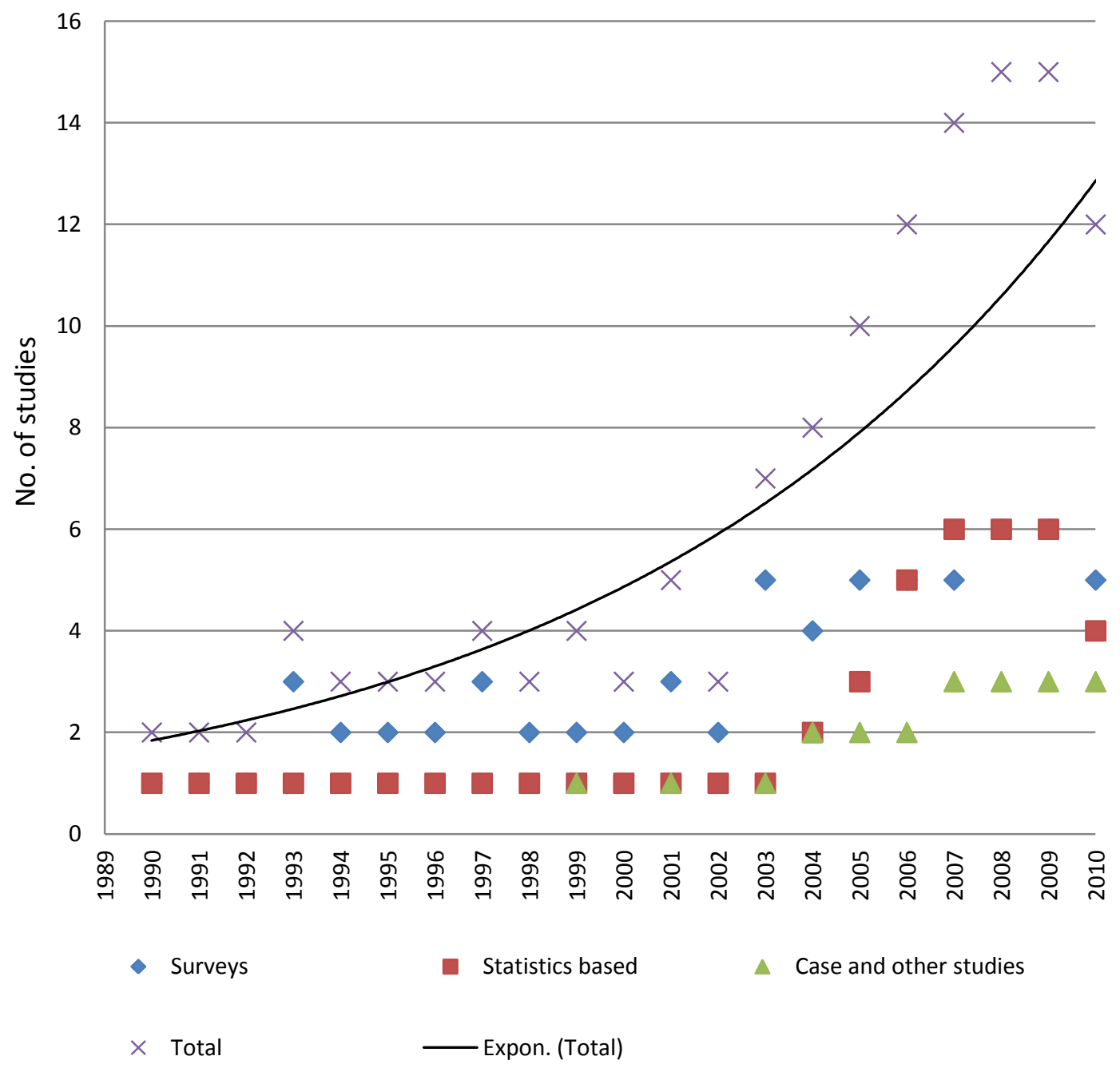


Finally, Figure 8 shows the geographical distribution of the reviewed studies, which are placed on the LPI world map in order to pinpoint the countries in which they were conducted.

Figure 8. Published Studies in World Map and LPI Performance

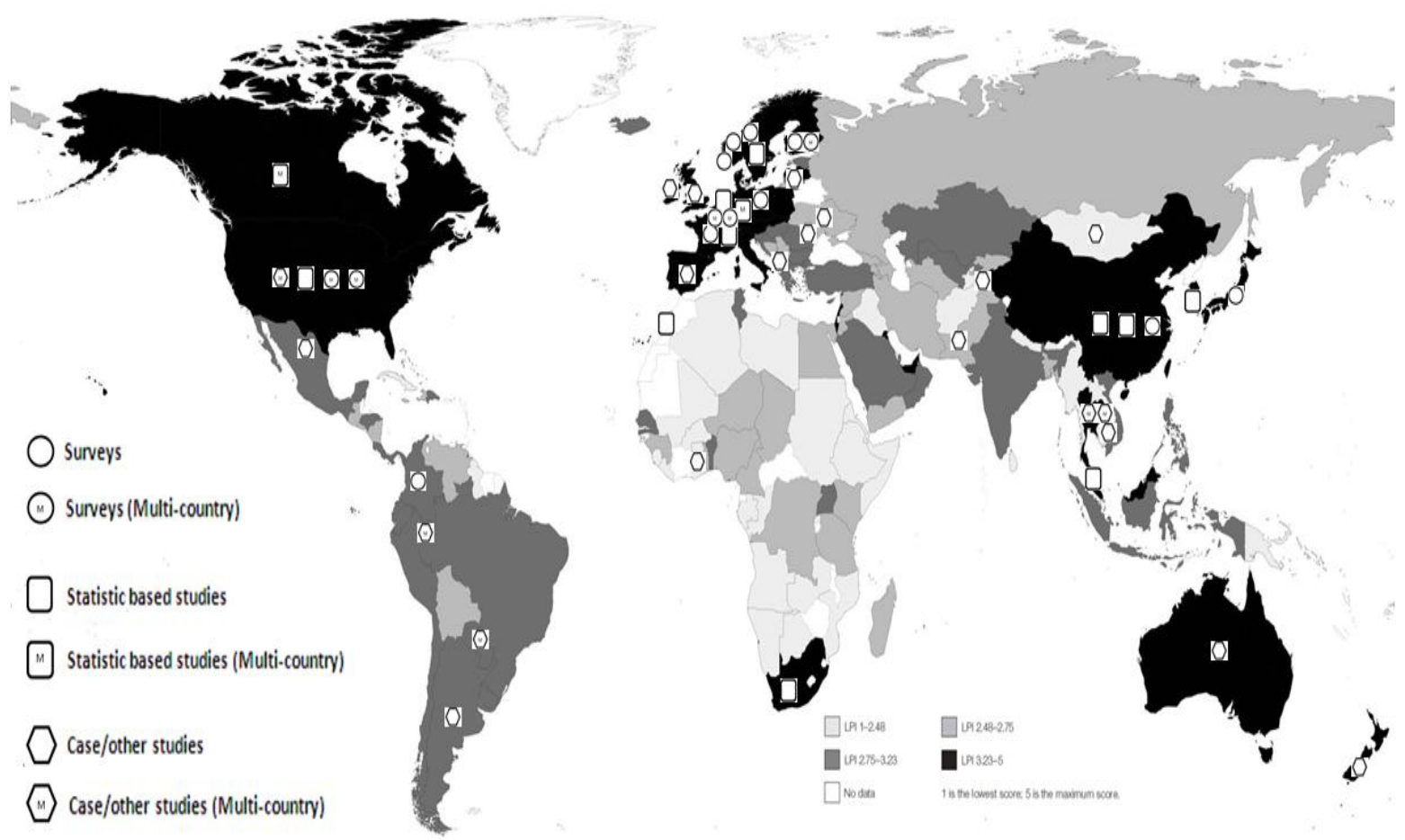

Source: map: Arvis, Mustra, Panzer, Ojala \& Naula 2007)

There is a clear relationship between the LPI ranking and the areas in which the studies are undertaken. This may indicate that countries with a high interest in logistics costs also achieve high LPI scores. Naturally, however, the LPI ranking tends to be higher in developed countries, which can devote more resources to conducting studies. This also reflects, on some level, the importance of the research in terms of maintaining logistics efficiency.

One can thus conclude that, in general, research on logistics costs is strongly concentrated in developed countries, at least as far as surveys and statistics-based studies are concerned. Most of the case studies and other investigations conducted in developing countries are funded and initiated by organizations such as The World Bank Group. Europe and North America are powerhouses of research, and the Nordic countries in particular have excelled in their efforts. One difference between European and NorthAmerican studies is that surveys are favoured in Europe, whereas North-American studies tend to be statistics-based. 


\section{POLICY IMPLICATIONS}

Understanding logistics performance and costs at the country level is important in order to better evaluate and target policy efforts not only in the transport sector, but across sectors. Lower costs for logistics reduce the cost of delivering products nationally as well as internationally, thereby encouraging sales, increasing trade, opening new markets and generally encouraging business.

Performance evaluation also helps to improve the efficiency of supply chains and the functioning of related infrastructures, services, procedures and regulation. A sound and comprehensive set of national-level performance indicators is critical for high-level policy dialogue, preparation and implementation. In order to do prepare facts-based policies, policymakers need a solid understanding, among other things, of the following:

i) The level of logistics costs in absolute terms and relative to other costs;

ii) The main drivers of logistics costs;

iii) How costs and deficiencies in performance affect certain sectors in the economy.

While this Discussion Paper cannot provide answers to all of those questions, it presents and categorizes available national-level assessments of logistics costs, including the methods applied and comprising:

(1) Survey instruments based on primary data, and their results;

(2) Models of logistics costs based on national accounts and other relevant data.

Existing cross-country comparisons meet this demand only in part. Separate national surveys and studies aimed at filling this knowledge gap have been carried out only in some High Income Countries. Only sporadic efforts in Low Income Countries exist, which have mainly been part of country assistance work by the World Bank. Thus far these activities have proceeded in isolation.

Furthermore, the applied methods and/or data tend to differ significantly from one study to another, making it difficult to compare the findings. The main caveats could be summarised as follows:

- Logistics costs are neither an accounting nor a statistical unit, which means that the term is vague and often ill-defined or understood;

- In self-reporting surveys, the data are, by definition, subjective, and aggregation may lead to "double counting" or omissions across sectors or supply chains;

- Self-reported data in national surveys typically include firms' international supply chains beyond national borders; hence results are not limited to just one country;

- Statistics-based studies rely on data that covers only national activities; 
- Irrespective of method, the increasingly complex and international supply chains of firms and related service provision are becoming more difficult to study.

Despite these issues related to the choice of methodology and comparability of results, work is going on to understand these issues better. A serious global effort is already underway to bring the dedicated research institutions and other stakeholders together on this matter. This work has been sponsored by The World Bank with a view to establishing a network of researchers and research institutions dealing with national-level logistics cost and performance measurement.

This network-in-the-making, called the Logistics Performance International Observatory (LPIO), has already organised meetings since 2010 in Washington, Germany and Thailand, in which researchers and experts from (in alphabetical order) Brazil, Canada, China, Finland, Germany, India, Indonesia, Japan, Malaysia, Norway, Philippines, Singapore, South Africa, Switzerland, Thailand, USA and Vietnam have taken part. A follow-up meeting is planned for end-June 2012 in Washington, with a smaller gathering in early June 2012 in Finland.

The main message of this Discussion Paper is that information on national level logistics performance and costs is becoming increasingly important in national and also regional policy-making in view of competitiveness, for example. Countries, where a time series of data is already available from previous studies have an advantage.

In countries, where such studies have been conducted, the Ministries of Transport (or equivalent) have often been either initiating or commissioning this type of work.

Countries, which have not yet started to contemplate on initiating this type of work, are advised to do so in the near future. Several "tools" for the job exist already, and they are getting shaper and better all the time. And they are affordable, too. 


\section{BIBLIOGRAPHY}

Arvis, J-F. - Raballand, G. - Marteau. J-F. (2007) The Cost of Being Landlocked: Logistics Costs and Supply Chain Reliability, World Bank Policy Research Working Paper 4258. <http://www wds. worldbank.org/external/default/main?pagePK=64193027\&piPK=64187937\&theSitePK=523679 \&menuPK $=64187510$ \&searchMenuPK $=64187283$ \&theSitePK $=523679$ \&entityID $=000016406 \_20070$ 615150019\&searchMenuPK=64187283\&theSitePK=523679>

Arvis, J-F. - Mustra, A. - Panzer, J. - Ojala, L. - Naula, T. (2007). Connecting to Compete 2007: Trade Logistics in the Global Economy. The Logistics Performance Index and Its Indicators; The World Bank; <www.worldbank.org/lpi>

Arvis, J-F - Mustra, M. A. - Ojala, L. - Shepherd, B. - Saslavsky, D. (2010) Connecting to Compete 2010: Trade Logistics in the Global Economy. The Logistics Performance Index and Its Indicators; The World Bank <http://siteresources.worldbank.org/INTTLF/Resources/LPI2010_for_web.pdf>

ASLOG - L'etat de l'art de la Locistique Française. <http://www.aslog.org/fr/ACTU_historique.php?niv2=31\&id_actu=315>

Ayers, J. (2006) Handbook of Supply Chain Management $2^{\text {nd }}$ Edition. Boca Raton, FL, USA

Banomyong, R. - Cook, P. - Kent, P. (2008) Formulating Regional Logistics Development Policy: The Case of ASEAN. International Journal of Logistics: Research and Applications. Vol. 11, No. 5, pp. 359-379

Banomyong, R. - Supatn, N. (2011) Developing a supply chain performance tool for SMEs in Thailand, Supply Chain Management: An International Journal, Vol. 16, No.1, pp: 20-31

Barbero J A (2010) Freight Logistics in Latin America and the Caribbean: An Agenda to Improve Performance, Inter-American Development Bank Infrastructure and Environment Department, TECHNICAL NOTES No. IDB-TN-103

Bidgoli, H. (2010) The Handbook of Technology Management: Supply Chain Management, Marketing and Advertising, and Global Management, $2^{\text {nd }}$ edition, Hoboken, New Jersey, US

Bowersox, D. - Rodrigues, A. - Calantone, R. (2005) Estimation of Global and National Logistics Expenditures: 2002 Data Update. Journal of Business Logistics, Vol. 26, No.2, pp.1-16

Bowersox, D. - Calantone, R. - Rodrigues, A. (2003) Estimation of Global Logistics Expenditure Using Neural Networks. Journal of Business Logistics, Vol. 24, No. 2, pp. 21-36

Brewer, A.M. - Button, K.J. - Hensher, D.A. (2001) Handbook of logistics and supply-chain management, Oxford, UK

Campos-Garcia, R.M. - Garcia-Vidales, M.A. - Gonzalez-Gomez, O. (2010) Relationship between cost and logistics practices in small and medium enterprises: A case study of Queretaro, Mexico, African Journal of Business Management, Vol.5, Iss.4, pp. 1245-1252

Catalonia Logistics Barometer methodology, available at <http://www.bcncl.es/barometro/Metodologia\%20Barometre\%20costos.pdf>

CFLP (2007), China Federation of Logistics and Purchasing 2007, <http://www.sdpc.gov.cn/zjgx/t20070315_121530.htm>

CFLP (2008), China Federation of Logistics and Purchasing 2008, <http://yxj.ndrc.gov.cn/xdwl/t20080327_200477.htm>

CFLP (2009), China Federation of Logistics and Purchasing 2009, <http://www.ndrc.gov.cn/jjyx/xdwl/t20090306_264999.htm> 
CFLP (2010), China Federation of Logistics and Purchasing 2010, <http://yxj.ndrc.gov.cn/xdwl/t20100310_334070.htm>

CFLP (2011), China Federation of Logistics and Purchasing 2011, <http://www.ndrc.gov.cn/zjgx/t20110301_397842.htm>

Choi, C-Y - Lee, J-Y (2009) Strategic Issues for Korean distribution companies' penetration of the Chinese market. Journal of International Logistics and Trade, Vol. 7, No.2, pp. 83-98

Coyle, J- Langley, J. - Bardi, E. - Gibson, B. - Novack, R. (2009) Supply chain management: a logistics perspective, $8^{\text {th }}$ edition, Mason, $\mathrm{OH}$, US

Coyle, J. - Bardi, C. - Langley, J. (1988) The Management of Business Logistics, $4^{\text {th }}$ Edition. St. Paul, MN, USA

Creazza, A. - Dallari, F. - Melacini, M. (2010) Evaluating logistics network configurations for a global supply chain Supply Chain Management: An International Journal, Vol. 15, No. 2, pp: 154164

CSCMP $19^{\text {th }}$ Annual State of Logistics Report 2008.

<http://cscmp.org/memberonly/state.asp>

CSCMP's 20 ${ }^{\text {th }}$ Annual State of Logistics Report 2009.

<http://cscmp.org/memberonly/state.asp>

Davis Database Presentation 2008.

<http://www.establishinc.com/sendmail.asp?d=CSCMP_2008\&l=../pdfs/2008_CSCMP_Presentation .pdf $>$

Davis Database Presentation 2009.

<http://www.establishinc.com/sendmail.asp?d=CSCMP_2009\&l=../pdfs/2009_Logistics_Cost_and_ Service_Presentation.pdf>

Davis Database Presentation 2010 (2010), available at <http://www.establishinc.com/pdfs/2010_Logistics_Cost_and_Service_Presentation.pdf>

Davis Logistics Cost and Service Database.

<http://www.establishinc.com/davisdatabase_info.asp>

De Logistieke Kracht van Nederland 2009.

<http://www.ndl.nl/files_content/publicaties/Log_kracht_NL-aug2009.pdf>

Dianwei, Q (2006), The Research on Logistics Cost Accounting and Management in China, Proceedings of 2006 International Conference on Management of Logistics and Supply Chain: September 20-22, 2006, Sydney, Australia

Dimitrov, P (1991) National Logistics Systems, Publications of Institute for Applied Systems Analysis, CP-91-06, Laxemburg, Austria

ELA homepage, About us. < http://www.elalog.org/>

Elger, T. - Lundquist, K-J, Olander, L-O (2008) Svensk Makrologistik, VINNOVA Rapporter 2008:13 < http://www.vinnova.se/upload/EPiStorePDF/vr-08-13.pdf >

European Central Bank, currency data, available at:

<http://www.ecb.europa.eu/stats/eurofxref/eurofxref-hist.xml>

Factsheet zur Logistikmarktstudie: Volumen Logistikmarkt Schweiz, (2011)

<http://www.logistik.unisg.ch/org/logm/web.nsf/SysWebRessources/Factsheet+2+Logistikmarktst udie/\$FILE/LO_2011_02_LMS.pdf>

Farahani, R.Z. - Asgari, N. - Davarzani, H. (2009) Supply Chain and Logistics in National, International and Governmental Environment - Concepts and Models. Physiga-Verlag, Berlin, Germany 
Finnish Governmental Programme 2007.

<http://www.vn.fi/hallitus/hallitusohjelma/pdf/en.pdf>

Frost \& Sullivan (2009) ASEAN Logistics End Users - Trends and Preferences press release 23.12.2009, available at

<http://www.frost.com/prod/servlet/market-insight-top.pag?docid=188456835>

GMA 2010 Logistics Benchmark Report (2010), available at <http://www.gmaonline.org/downloads/research-andreports/GMA_2010_Logistics_Benchmark_Report.pdf>

GMA Logistics Survey 2008.

<http://www.gmabrands.com/publications/GMALogisticsStudy2008.pdf>

Gonzalez - Guasch - Serebrisky (2008) Improving Logistics Costs for Transportation and Trade Facilitation (Policy Research Working Paper 4558). < http://www-

wds.worldbank.org/external/default/main?pagePK=64193027\&piPK=64187937\&theSitePK=523679 \&menuPK $=64187510 \&$ searchMenuPK $=64187283 \&$ theSitePK $=523679$ \&entityID $=000158349 \_20080$ $313132618 \&$ searchMenuPK $=64187283 \&$ theSitePK $=523679>$

Guasch J.L - Kogan J (2006) Inventories and Logistic Costs in Developing Countries: Levels and Determinants-A Red Flag for Competitiveness and Growth. Policy Research Working Paper 2552. Washington DC: World Bank

Guerrero P - Lucenti K - Galarza S (2010) Trade Logistics and Regional Integration in Latin America and the Caribbean, ADBI Working Paper Series No. 233

Hansen, W. - Hovi, I.B. (2010), Logistics costs in Norway, survey results, calculations and international comparison, European Transport Conference 2010, Glasgow, Scotland

Hansen, W. - Hovi, I.B. (2008) En gjennomgang av ulike studier som forsöker å kvantifisere logistikkostnadene. TÖI rapport 969/2008, Oslo, Norway Britain.

Harrison, A. - van Hoek, E. (2002) Logistics Management and Strategy. Ashford, Great

Hausman, W. - Lee, H. - Subramanian, U. (2005) Global Logistics Indicators, Supply Chain Metrics and Bilateral Trade Patterns (World Bank Policy Research Working Paper 3773). < http://www-

wds.worldbank.org/external/default/WDSContentServer/WDSP/IB/2005/11/17/000016406_200511 17161830/Rendered/PDF/wps3773.pdf>

Havenga, J. (2007) The Development and Application of a Freight Transport Flow Model for South Africa, PhD dissertation, University of Stellenbosch

Havenga, J. (2010) Logistics costs in South Africa - The case for macroeconomic measurement, South African Journal of Economics, Vol.74, No.4, pp:460-48

Hollweg, C. - Wong. (2009) Measuring Regulatory Restrictions in Logistics Services, ERIA Discussion Paper Series, ERIA-DP-2009-14, available at: <http://www.eria.org/pdf/ERIA-DP-200914.pdf>

Hovi, I.B. - Hansen, W. (2010), Logistics Costs in Norway: Key figures and international comparison TÖI report 1052/2010, Oslo, Norway, available at: <http://www.toi.no/getfile.php/ Publikasjoner/T\%D8I\%20rapporter/2010/1052-2010/1052-2010-nett-ny.pdf >

Huff-Rouselle, M. \& Raja, S. (2002) Ghana: Estimating the Costs of Logistics in the Ministry of Health Supply System, Arlington, Va., U.S.

Indian Logistics Industry Insight - Aviation (2007), Cygnus Business Consulting \& Research, Banjara Hills, India 
Industriens logistikk - en studie av logistikkostnader og ressursbruk i norskindustri. $<$ http://www.tf.no/modules.php?op=modload\&name=PagEd\&file=index\&p_deliver=media\&m_id=8 $>$

Industry Canada - Logistics Cost and Agility Assessment Tool. <http://www.ic.gc.ca/eic/site/dsib-logi.nsf/vwapj/pg00001_eng.pdf/\$file/pg00001_eng.pdf>

International Monetary Fund, World Economic Outlook. <http://www.imf.org/external/pubs/ft/weo/2009/02/weodata/index.aspx>

Jensen, A (2007) Logistikkostnader, konkurrenskraft och infrastruktur. <http://www.vgregion.se/upload/Regionkanslierna/regionutveckling/Kommunikation/2_Svenska\% 20f\%C3 \%B6retags\%20logistikkostnader.pdf>

JIL Database - Logistics Cost Data, available at http://www.logistics.or.jp/jils/soken2/cntHtml/LgCnt19.html and at <http://www.mlit.go.jp/seisakutokatsu/census/census-top.html>

Kivinen, P. - Lukka, A. (2004) Value Added Logistical Support Service: Logistics cost Structure and Performance in the new Concept. Lappeenranta, Finland

Klaus, P. - Kille, C. - Schwemmer, M. (2011) TOP 100 in European Transport and Logistics Services, executive summary, available at:

<http://www.scs.fraunhofer.de/en/Images/Fraunhofer\%20SCS\%20-\%20Top\%20100

\%20Executive\%20Summary_tcm129-97670.pdf>

Klaus, P. - Kille, C. (2007) TOP 100 in European Transport and Logistics Services, $2^{\text {nd }}$ edition. Bobingen, Germany

KOTI (2010) Korean Macroeconomic Logistics Costs in 2008, $<$ http://english.koti.re.kr/board/report/download.asp?code=research_report\&record_idx=1440\&ty pe $=$ normal $>$

KPMG: Logistics in China 2008.

<http://www.kpmg.com.cn/en/virtual_library/Property_Infrastructure/LogisticsChina.pdf>

Krauth, E - Moonen, H. - Popova, V. - Schut, M (2005) Performance Indicators in Logistics Service Provision and Warehouse Management - A Literature Review and Framework, Erasmus University, available at: http://www.cs.vu.nl/ schut/pubs/Krauth/2005a.pdf

La Logistique du Commerce et la Compétitivité du Maroc 2006. <http://www.mtpnet.gov.ma/Morocco\%20trade\%20logistics\%20Final\%20May\%2030 $\% 202006 . P D F>$

Lambert, D. - Grant, D. - Stock, J. - Ellram, L. (2006) Fundamentals of Logistics Management, European Edition. McGraw-Hill, Maidenhead, Berkshire, UK.

Langley, J. (2008) 2008 Third Party Logistics. <http://3plstudy.com/?p=2008-3pl-study>

Logistics in Australia: A Preliminary analysis (2001), Bureau of Transportation Working Paper no. 49, October 2001

Logistics Report 2007 Thailand.

<http://www.nesdb.go.th/LinkClick.aspx?fileticket=D5g5B0ZId1I\%3D\&tabid=58\&mid=418>

Logistics Report 2011 UK (2011), available at <http://www.fta.co.uk/export/sites/fta/_galleries/downloads/logistics_report/logistics_report_2011 .pdf>

Memedovic, O. - Ojala, L. - Rodrigue, J-P - Naula, T. (2008) Fuelling the global value chains: what role for logistics capabilities? International Journal of Technological Learning, Innovation and Development, Volume 1, No. 3, 2008, pp. 353-376 
Ministry of Transport in New Zealand (2010) Understanding Transport Costs and Charges Transport costs in freight logistics available at <http://www.transport.govt.nz/research/Documents/UTCC-Phase-2-Transport-and-freightlogistics-final-report-Nov2010.pdf>

Natedal, Hilde Astrid Rusten (2003) Industriens logistikk - en studie av logistikkostnader og ressursbruk i norskindustri 2003, 2-5, Transportbrukernes fellesorganisasjon, Oslo

Naula, T. - Ojala, L. - Solakivi, T. - Takalolastari, M. - Rantanen, M. - Kalske, M. - Engblom J. - Häkkinen, L. - Essén, T. - Töyli, J. - Stenholm, P. (2006) Logistics Survey 2006, Publications of the Ministry of Transport and Communications 35/2006, Helsinki, Finland

OECD Economics Department.

<http://www.oecd.org/document/46/0,3343,en_2649_34109_33701806_1_1_1_1,00.html>

OECD Statistics 2. <http://stats.oecd.org/glossary/detail.asp?ID=2368>

OECD Statistics 1. <http://stats.oecd.org/glossary/detail.asp?ID=2780>

Ojala, L. - Solakivi, T. - Hälinen, H-M. - Lorentz, H. - Hoffmann, T.M. (2007) State of Logistics in the Baltic Sea Region 2007. LogOn Baltic Master reports 3:2007. Tampere, Finland

Ojala, L. (1992) Modelling Approaches in Port Planning and Analysis. Publications of the Turku School of Economics and Business Administration, Series A-4:1992, Turku, Finland

Ojala, L. (1995) Logistics Management in Finnish Foreign Trade Transport. Publications of the Turku School of Economics and Business Administration, Series A-3:1995, Raisio, Finland

Ojala, L. (2008) Albania Country Economic Memorandum, Trade Logistics input. Mimeo, unpublished report to The World Bank

Pakistan Logistics Cost Study (2006), Final Report, June 2006, available at <http://www.nttfc.org/reports/Logistics_costs_study_Pakistan_report_June_06.pdf>

Pohlen, T. - Klammer, T. - Cokins, G. (2009) The Handbook of Supply Chain Costing, Lombard, Illinois, USA

Rantasila, K. (2010) Measuring national logistics costs: designing a generic model for assessing national logistics costs in global context, Turku School of Economics Master's Thesis, available at: <http://info.tse.fi/julkaisut/Thesis2010/12927.pdf>

Republic of Moldova: Trade Diagnostic Study (2004), the World Bank Report No. 30998-MD. <http://siteresources.worldbank.org/INTMOLDOVA/Resources/trade1.pdf>

Rey, M.F. (2008), Encuesta Nacional Logística: Resultados del Benchmarking Logístico Colombia 2008, available at < http://www.encuestanacionallogistica.com/docs/file/ REPORTE\%20ENL\%20COLOMBIA.pdf>

Rushton, A. - Croucher, P. - Baker, B. (2006) Handbook of Logistics and Distribution Management ( $3^{\text {rd }}$ edition). Kogan Page. Glasgow, UK

Rushton, A. - Oxley, J. - Croucher, P. (2001) The handbook of logistics and distribution management $2^{\text {nd }}$ Edition, London, UK

SCD - Logistics Cost Survey (2006).

<http://www.scdigest.com/assets/reps/SCDigest_Logistics_Cost_Survey_2006.pdf>

Schwab, K. (2011) The Global Competitiveness Report 2010-2011, World Economic Forum, Geneva, Switzerland.

SCI Verkehr Logistikbarometer July 2011 (2011), available at: <http://www.sci.de/fileadmin/user_upload/logistikbarometer/pdf/2011/050-051DVZ11-I006.pdf>

SCI Verkehr Logistikbarometer November 2009. <http://www.sci.de/fileadmin/user_upload/logistikbarometer/pdf/Auswertung_Nov2009.pdf> 
SCI Verkehr website. <http://www.sci.de/en/company.html>

SCM and KPI Analysis - A Canada / United States Manufacturing Perspective 2006. < http://www.ic.gc.ca/eic/site/dsib-logi.nsf/vwapj/pg00016_eng.pdf/\$file/pg00016_eng.pdf>

SCM and KPI Analysis - A Canada / United States Perspective 2006. <http://www.ic.gc.ca/eic/site/dsib-logi.nsf/vwapj/pg00015_eng.pdf/\$file/pg00015_eng.pdf>

SCM and KPI Analysis - A Canada / United States Retail Perspective 2006. <http://www.ic.gc.ca/eic/site/dsib-logi.nsf/vwapj/pg00017_eng.pdf/\$file/pg00017_eng.pdf>

Seuring, S.A. (2008) Assessing the rigor of case study research in supply chain management, Supply Chain Management: An International Journal, Vol. 13 Iss: 2, pp: 128 - 137

Shepherd, B (2011) Logistics Costs and Competitiveness: Measurement and Trade Policy Applications, Transport Support Research series, a joint World Bank/DFID initiative, available at: http://siteresources.worldbank.org/INTTRANSPORT/Resources/336291-1239112757744/59976931294344242332/Logistics_costs.pdf

Smith, A. - Huber, B. (2005), Comparative Challenges: Chain Reactions: an Analysis of Supply Chain Management and Competitive Solutions for the Island of Ireland, National Institute of Transport Logistics, Dublin, Ireland

Solakivi, T. - Ojala, L. - Lorentz, H. - Laari, S - Töyli, J. (2012, forthcoming in May) Finland State of Logistics 2012, Publications of the Ministry of Transport and Communications Helsinki, Finland.

Solakivi, T. - Ojala, L. - Töyli, J. - Hälinen, H-M. - Lorentz, H. - Rantasila, K. - Huolila, K. Laari, S. (2010) Finland State of Logistics 2010, Publications of the Ministry of Transport and Communications 36/2010, Helsinki, Finland.

Solakivi, T. - Ojala, L. - Töyli, J. - Lorentz, H. - Hälinen, H-M. - Rantasila, K. - Naula, T. (2009) Finland State of Logistics 2009, Publications of the Ministry of Transport and Communications 21/2009, Helsinki, Finland

Sotharith, C. - Vannarith, C. (2010) Cambodian Economy, CICP E-BOOK NO.5, available at: < http://www.cicp.org.kh/download/CICP\%20E-Book/cicp\%20e-book\%20no\%205.pdf>

State of Logistics Survey for South Africa 2004, Pretoria, South Africa

State of Logistics Survey for South Africa 2007, Pretoria, South Africa

State of Logistics Survey for South Africa 2008.

<http://www.csir.co.za/pdf/2009/SOL_2008.pdf>

State of Logistics Survey for South Africa 2010 (2011), available at: <http://www.csir.co.za/sol/docs/7th_SoL_2010_March.pdf>

State of Logistics: The Canadian Report 2008. <http://www.ic.gc.ca/eic/site/dsiblogi.nsf/vwapj/pg00026_eng.pdf/\$file/pg00026_eng.pdf>

Straube, F. - Pfohl, H-C. (2008) Trends and Strategies in Logistics: Global Networks in an Era of Change. Bundesvereinigung Logistik e.V., Berlin, Germany

Stölzle, W. - Hofmann, E. - Gebert, K. (2009) Logistikmarktstudie Schweiz 2010, St. Gallen, Switzerland

Supply-Chain-Excellence in der globalen Wirtschaftskrise (2009) ELA \& A.T. Kearney publications. Dusseldorf, Germany

Tajikistan Trade Diagnostic Study (2005), World Bank report Report No. 32603-TJ. <http://siteresources.worldbank.org/INTRANETTRADE/Resources/Pubs/TajikTradeStudy.pdf> 
Thailand Logistics Report 2008 (2009), publications of Office of National Economic and Social Development Board, December 2009, available at:

<http://www.logisticsdigest.com/images/stories/Articles_Jun10/LogisticsCost_2008eng.pdf>

Ukraine: Trade and Transit Facilitation Study (2010), The World Bank Kyiv; at: http://siteresources.worldbank.org/UKRAINEEXTN/Resources/TTF_April2010.pdf

UN ESCAP (2002) Commercial Development of Regional Ports as Logistics Centres, at: http://www.unescap.org/ttdw/Publications/TFS_pubs/pub_2194/pub_2194_fulltext.pdf

Wajszczuk, K. - Wielicki, W. (2004) The Level and Structure of Logistics Costs in Great Area Agricultural Enterprises, Publications of Roczniki Akademii Rolniczej w Poznaiu - CCCLIX, Ekon.3, Poznan, Poland, available at: <http://www.jard.edu.pl/pub/18_3_2004.pdf>

Williamson, O.E. (1981) The Economics of Organization: The Transaction Cost Approach, American Journal of Sociology. Vol. 87, No. 3, pp. 548-577

Williamson, O.E. (2008) Outsourcing: Transaction Cost Economics and Supply Chain Management, Journal of Supply Chain Management. Vol. 44, No. 2, pp. 5-16

Wilson, R. (2011) U.S Annual State of Logistics Report -presentation, presented at World Bank, Washington, DC, June 17, 2011

Visser, E-J. (2007) Logistic innovation in global supply chains: an empirical test of dynamic transaction-cost theory, GeoJournal, Vol. 70, No. 2-3, pp: 213-226

World Bank reports 1 (2006), Argentina - The Challenge of Reducing Logistics Costs. Report No. 36606-AR, <http://www-

wds. worldbank.org/external/default/main?pagePK $=64193027 \&$ piPK $=64187937$ \&theSitePK $=523679$ \&menuPK =64187510\&searchMenuPK=64187283\&theSitePK=523679\&entityID=000020439_20071 $108092451 \&$ searchMenuPK=64187283\&theSitePK $=523679>$

World Bank reports 2 (2007), Latin America: Addressing High Logistics Costs and Poor Infrastructure for Merchandise Transportation and Trade Facilitation. $<$ http://www.copenhagenconsensus.com/Admin/Public/DWSDownload.aspx?File=\%2FFiles\%2FFiler

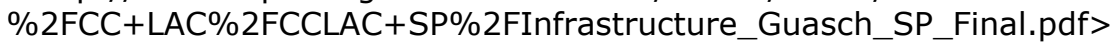

Zeng, A. - Rossetti, C. (2003) Developing a framework for evaluating the logistics costs in global sourcing processes, International Journal of Physical Distribution \& Logistics Management, Vol. 33, No.9, pp. 785-803 


\section{ATTACHMENT}

Figure 9. Logistics Performance Index, Top 20 Performers in 2010

\begin{tabular}{|c|c|c|c|c|c|c|c|c|}
\hline $\begin{array}{l}\text { Int. } \\
\text { LPI } \\
\text { Rank }\end{array}$ & Country & $v$ & $\begin{array}{c}\text { Customs } \\
? ? ?\end{array}$ & $\begin{array}{c}\text { Infrastructure } \\
? ?\end{array}$ & $\begin{array}{c}\text { International } \\
\text { shipments } \\
?\end{array}$ & $\begin{array}{c}\text { Logistics } \\
\text { competence } \\
?\end{array}$ & $\begin{array}{c}\text { Tracking \& } \\
\text { tracing } \\
?\end{array}$ & Timeliness \\
\hline 1 & Germany & 4.11 & 4.00 & 4.34 & 3.66 & 4.14 & 4.18 & 4.48 \\
\hline 2 & Singapore & 4.09 & 4.02 & 4.22 & 3.86 & 4.12 & 4.15 & 4.23 \\
\hline 3 & Sweden & 4.08 & 3.88 & 4.03 & 3.83 & 4.22 & 4.22 & 4.32 \\
\hline 4 & Netherlands & 4.07 & 3.98 & 4.25 & 3.61 & 4.15 & 4.12 & 4.41 \\
\hline 5 & Luxembourg & 3.98 & 4.04 & 4.06 & 3.67 & 3.67 & 3.92 & 4.58 \\
\hline 6 & Switzerland & 3.97 & 3.73 & 4.17 & 3.32 & 4.32 & 4.27 & 4.20 \\
\hline 7 & Japan & 3.97 & 3.79 & 4.19 & 3.55 & 4.00 & 4.13 & 4.26 \\
\hline 8 & $\begin{array}{l}\text { United } \\
\text { Kingdom }\end{array}$ & 3.95 & 3.74 & 3.95 & 3.66 & 3.92 & 4.13 & 4.37 \\
\hline 9 & Belgium & 3.94 & 3.83 & 4.01 & 3.31 & 4.13 & 4.22 & 4.29 \\
\hline 10 & Norway & 3.93 & 3.86 & 4.22 & 3.35 & 3.85 & 4.10 & 4.35 \\
\hline 11 & Ireland & 3.89 & 3.60 & 3.76 & 3.70 & 3.82 & 4.02 & 4.47 \\
\hline 12 & Finland & 3.89 & 3.86 & 4.08 & 3.41 & 3.92 & 4.09 & 4.08 \\
\hline 13 & $\begin{array}{l}\text { Hong Kong, } \\
\text { China }\end{array}$ & 3.88 & 3.83 & 4.00 & 3.67 & 3.83 & 3.94 & 4.04 \\
\hline 14 & Canada & 3.87 & 3.71 & 4.03 & 3.24 & 3.99 & 4.01 & 4.41 \\
\hline 15 & United States & 3.86 & 3.68 & 4.15 & 3.21 & 3.92 & 4.17 & 4.19 \\
\hline 16 & Denmark & 3.85 & 3.58 & 3.99 & 3.46 & 3.83 & 3.94 & 4.38 \\
\hline 17 & France & 3.84 & 3.63 & 4.00 & 3.30 & 3.87 & 4.01 & 4.37 \\
\hline 18 & Australia & 3.84 & 3.68 & 3.78 & 3.78 & 3.77 & 3.87 & 4.16 \\
\hline 19 & Austria & 3.76 & 3.49 & 3.68 & 3.78 & 3.70 & 3.83 & 4.08 \\
\hline 20 & Taiwan & 3.71 & 3.35 & 3.62 & 3.64 & 3.65 & 4.04 & 3.95 \\
\hline
\end{tabular}

Source: The World Bank LPI ranking

Table 4. A summary of the cost components mentioned in the literature

\begin{tabular}{|c|c|c|c|c|c|c|c|c|c|}
\hline $\begin{array}{l}\text { Publication } \\
\text { (Year of publication) }\end{array}$ & 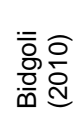 & $\begin{array}{l}\text { 응 } \\
\text { ळᄋ워 }\end{array}$ & 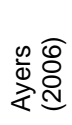 & 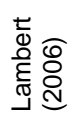 & 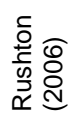 & 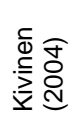 & 産 & 奒辰 & $\varliminf_{ઢ}$ \\
\hline Transportation costs & $\checkmark$ & $\checkmark$ & $\checkmark$ & $\checkmark$ & $\checkmark$ & $\checkmark$ & $\checkmark$ & $\checkmark$ & 8 \\
\hline Inventory-carrying costs & $\checkmark$ & $\checkmark$ & $\checkmark$ & $\checkmark$ & $\checkmark$ & & $\checkmark$ & $\checkmark$ & 7 \\
\hline Warehousing costs & $\checkmark$ & $\checkmark$ & $\checkmark$ & $\checkmark$ & $\checkmark$ & $\checkmark$ & $\checkmark$ & & 7 \\
\hline Packaging costs & & & $\checkmark$ & & $\checkmark$ & $\checkmark$ & $\checkmark$ & & 4 \\
\hline Administration costs & & & & & $\checkmark$ & & $\checkmark$ & & 2 \\
\hline Customer service & & & & $\checkmark$ & & $\checkmark$ & & & 2 \\
\hline Order processing/information & $\checkmark$ & & & $\checkmark$ & & & & & 2 \\
\hline Associated labour & & & $\checkmark$ & & & & & & 1 \\
\hline Capital costs of goods in transit & $\checkmark$ & & & & & & & & 1 \\
\hline Communication & & & & & & & & $\sqrt{ }$ & 1 \\
\hline Consultancy & & & & & & 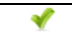 & & & 1 \\
\hline Cost of damage during transit & $\checkmark$ & & & & & & & & 1 \\
\hline Fixed costs & & & & & & & $\checkmark$ & & 1 \\
\hline Logistics technology & & & & & & $\checkmark$ & & & 1 \\
\hline Lot quantity & & & & $\checkmark$ & & & & & 1 \\
\hline Manufacturing & & & & & & $\checkmark$ & & & 1 \\
\hline Procurement & & & & & & $\checkmark$ & & & 1 \\
\hline Purchased materials & & & $\checkmark$ & & & & & & 1 \\
\hline Quality control & & & & & & $\checkmark$ & & & 1 \\
\hline Recycling logistics & & & & & & $\checkmark$ & & & 1 \\
\hline Reverse logistics & & & & & & $\checkmark$ & & & 1 \\
\hline Stock-out costs & $\checkmark$ & & & & & & & & 1 \\
\hline Trade costs & & & & & & & & $\checkmark$ & 1 \\
\hline Value-added services & & & & & & $\checkmark$ & & & 1 \\
\hline
\end{tabular}


Table 5. A summary of the cost components mentioned in scientific articles

\begin{tabular}{|c|c|c|c|c|c|c|c|c|c|c|}
\hline $\begin{array}{r}\text { Publication } \\
\text { (Year of publication) }\end{array}$ & 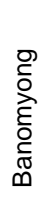 & 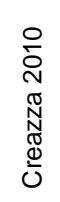 & $\begin{array}{l}\stackrel{8}{0} \\
\stackrel{2}{0} \\
\bar{o} \\
\overline{0}\end{array}$ & 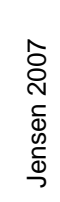 & 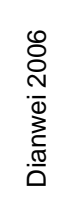 & 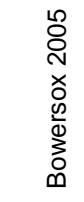 & $\begin{array}{l}\text { O } \\
\text { D } \\
\text { Oे } \\
\stackrel{D}{N}\end{array}$ & 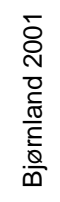 & $\begin{array}{l}\infty \\
\infty \\
o \\
\frac{0}{2} \\
\stackrel{0}{2} \\
\gtrless\end{array}$ & $\sum_{\text {क }}$ \\
\hline \multicolumn{11}{|c|}{ Cost components } \\
\hline Transportation costs & $\checkmark$ & $\checkmark$ & $\checkmark$ & $\checkmark$ & & & $\checkmark$ & $\checkmark$ & $\checkmark$ & 7 \\
\hline Warehousing costs & $\checkmark$ & & $\checkmark$ & $\checkmark$ & & & $\checkmark$ & & $\checkmark$ & 5 \\
\hline Inventory-carrying costs & $\checkmark$ & $\checkmark$ & & $\checkmark$ & & & $\checkmark$ & & & 4 \\
\hline Administration costs & & & $\checkmark$ & $\checkmark$ & & & $\checkmark$ & & & 3 \\
\hline Risk and Damage & & & & & & & & $\checkmark$ & $\checkmark$ & 3 \\
\hline Insurance & & & & & & & & $\checkmark$ & $\checkmark$ & 2 \\
\hline Packaging costs & $\checkmark$ & & & & & & $\checkmark$ & & & 2 \\
\hline Tied capital costs (transportation) & & & & & & & & $\checkmark$ & $\checkmark$ & 2 \\
\hline $\begin{array}{l}\text { Cost of commodities space } \\
\text { movement }\end{array}$ & & & & & $\checkmark$ & & & & & 1 \\
\hline Customer service & $\checkmark$ & & & & & & & & & 1 \\
\hline Customs & & & & & & & $\checkmark$ & & & 1 \\
\hline Design, restructure and option costs & & & & & $\checkmark$ & & & & & 1 \\
\hline Forecasting & $\checkmark$ & & & & & & & & & 1 \\
\hline Handling & & $\checkmark$ & & & & & & & & 1 \\
\hline Indirect logistics costs & & & & $\checkmark$ & & & & & & 1 \\
\hline Information processing & $\checkmark$ & & & & & & & & & 1 \\
\hline Order processing & & $\checkmark$ & & & & & & & & 1 \\
\hline Other costs & & & & & $\checkmark$ & & & & & 1 \\
\hline Permission losses & & & & & $\checkmark$ & & & & & 1 \\
\hline Procurement & $\checkmark$ & & & & & & & & & 1 \\
\hline Substance consumption & & & & & $\checkmark$ & & & & & 1 \\
\hline Returned goods & $\checkmark$ & & & & & & & & & 1 \\
\hline Wages, bonuses, allowances & & & & & $\checkmark$ & & & & & 1 \\
\hline \multicolumn{11}{|c|}{ Logistics costs and the measurement scale } \\
\hline$\%$ of sales / turnover & $\checkmark$ & & & $\vartheta$ & & & & & & \\
\hline$\%$ of GDP & & & & & $\checkmark$ & 13.8 & & & & \\
\hline Actual costs (bn. EUR) & & $\checkmark$ & & & & 6090 & $\checkmark$ & & $\checkmark$ & \\
\hline Other & & & & & & & & $\checkmark$ & $\checkmark$ & \\
\hline
\end{tabular}




\section{Figure 10. Logistics Costs Positioning}

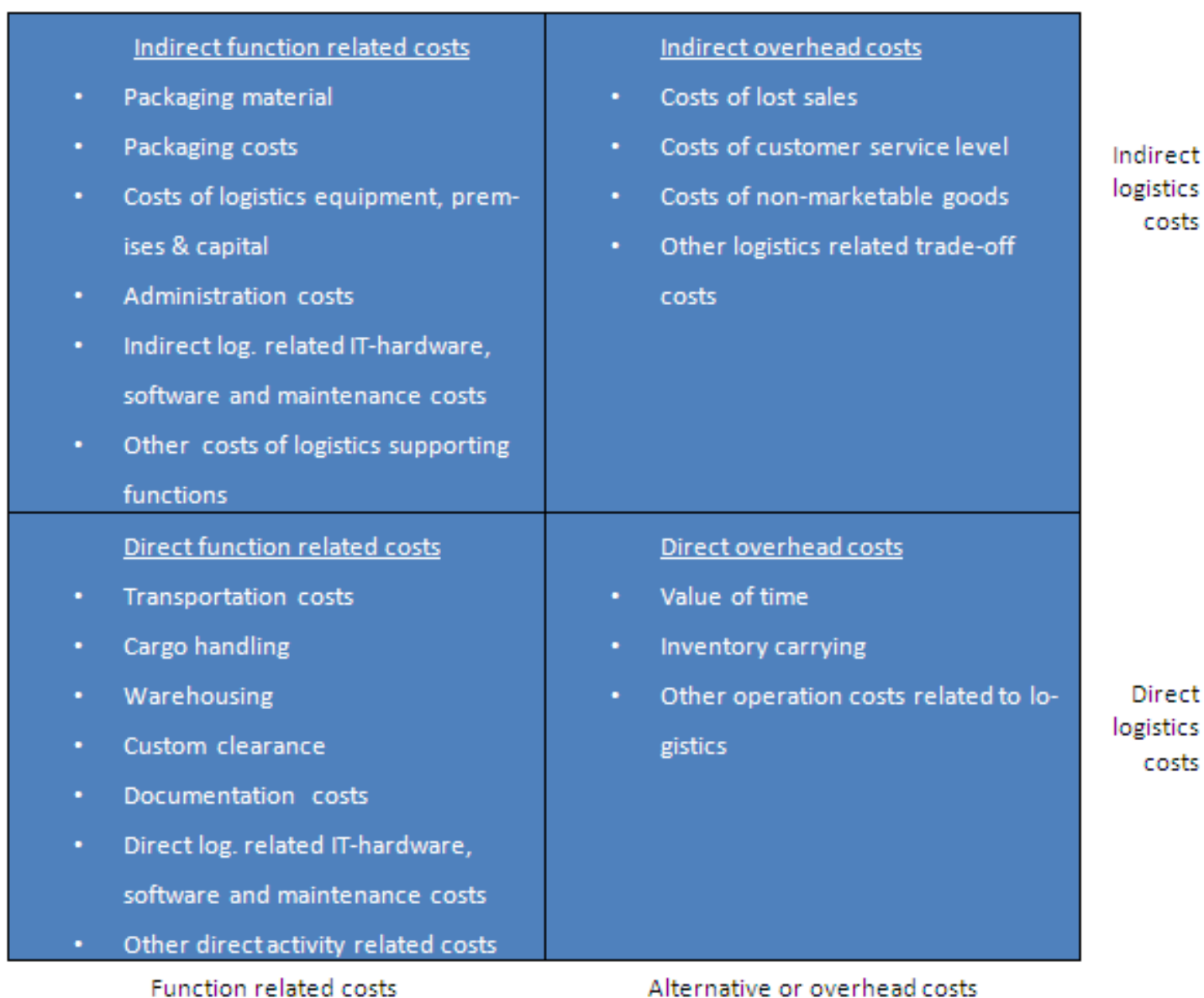

Source: derived from Ojala et al. 2009, 24 
Figure 11. Logistics Market Volumes in European Countries, 2005 and 2010, bn. Euro

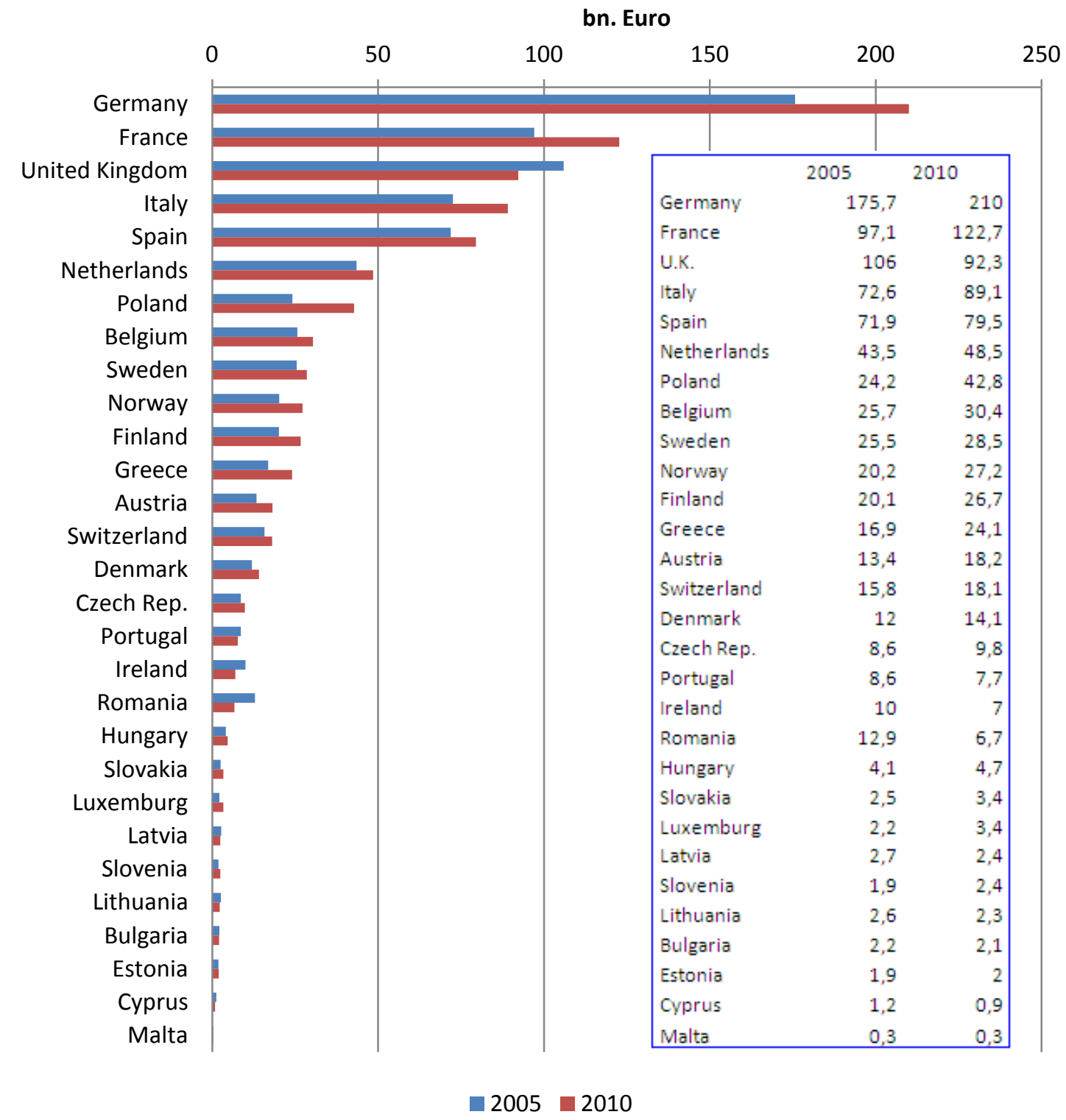

Source: Klaus \& Kille 2007, 45-56; Klaus et al. 2011, 1 
Figure 12. Logistics Costs in the United States between 1985-2010 as a percentage of GDP and as absolute costs, trillion USD

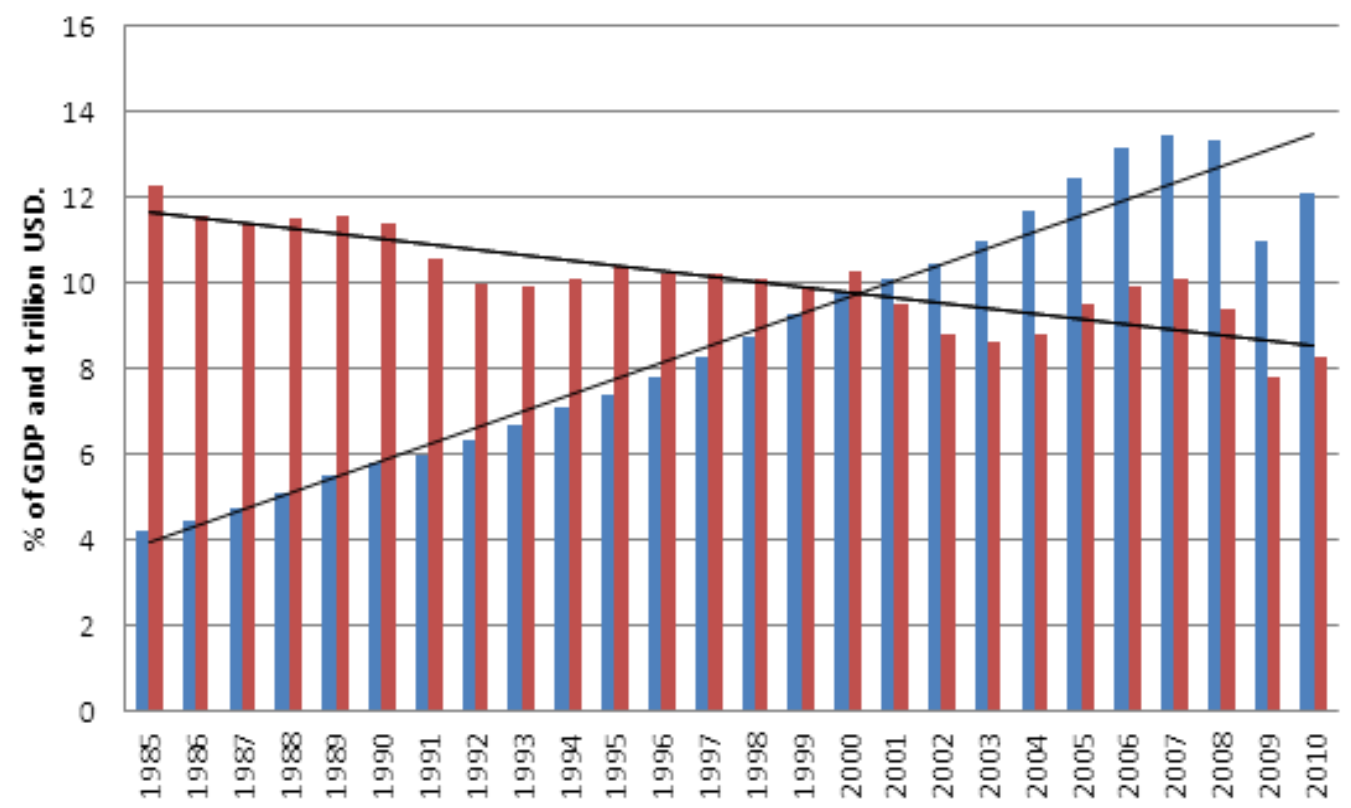

Source: CSCMP's 19th Annual State of Logistics Report 2008, 30; Wilson 2011, 12-13

Figure 13. Total Logistics Costs per Cost Component in South Africa, 2003-2009, as a percentage of GDP

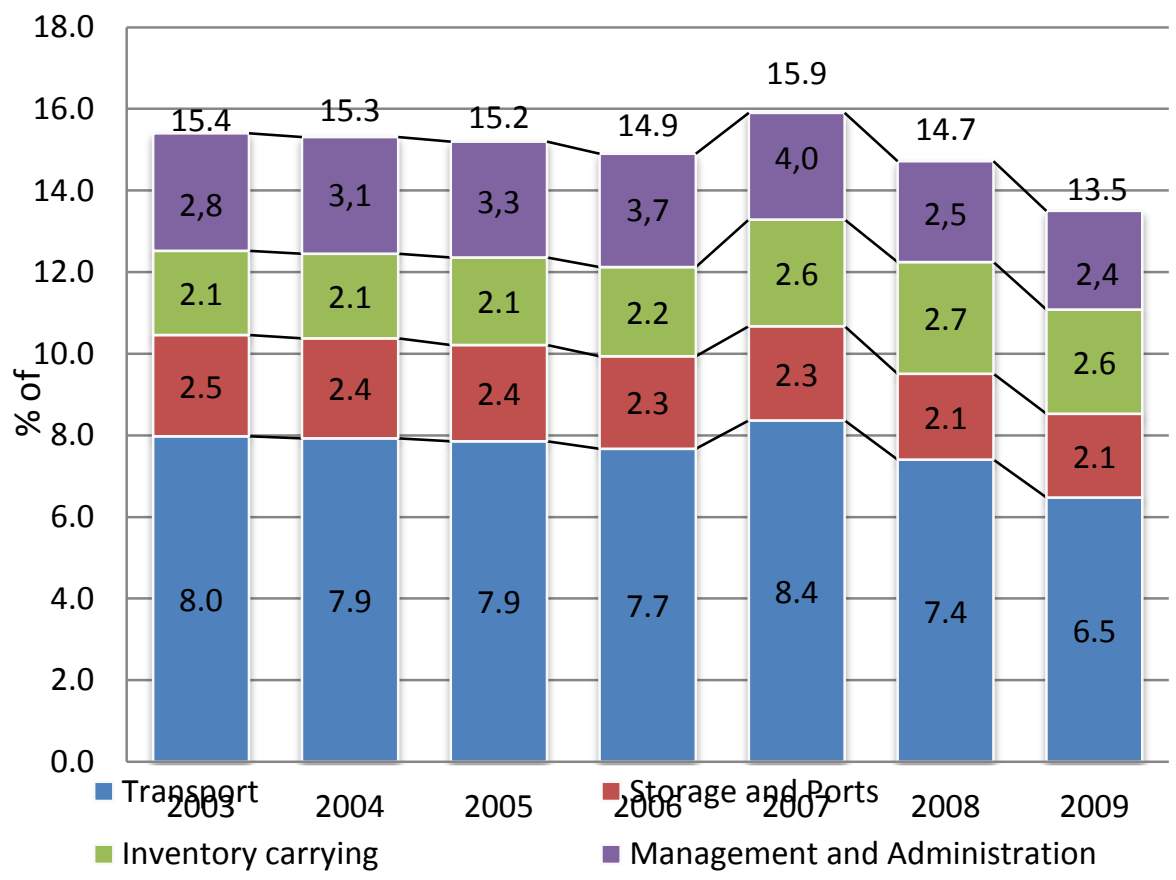

Source: State of Logistics Survey for South Africa 2010, 19 
Figure 14. Logistics Costs in China, 2006-2010 in bn. EUR

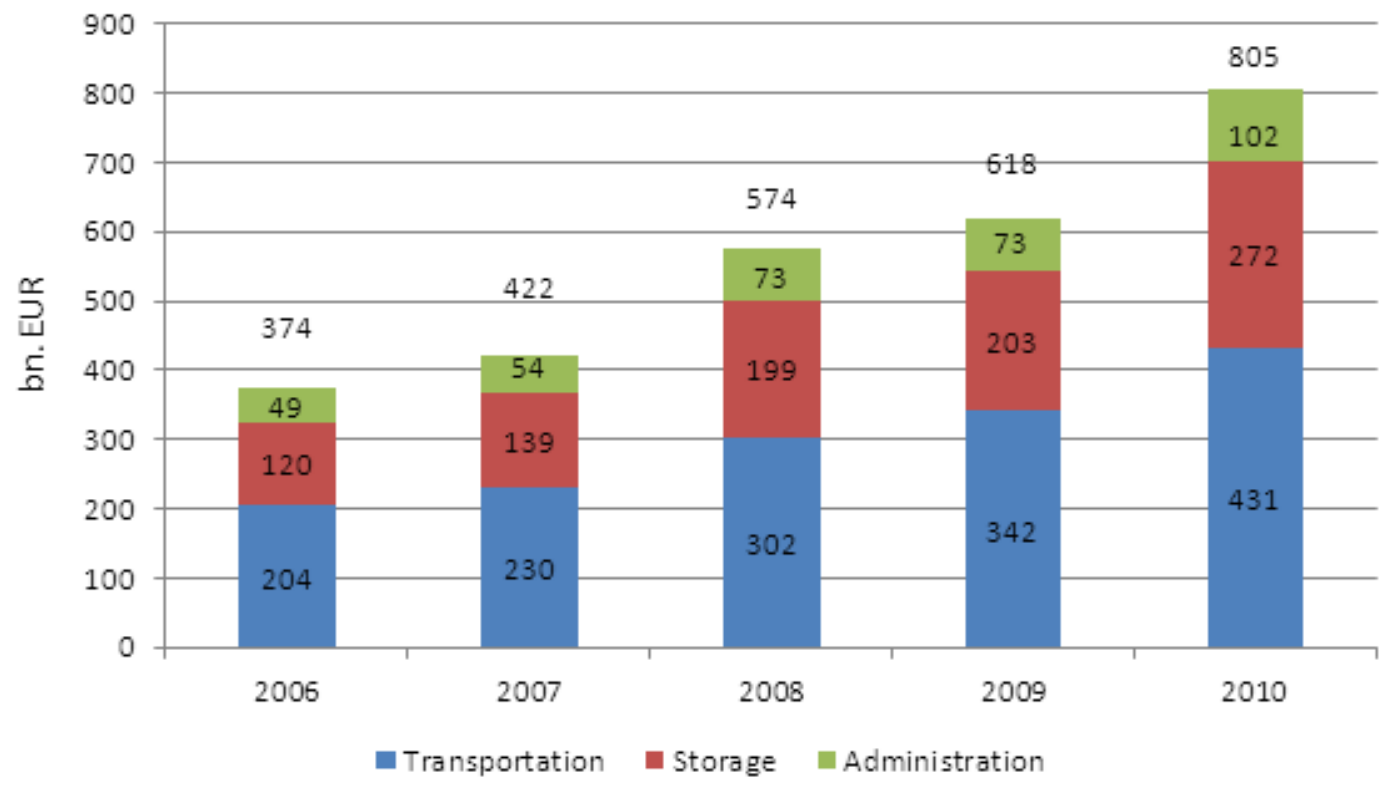

Sources: CFLP 2011; CFLP 2010; CFLP 2009; CFLP 2008; CFLP 2006

Figure 15. The volume of logistics markets in Switzerland, 2006-2009 bn. CHF

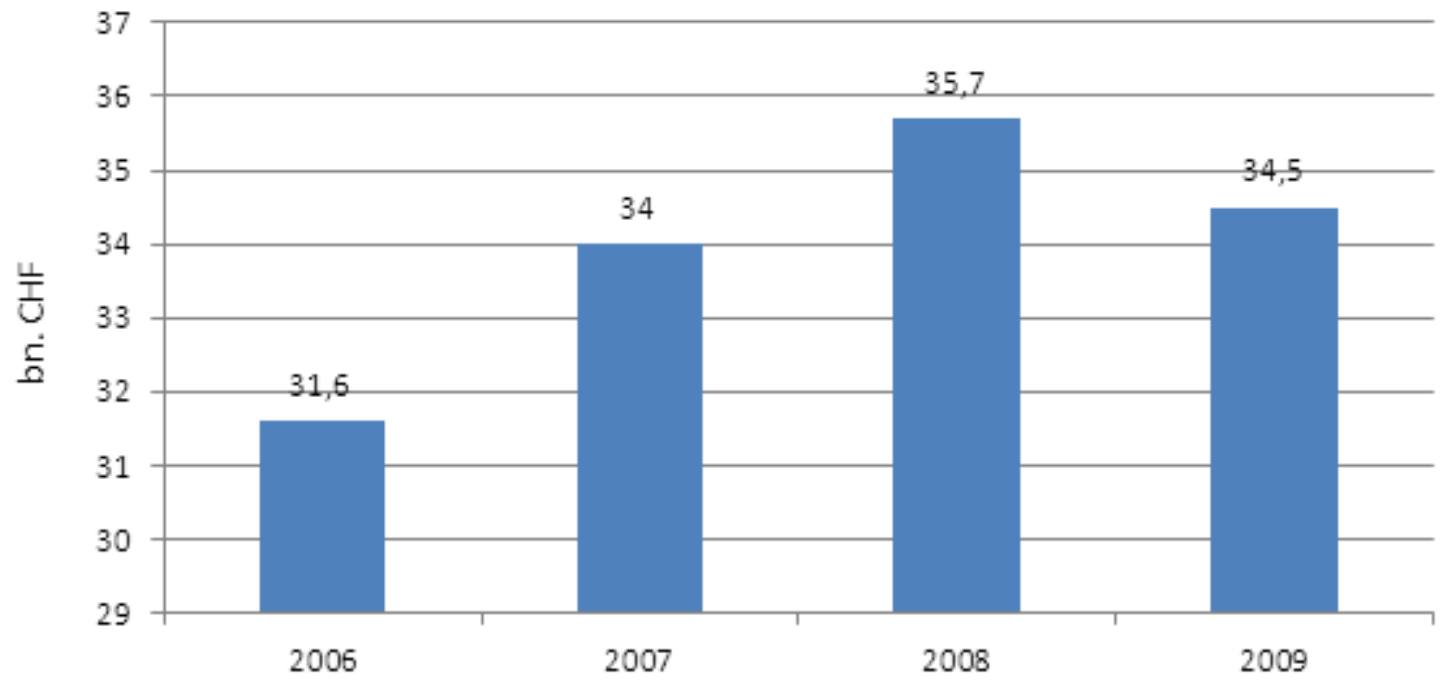

\begin{tabular}{|l|r|r|r|r|r|r|r|r|}
\hline \multicolumn{10}{|c|}{ Currency exchange rate EUR-CHF } \\
\hline Year & 2012 & 2011 & 2010 & 2009 & 2008 & 2007 & 2006 & 2005 \\
\hline Rate & 1,2155 & 1,25 & 1,4873 & 1,4874 & 1,6529 & 1,6104 & 1,5536 & 1,5444 \\
\hline
\end{tabular}

Source: Factsheet zur Logistikmarktstudie 2011: Volumen Logistikmarkt Schweiz 
Figure 16. Thailand's Logistics Costs from 2000 to 2008 as absolute costs

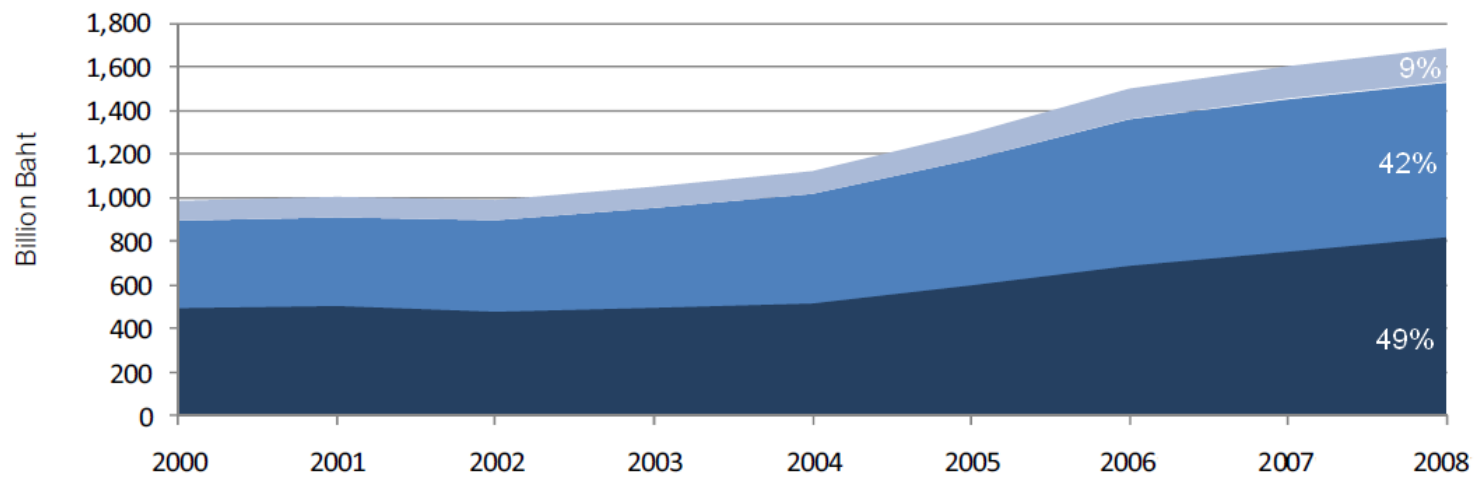

Transport Cost Inventory Holding Cost

Logistics Administration Cost

\begin{tabular}{|l|r|r|r|r|r|r|r|r|r|}
\hline \multicolumn{10}{|c|}{ Currency exchange rate EUR-THB } \\
\hline Year & 2008 & 2007 & 2006 & 2005 & 2004 & 2003 & 2002 & 2001 & 2000 \\
\hline Rate & 44,013 & 47,462 & 48,516 & 48,516 & 48,516 & 48,516 & 48,516 & 48,516 & 48,516 \\
\hline
\end{tabular}

Source: Thailand Logistics Report 2008, 5)

Figure 17. Logistics Costs in Korea as a percentage of GDP

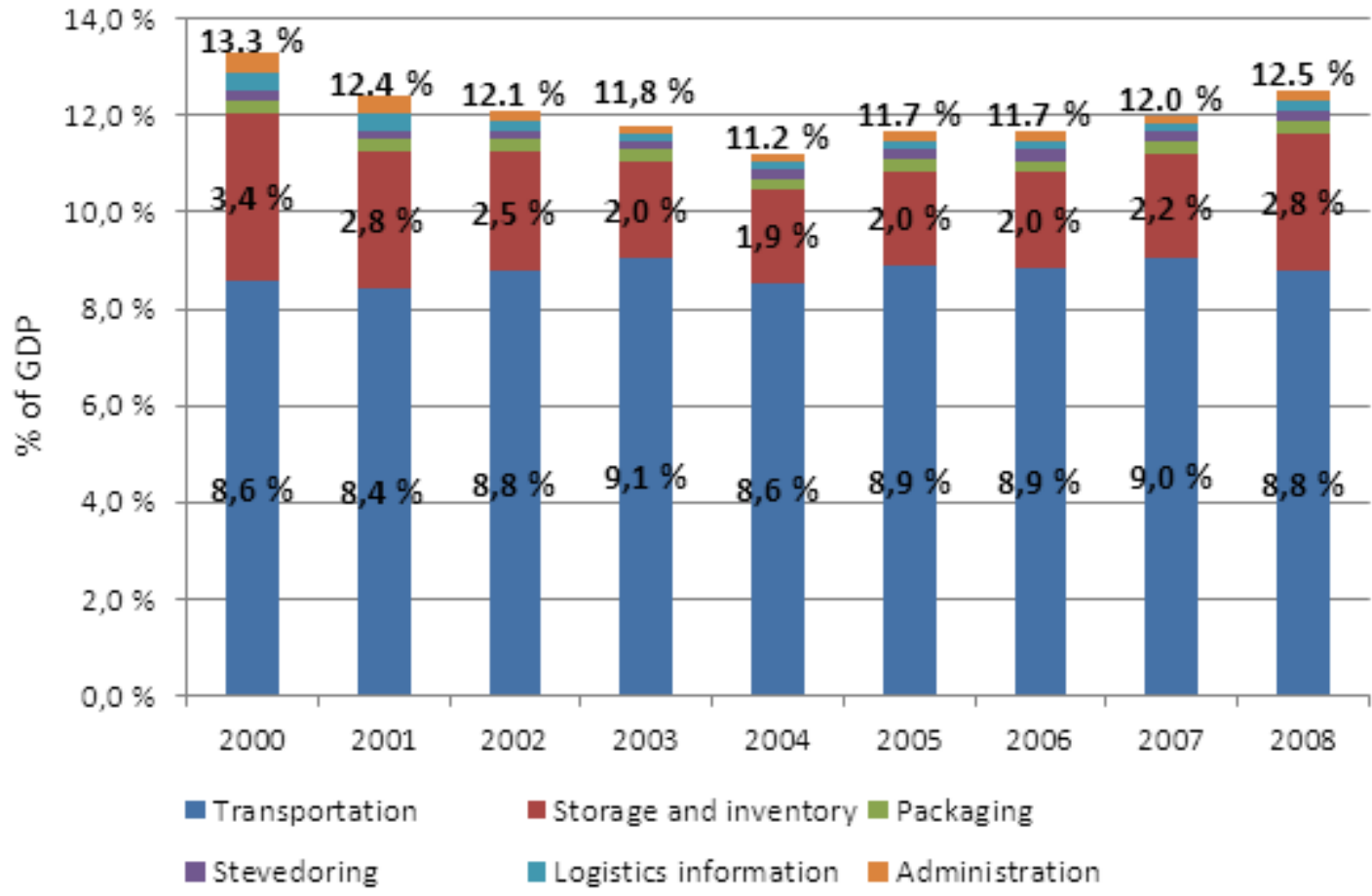

Sources: KOTI 2010, 34-35 
Figure 18. Components and Data Sources for Evaluating Logistics Costs in the Republic of Korea

\begin{tabular}{|c|c|c|c|c|}
\hline Items & Class I & Class II & Class III & Sources \\
\hline \multirow{17}{*}{ Transportation } & \multirow{2}{*}{ Rail } & \multicolumn{2}{|c|}{ Freight } & \multirow{2}{*}{$\begin{array}{c}\text { Railway Statistics Annual } \\
\text { Report }\end{array}$} \\
\hline & & \multicolumn{2}{|c|}{ Mini-load } & \\
\hline & \multirow{7}{*}{ Road } & \multirow{5}{*}{ Public } & Route & \multirow{5}{*}{$\begin{array}{c}\text { Transportation Industry } \\
\text { Statistical Investigation } \\
\text { Report }\end{array}$} \\
\hline & & & Special & \\
\hline & & & Zone & \\
\hline & & & Contract & \\
\hline & & & Other & \\
\hline & & \multirow[b]{2}{*}{ Private } & Operations & Own Calculation \\
\hline & & & Tolls & $\begin{array}{c}\text { Korea Highway } \\
\text { Corporation }\end{array}$ \\
\hline & \multirow{4}{*}{ Water } & \multicolumn{2}{|c|}{ Inland port } & Transportation Incustry \\
\hline & & \multirow{2}{*}{ Ocean } & Domestic & Statistical Investigation \\
\hline & & & Foreigner & Report; Korea Vessel \\
\hline & & \multicolumn{2}{|c|}{ Inland water } & Agency Association \\
\hline & \multirow{3}{*}{ Air } & \multicolumn{2}{|c|}{ National } & Annual Report of Ministry \\
\hline & & \multirow{2}{*}{ International } & Domestic & of Construction \& \\
\hline & & & Foreigner & Transportation \\
\hline & Agency & \multicolumn{2}{|c|}{ Agency } & $\begin{array}{l}\text { Transportation Industry } \\
\text { Statistical Investigation } \\
\text { Report }\end{array}$ \\
\hline \multirow{8}{*}{ Inventory Carrying } & \multirow{6}{*}{ Custody } & \multirow{5}{*}{ Public } & Ordinary & \multirow{5}{*}{$\begin{array}{c}\text { Transportation Industry } \\
\text { Statistical Investigation } \\
\text { Report }\end{array}$} \\
\hline & & & Cold storage & \\
\hline & & & Dangerous & \\
\hline & & & Agricultural & \\
\hline & & & Other & \\
\hline & & \multicolumn{2}{|c|}{ Private } & $\begin{array}{l}\text { Korea Chamber of } \\
\text { Commerce \& Industry }\end{array}$ \\
\hline & \multicolumn{3}{|c|}{ Inventory holding } & $\begin{array}{c}\text { Enterprise Management } \\
\text { Analysis }\end{array}$ \\
\hline & \multicolumn{3}{|c|}{ Breakage } & $\begin{array}{c}\text { Korea Chamber of } \\
\text { Commerce \& Industry }\end{array}$ \\
\hline \multirow{2}{*}{ Packing } & \multicolumn{3}{|c|}{ Corrugated cardboard } & $\mathrm{KCCA}$ \\
\hline & \multicolumn{3}{|c|}{ Pallet } & $\begin{array}{l}\text { Korea Chamber of } \\
\text { Commerce \&Industry }\end{array}$ \\
\hline \multirow{2}{*}{$\begin{array}{c}\text { Handling and } \\
\text { Lading/ Unloading }\end{array}$} & \multicolumn{3}{|c|}{ Land and Air } & Transportation Industry \\
\hline & \multicolumn{3}{|c|}{ Water } & $\begin{array}{c}\text { Statistical Investigation } \\
\text { Report }\end{array}$ \\
\hline Information & & & & $\begin{array}{l}\text { Korea Chamber of } \\
\text { Commerce \& Industry }\end{array}$ \\
\hline Administration & & & & $\begin{array}{l}\text { Korea Chamber of } \\
\text { Commerce \& Industry }\end{array}$ \\
\hline
\end{tabular}

Source: UN: Commercial Development of Regional Ports as Logistics Centres, 89; KOTI 2010, 11 
Table 6. Logistics Costs in Sweden, 1997-2005, bn. SEK

\begin{tabular}{llllll}
\hline Year & $\begin{array}{l}\text { Direct } \\
\text { transport } \\
\text { costs }\end{array}$ & $\begin{array}{l}\text { Inventory } \\
\text { carrying } \\
\text { costs }\end{array}$ & $\begin{array}{l}\text { Warehousing } \\
\text { costs }\end{array}$ & $\begin{array}{c}\text { Administration } \\
\text { costs }\end{array}$ & $\begin{array}{l}\text { Total } \\
\text { costs }\end{array}$ \\
\hline 1997 & 49.8 & 109.3 & 5.9 & 30.6 & 195.5 \\
1998 & 56.9 & 112.4 & 4.5 & 37.4 & 211.1 \\
1999 & 61.9 & 114.3 & 4.4 & 38.7 & 219.3 \\
2000 & 72.5 & 129.7 & 4.9 & 43.1 & 250.2 \\
2001 & 77.4 & 130.1 & 5.3 & 44.8 & 257.6 \\
2002 & 74.6 & 122.5 & 4.9 & 42.2 & 244.2 \\
2003 & 74.2 & 86.8 & 5.3 & 39.4 & 205.7 \\
2004 & 77.7 & 89.1 & 5.6 & 40.2 & 212.7 \\
2005 & 85.5 & 100.7 & 6.2 & 40.8 & 233.3 \\
\hline
\end{tabular}

\begin{tabular}{|l|r|r|r|r|r|r|r|r|r|}
\hline \multicolumn{10}{|c|}{ Currency exchange rate EUR-SEK } \\
\hline Year & 2005 & 2004 & 2003 & 2002 & 2001 & 2000 & 1999 & 1998 & 1997 \\
\hline Rate & 8,9758 & 9,05 & 9,127 & 9,2825 & 8,888 & 8,552 & 9,4696 & 9,4696 & 9,4696 \\
\hline
\end{tabular}

Source: Elger et al. 2008, 24)

Figure 19. The Logistics Costs of an Average Company as a Percentage of Sales, 2008-2010 according to the Davis Database

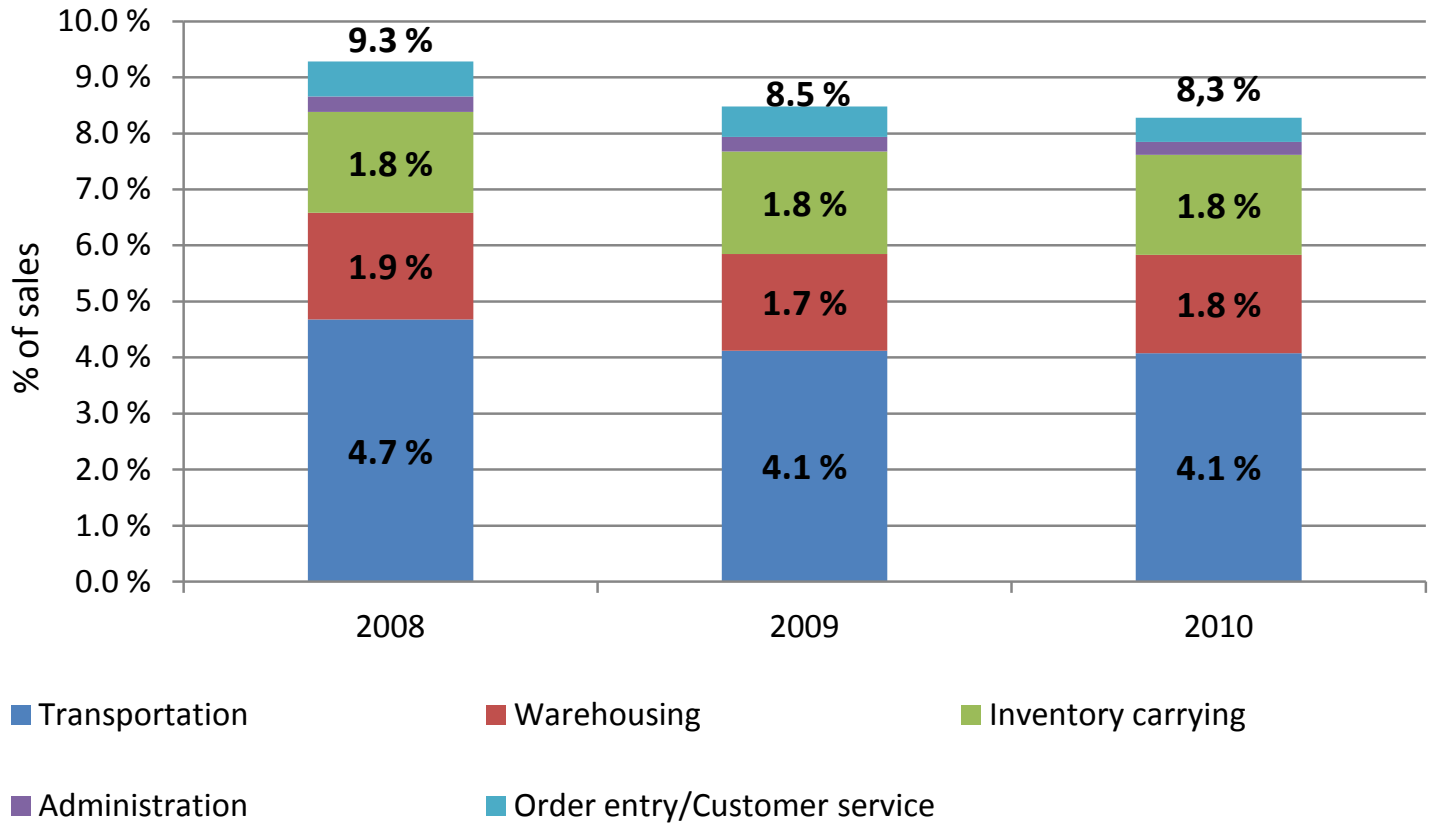

Source: Davis Database Presentation 2008, 16; Davis Database Presentation 2009, 13; Davis Database Presentation 2010, 9 
Figure 20. Levels of Logistics Cost Components in GMA Surveys, 2005 and 2008 as a Percentage of Total Logistics Costs

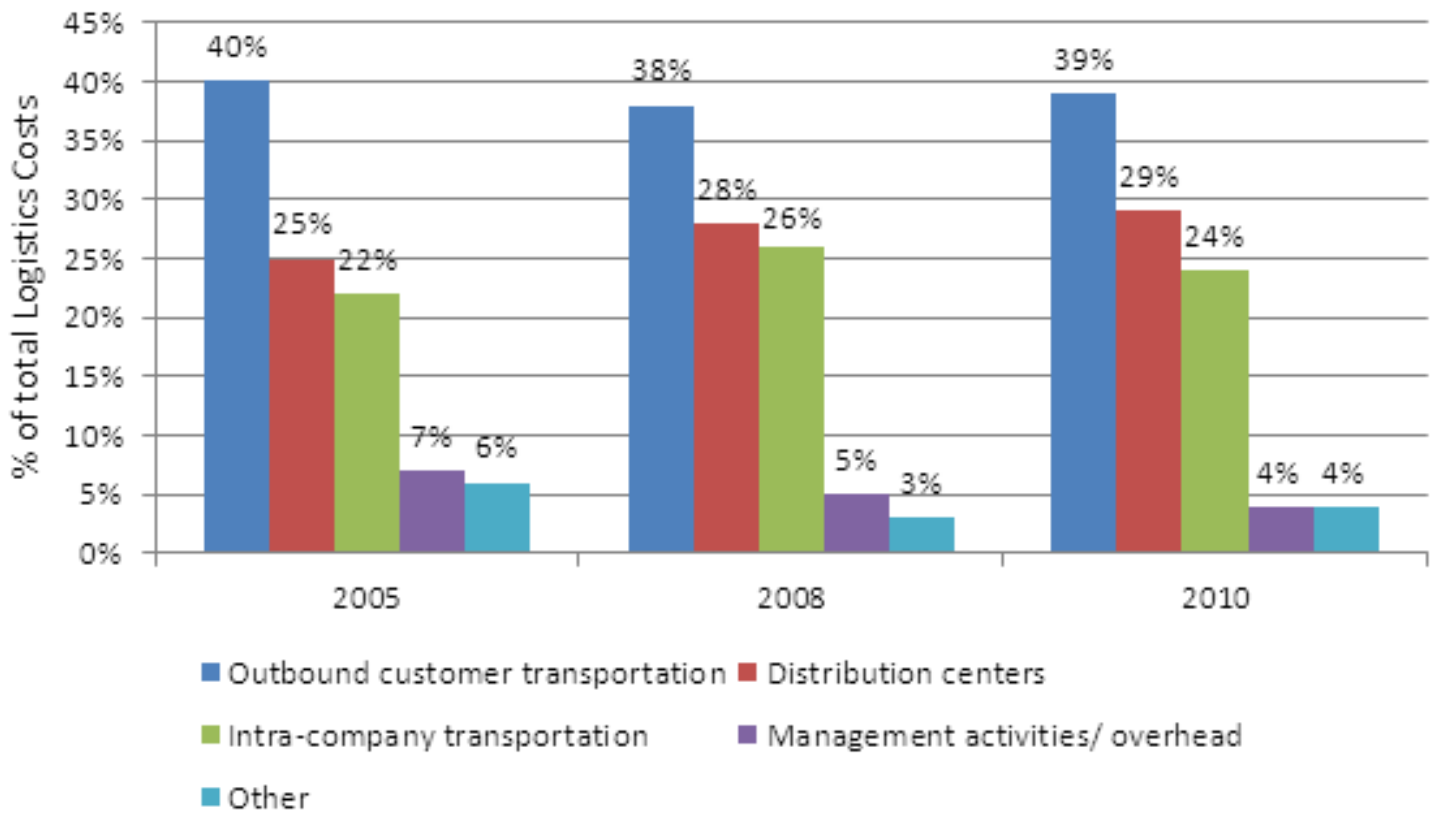

Source: The GMA Logistics Study 2008, 10; The GMA 2010 Logistics Benchmark Report, 10

Figure 21. The Development of Logistics Costs in Europe as a Percentage of Sales

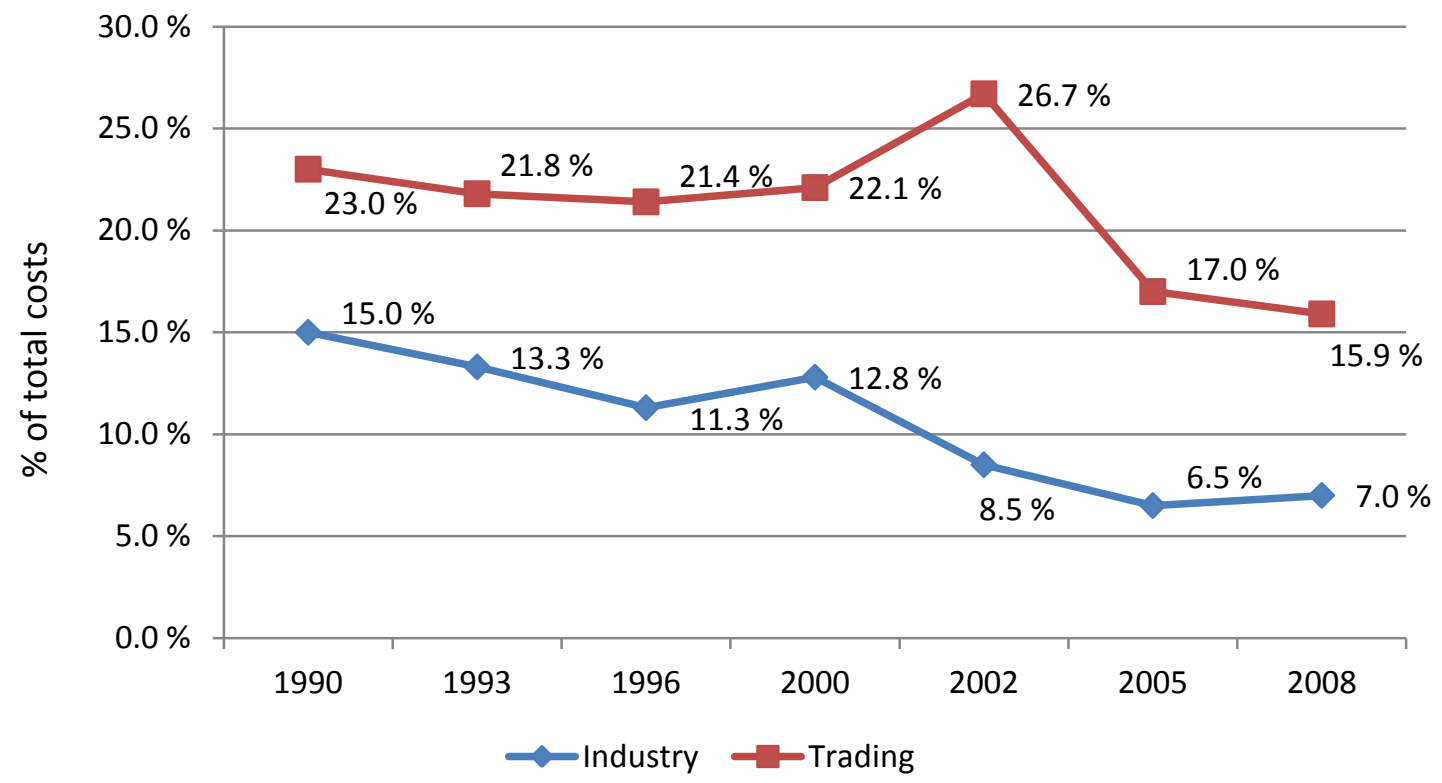

Source: Supply-Chain-Excellence in der globalen Wirtschaftskrise 2009 
Figure 22. The Development of Logistics Costs in Industry and Trading as a Percentage of Total Costs, 1990-2008

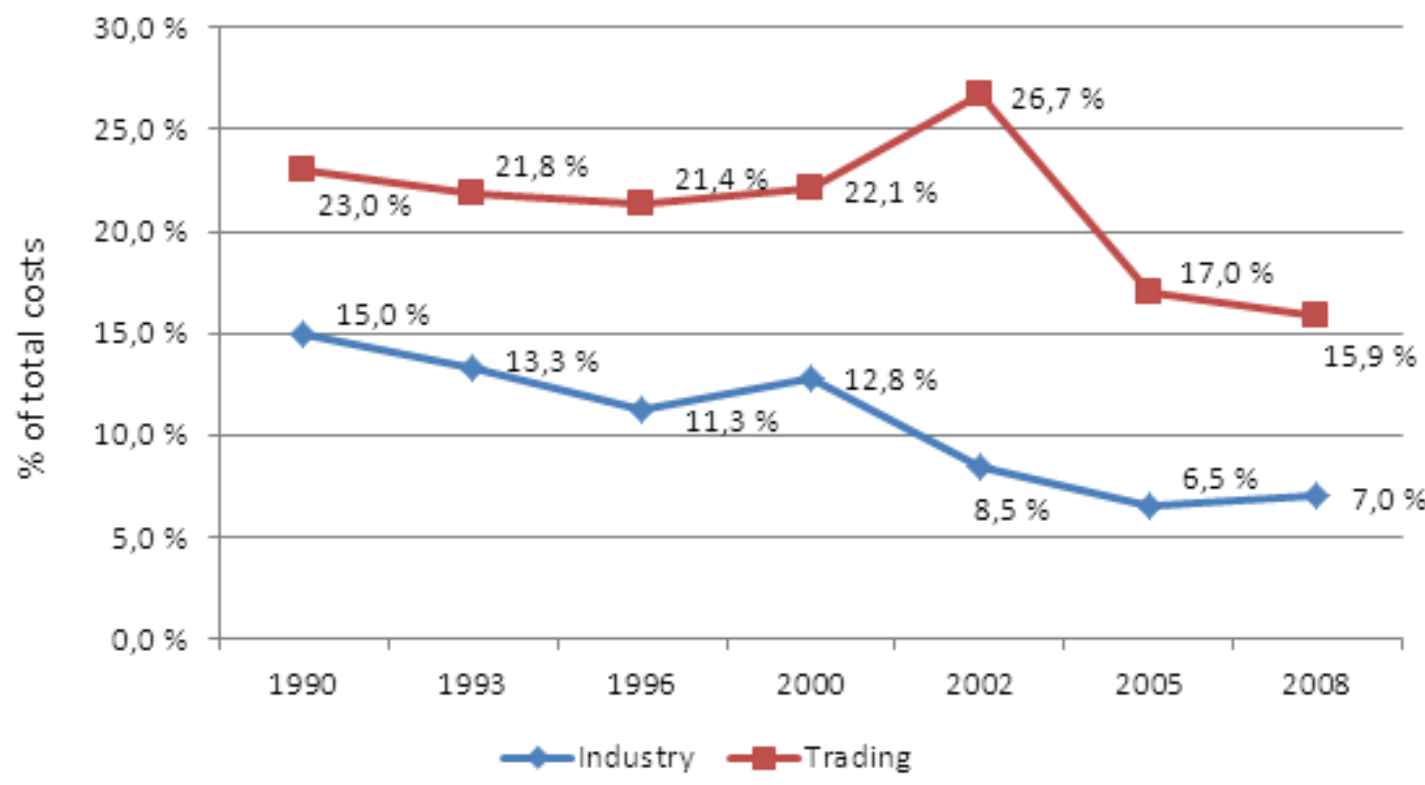

Source: traube \& Pfohl 2008, 47

Figure 23. Logistics Costs in BSR as a percentage of turnover, 2007

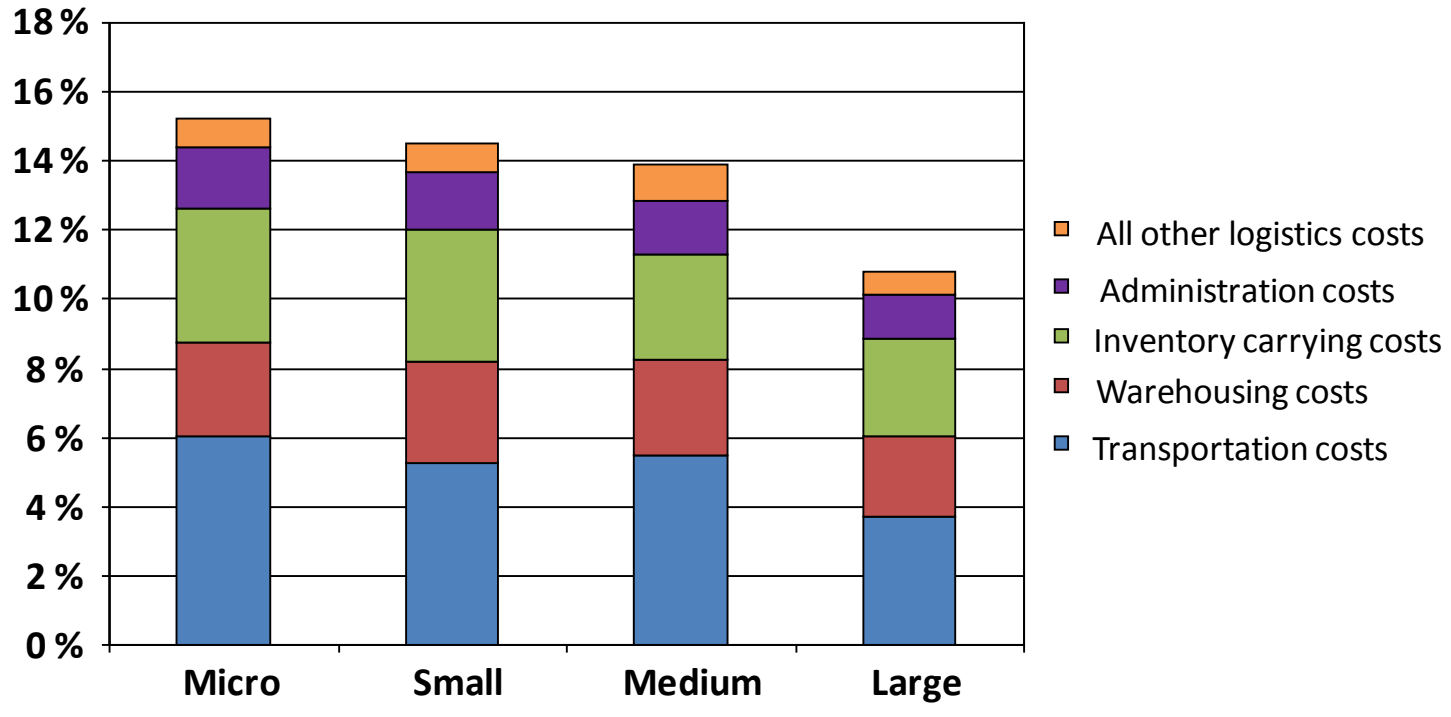

Source: Ojala et al. 2007, 38 
Figure 24. SCI Logistikbarometer

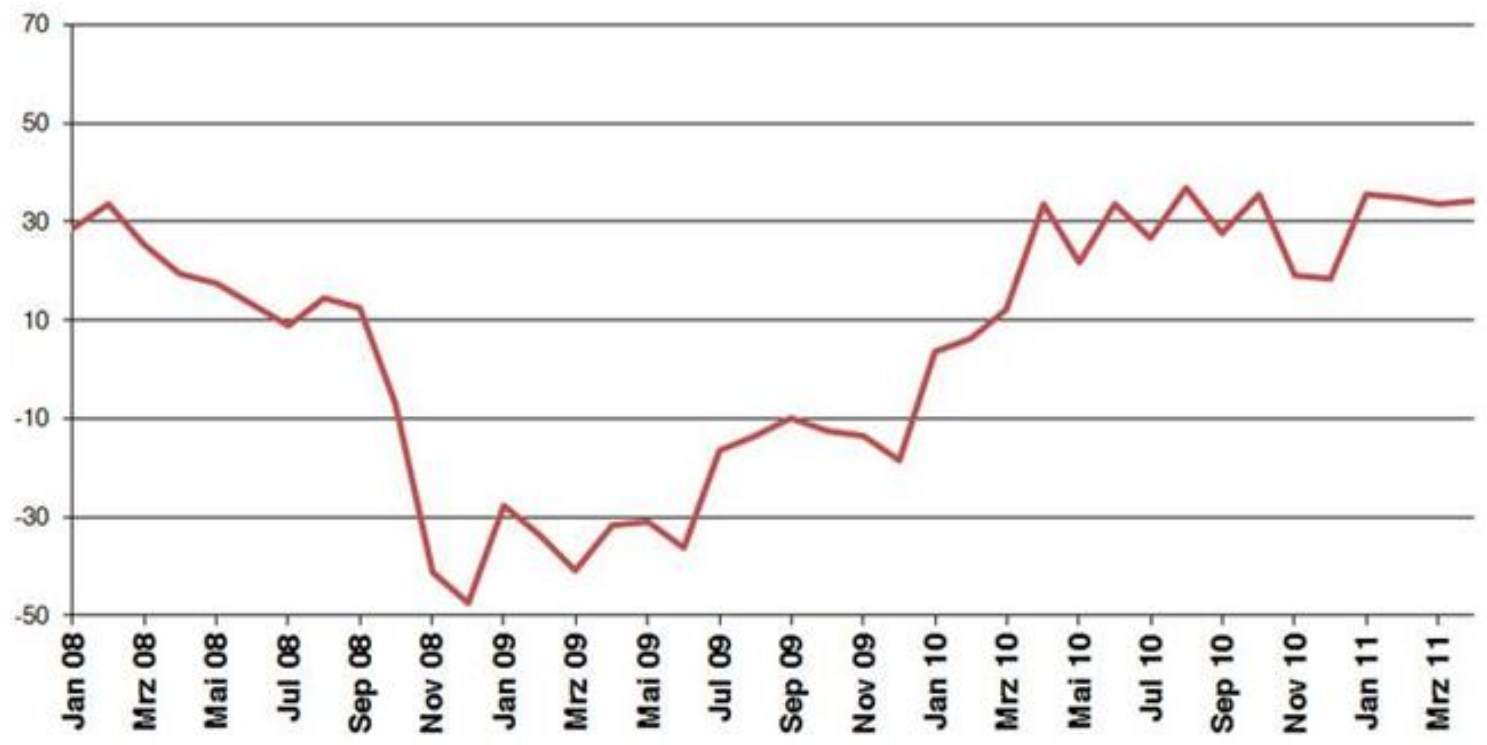

Source: SCI Verkehr Logistikbarometer July 2011, 2

Figure 25. Logistics Costs in Finnish Manufacturing and Trading Enterprises Weighted by Respondent and Industry Turnover as a Percentage of Total Turnover, 2005, 2008, and 2009

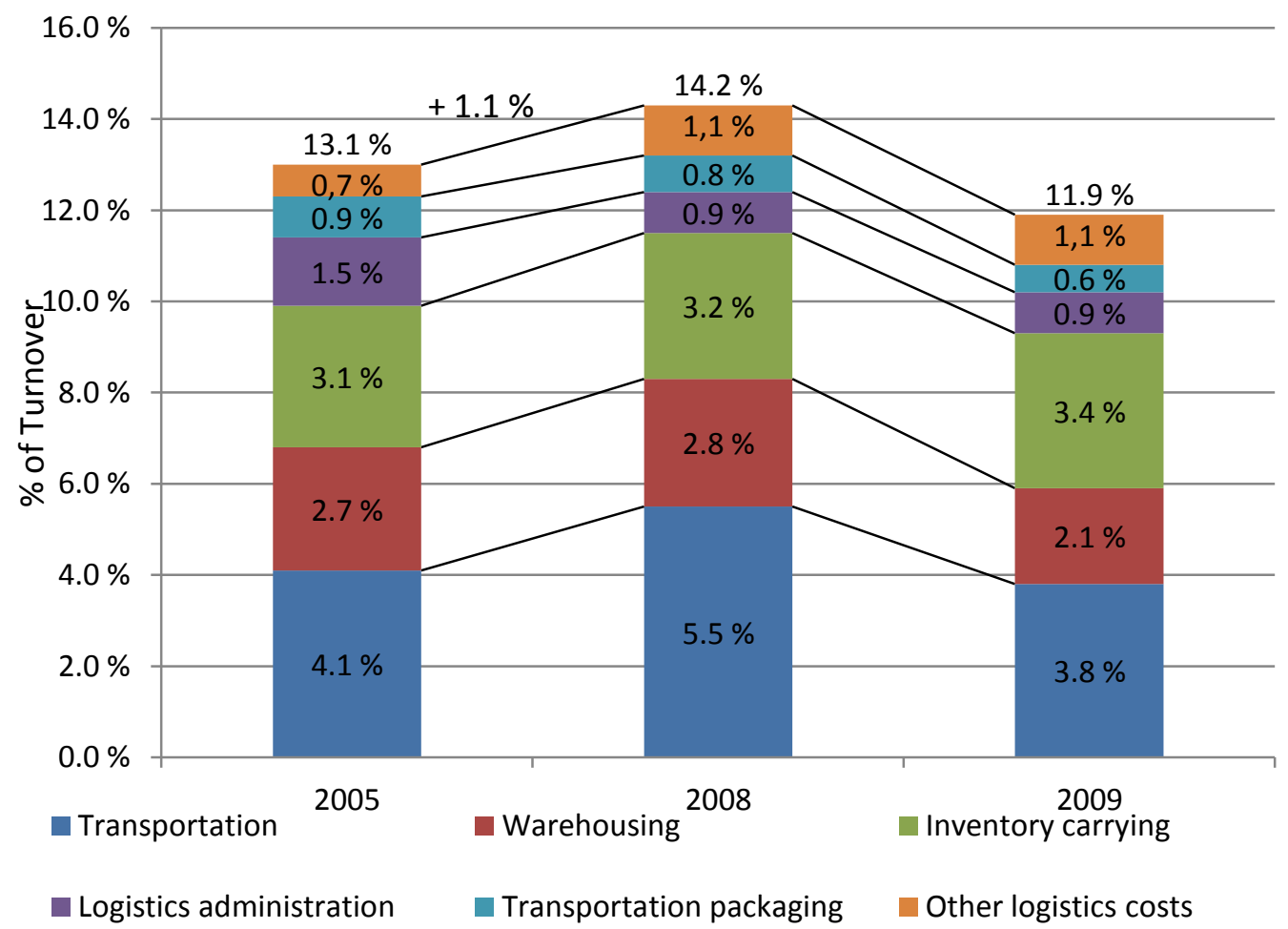

Sources: Finland State of Logistics reports 2006-2010: Naula et al. 2006; Solakivi et al. 2009; and Solakivi et al. 2010 
Figure 26. Logistics Costs in Norway, 2007 as a percentage of turnover in different industries

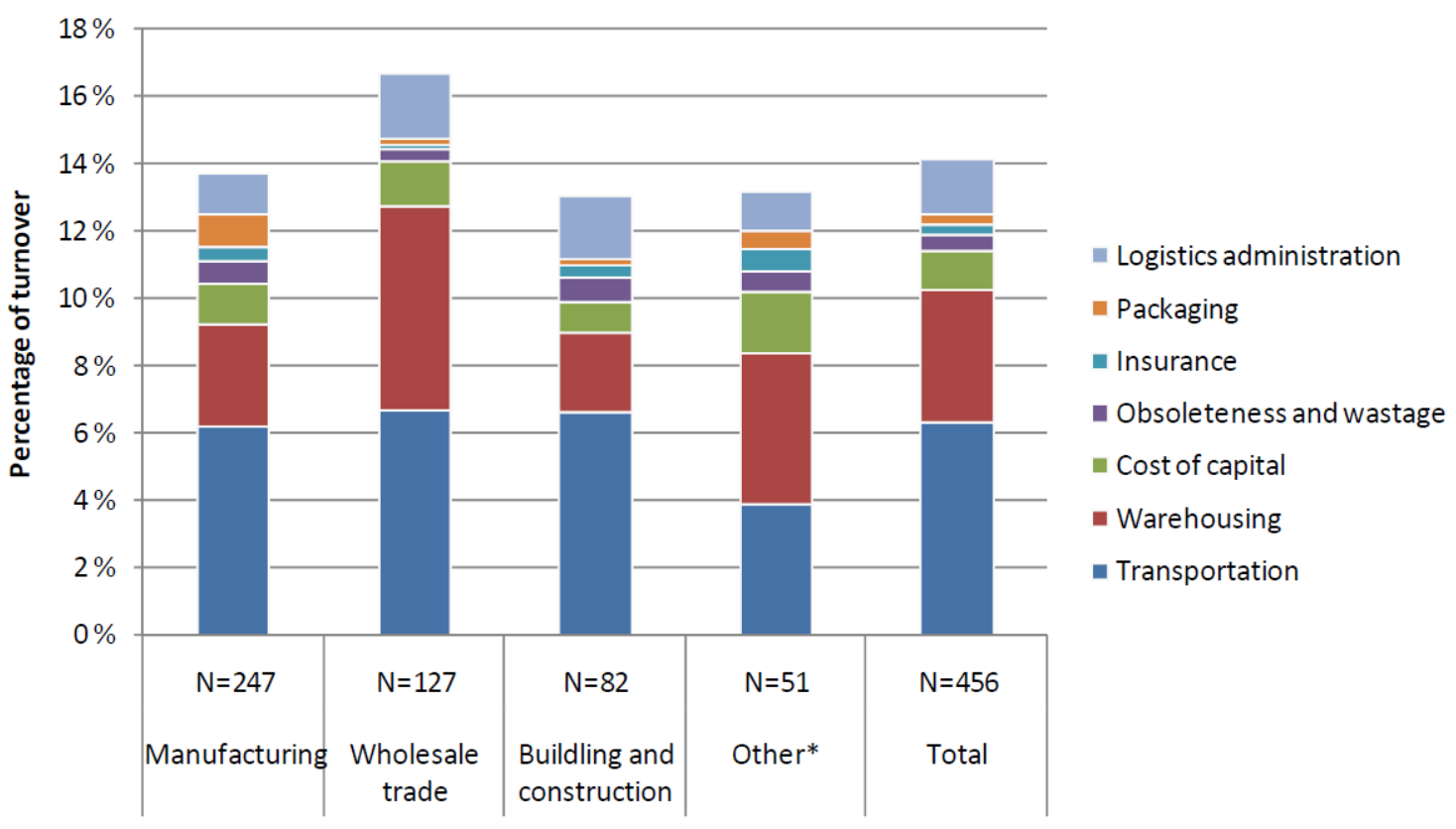

Source: Hovi \& Hansen 2010, iii

Figure 27. Logistics Costs per Cost Component in France, 2001-2008 as a Percentage of Total Logistics Costs, and Total Costs as a Percentage of Turnover

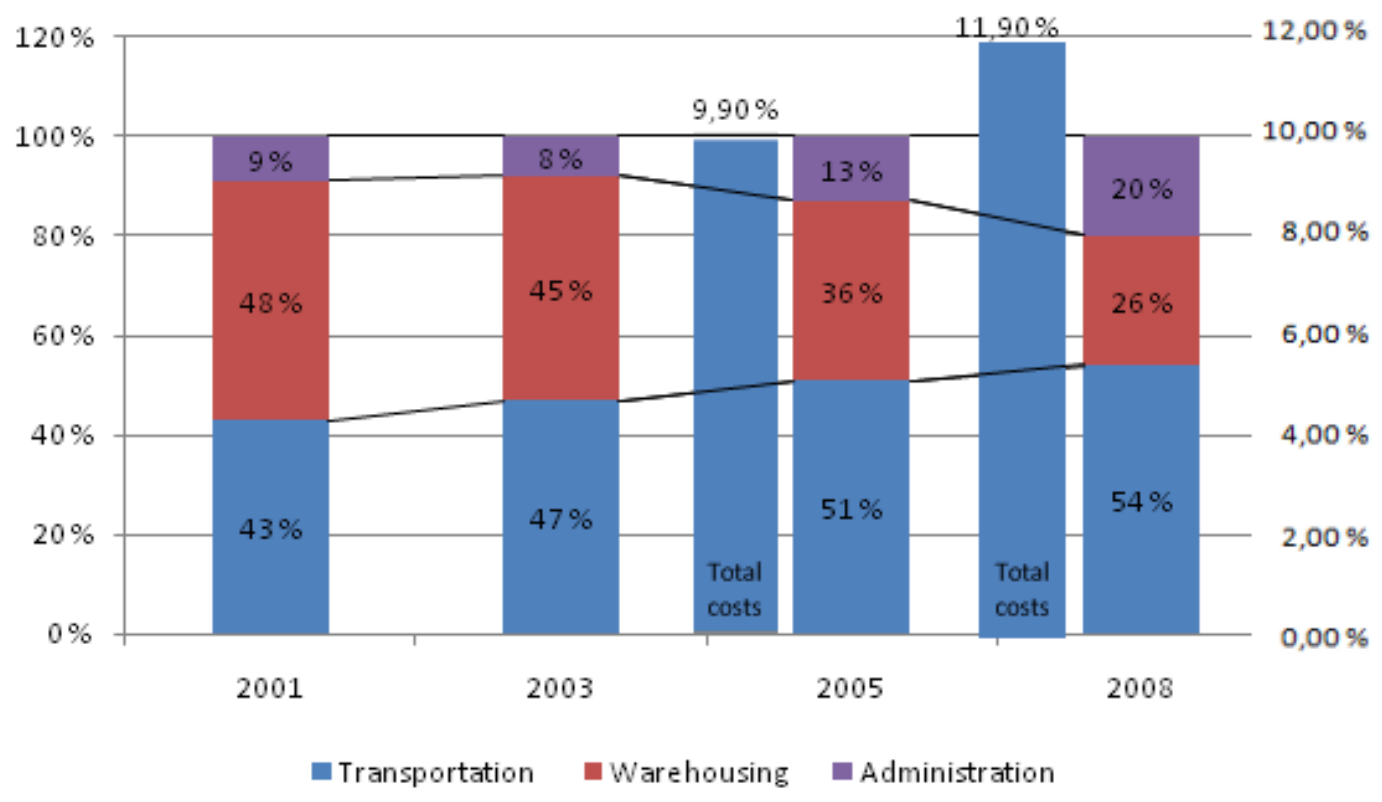

Source: ASLOG - L'etat de l'art de la Locistisque Française 2010) 
Figure 28. Total Logistics Costs in Colombia, 2008, as a Percentage of Sales

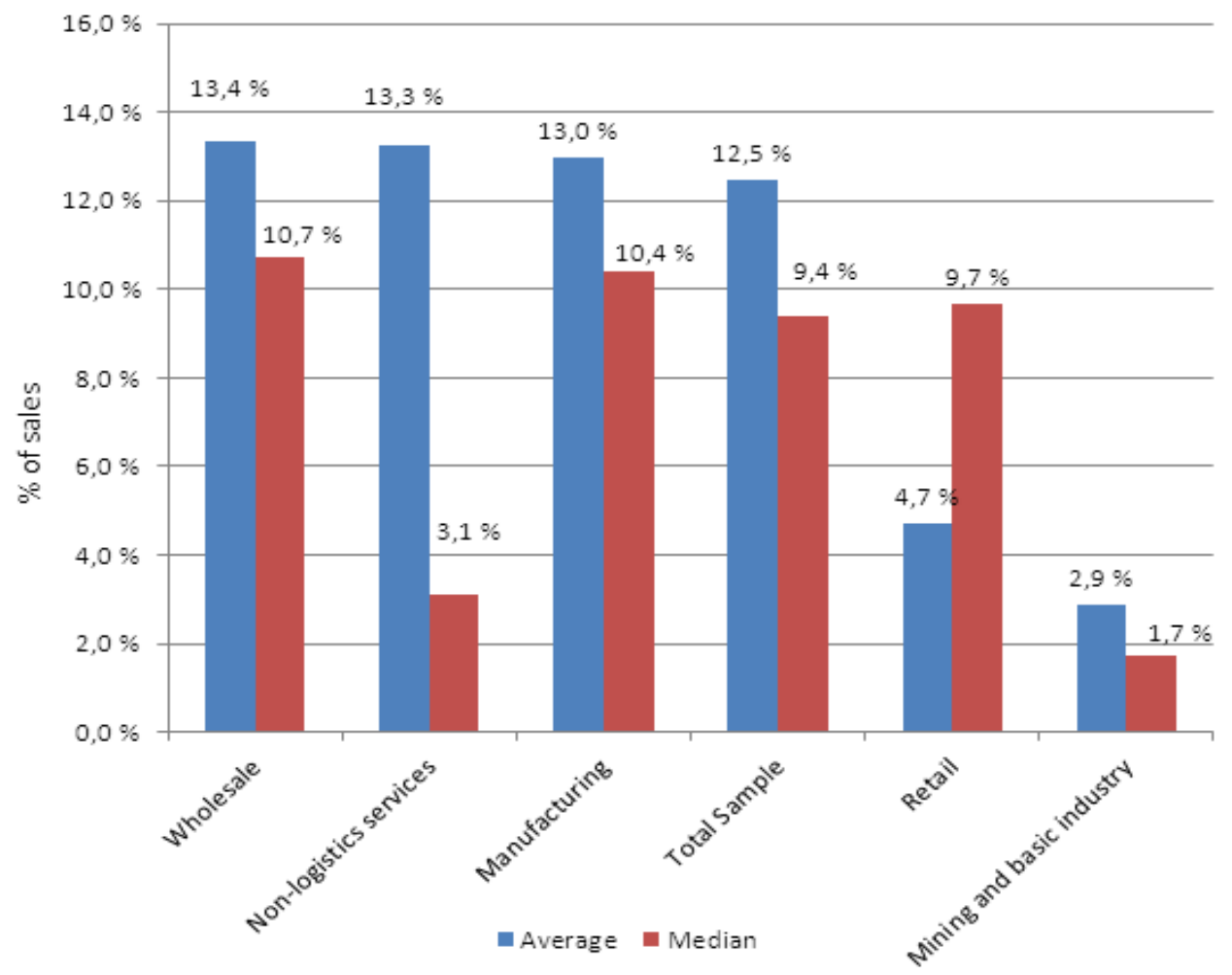

Source: Rey 2008, 93

Figure 29. The Development of Logistics Costs in Japan as a Percentage of GDP

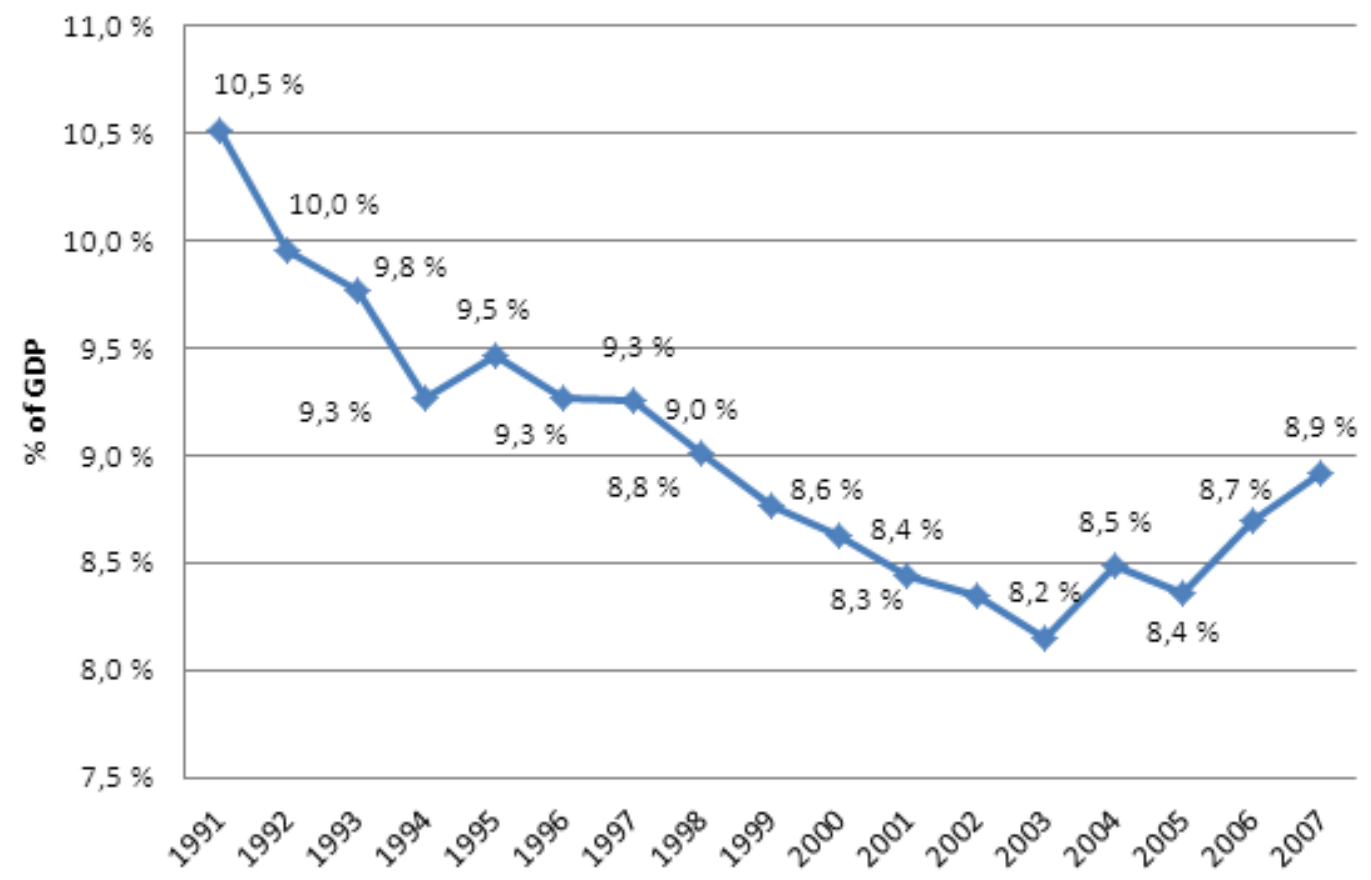

Source: JIL Database - Logistics Cost Data 
Figure 30. Logistics Costs in Latin America and Selected Developed Countries as a Percentage of GDP

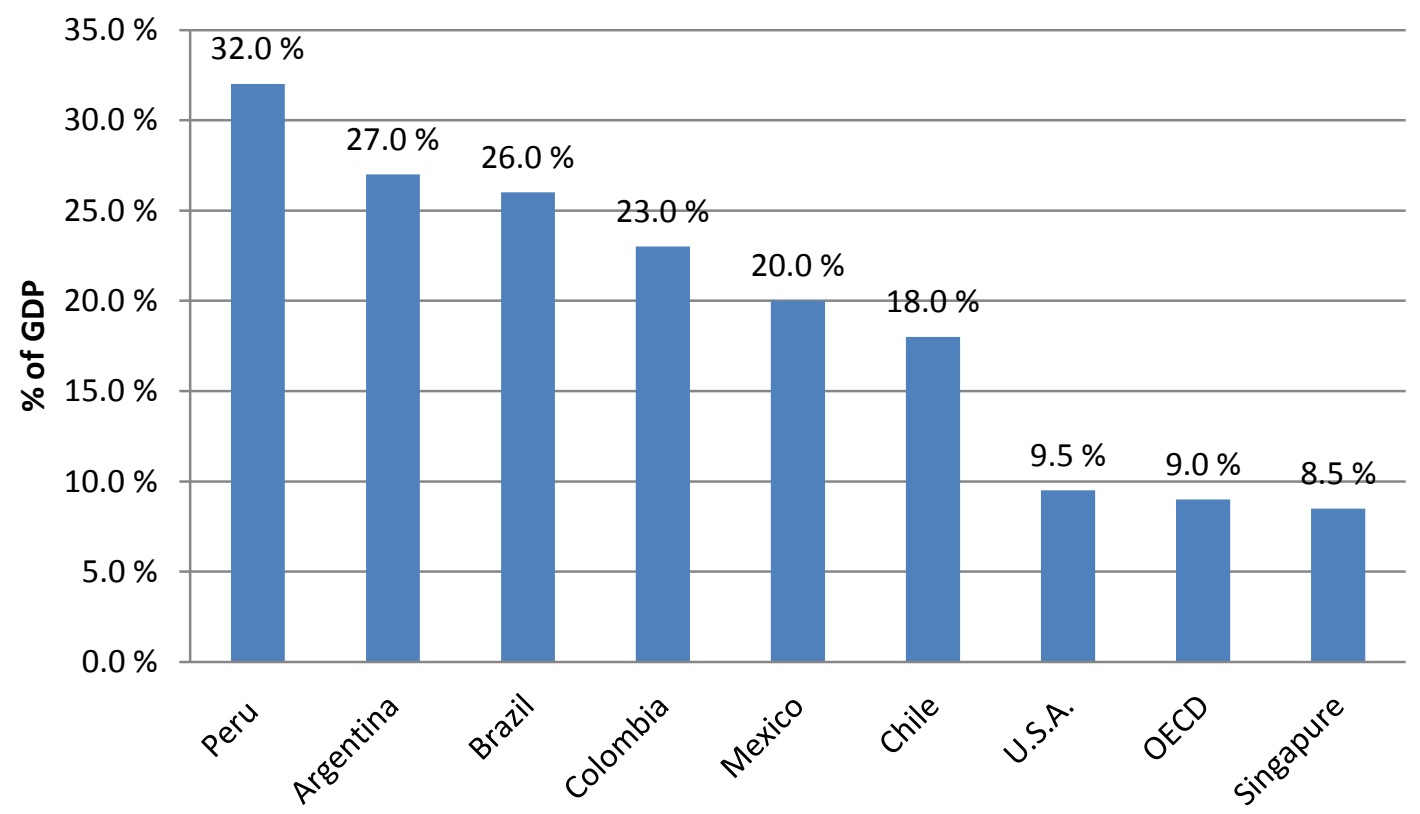

Source: Gonzalez et al. 2008, 10

Figure 31. Logistics Costs in Latin America, USA and the OECD Average as a Percentage of GDP, 2002 and 2004

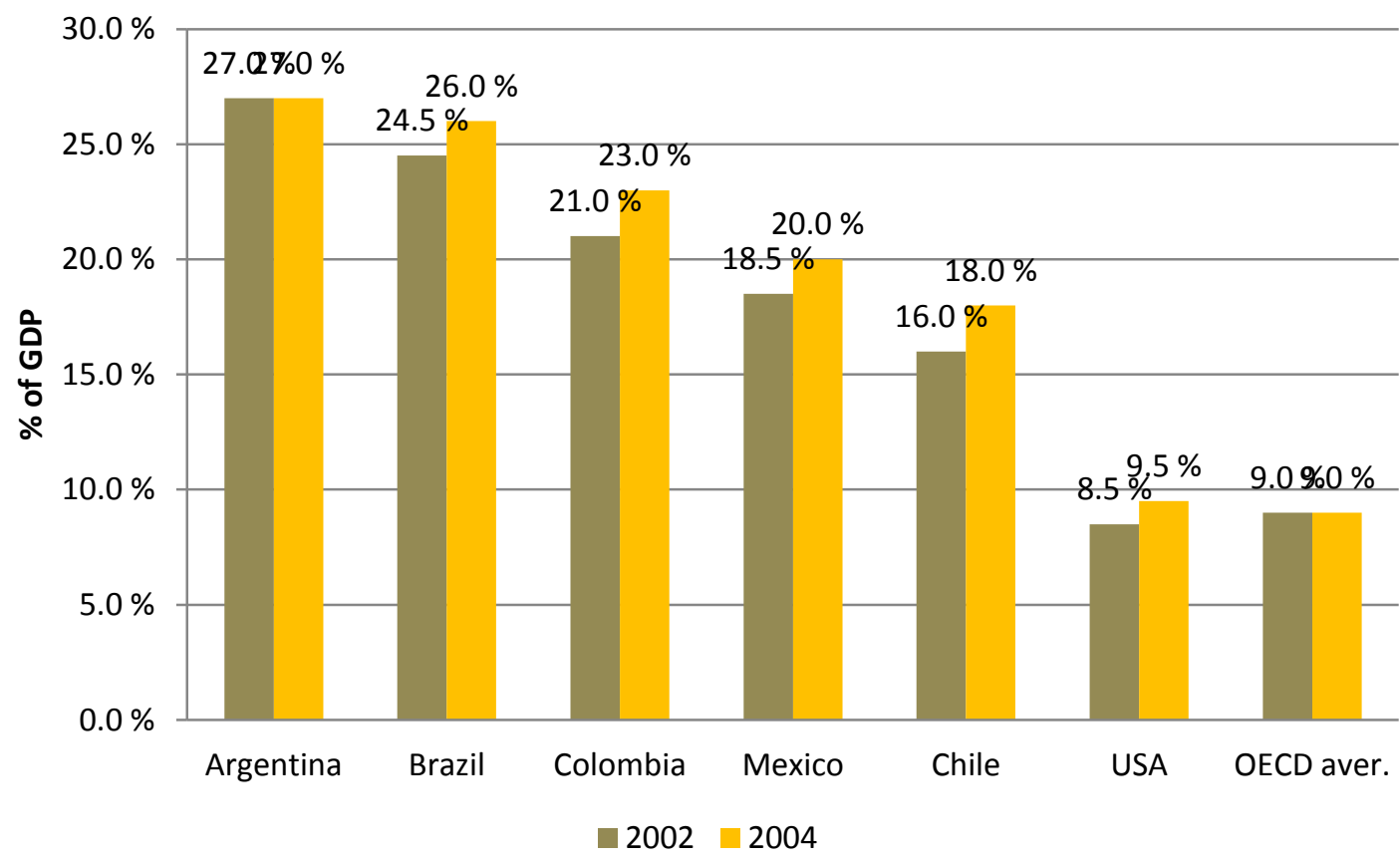

Source: World Bank reports 1 2006, 20-21; World Bank reports 2 2007, 8-9; Arvis et al., 9-10 
Table 7. Logistics Costs in Selected World Bank Studies

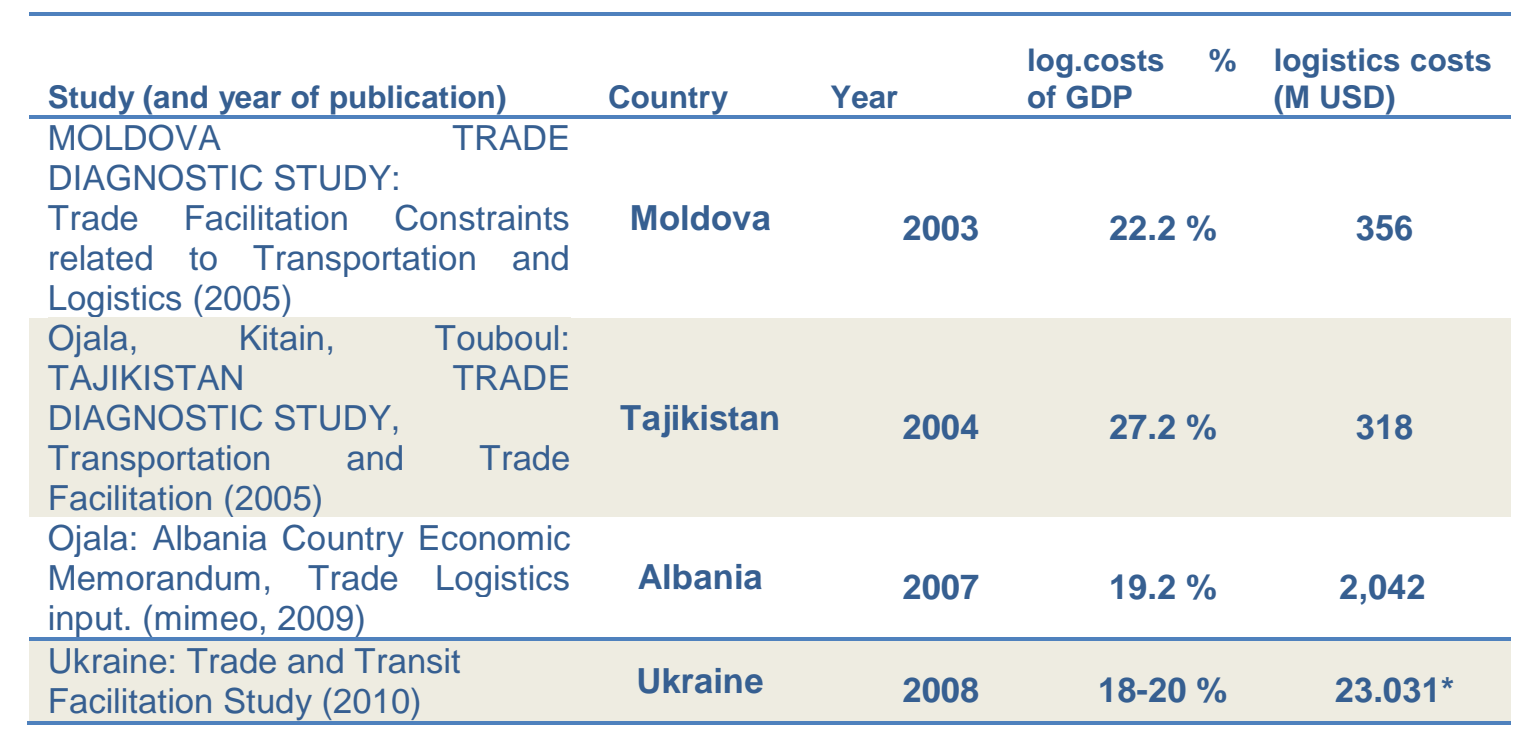

* costs related to foreign trade 
Table 8. Aggregated Cost Elements

\begin{tabular}{|c|c|c|c|c|c|c|c|}
\hline Literature & $\begin{array}{l}\text { 号 } \\
\text { ○ }\end{array}$ & Articles & $\begin{array}{l}\text { Ł } \\
\text { ᄋ̊ }\end{array}$ & $\begin{array}{c}\text { Statistics based } \\
\text { studies }\end{array}$ & $\begin{array}{l}\text { Ł } \\
\text { 엉 }\end{array}$ & Surveys & 占 \\
\hline Transportation & 8 & Transportation & 7 & Transportation & 7 & Transportation & 12 \\
\hline Inventory carrying & 7 & Warehousing & 5 & Administration & 5 & Warehousing & 12 \\
\hline Warehousing & 7 & Inventory carrying & 4 & Inventory carrying & 4 & Administration & 11 \\
\hline Packaging & 4 & Administration & 3 & Warehousing & 3 & Inventory carrying & 7 \\
\hline Administration & 2 & Risk and Damage & 3 & Cargo handling & 3 & Other & 5 \\
\hline Customer service & 2 & Insurance & 2 & Transport pack. & 2 & Transport pack. & 3 \\
\hline $\begin{array}{l}\text { Order processing / } \\
\text { information }\end{array}$ & 2 & Packaging & 2 & Communication & 2 & Insurance & 2 \\
\hline Associated labor & 1 & $\begin{array}{l}\text { Tied capital costs } \\
\text { (transportation) }\end{array}$ & 2 & Customer service & 2 & Obsolescence & 2 \\
\hline $\begin{array}{l}\text { Tied capital costs } \\
\text { (transportation) }\end{array}$ & 1 & $\begin{array}{l}\text { Cost of commodities } \\
\text { space movement }\end{array}$ & 1 & Documentation & 1 & $\begin{array}{l}\text { Customer service } \\
\text { /order entry }\end{array}$ & 2 \\
\hline Communication & 1 & Customer service & 1 & Equipment & 1 & Appraisal & 1 \\
\hline Consultancy & 1 & Customs & 1 & Information & 1 & Cost of capital & 1 \\
\hline $\begin{array}{l}\text { Cost of damaged } \\
\text { during transit }\end{array}$ & 1 & $\begin{array}{l}\text { Design, restructure } \\
\text { and option cost }\end{array}$ & 1 & Insurance & 1 & Customs & 1 \\
\hline Fixed costs & 1 & Forecasting & 1 & Internal logistics costs & 1 & Damages & 1 \\
\hline $\begin{array}{l}\text { Logistics } \\
\text { technology }\end{array}$ & 1 & Cargo handling & 1 & Internal services & 1 & Depreciation & 1 \\
\hline Lot quantity & 1 & Indirect logistics costs & 1 & Obsolescence & 1 & Delivery & 1 \\
\hline Manufacturing & 1 & Information & 1 & Outsourced logistics & 1 & Distribution centers & 1 \\
\hline Procurement & 1 & Order processing & 1 & Order processing & 1 & $\begin{array}{l}\text { Management/over } \\
\text { head }\end{array}$ & 1 \\
\hline $\begin{array}{l}\text { Purchased } \\
\text { materials }\end{array}$ & 1 & Other costs & 1 & Other costs & 1 & $\begin{array}{l}\text { Other indirect log. } \\
\text { costs }\end{array}$ & 1 \\
\hline Quality control & 1 & Permission losses & 1 & Plan/management & 1 & Shipper related & 1 \\
\hline Recycling logistics & 1 & Procurement & 1 & $R \& D$ & 1 & SUM & 66 \\
\hline Reverse logistics & 1 & $\begin{array}{l}\text { Substance } \\
\text { consumption }\end{array}$ & 1 & Shipper related & 1 & & \\
\hline Stock-out costs & 1 & Returned goods & 1 & SUM & 41 & & \\
\hline Trade costs & 1 & $\begin{array}{l}\text { Wages, bonus, } \\
\text { allowance }\end{array}$ & 1 & & & & \\
\hline $\begin{array}{l}\text { Value-added } \\
\text { services }\end{array}$ & 1 & SUM & 43 & & & & \\
\hline SUM & 49 & & & & & & \\
\hline
\end{tabular}


